\title{
Hanford Site Long-Term Surface Barrier Development Program: Fiscal Year 1994 Highlights
}
K. L. Petersen
S. O. Link
G. W. Gee

August 1995

Prepared for the U.S. Department of Energy

Contract DE-AC06-76RLO 1830

Pacific Northwest Laboratory

Operated for the U.S. Department of Energy by Battelle Memorial Institute 


\section{DISCLAIMER}

Portions of this document may be illegible in electronic image products. Images are produced from the best available original document. 
PNL-10605

UC-702

\title{
Hanford Site Long-Term Surface Barrier Development Program: Fiscal Year 1994 Highlights
}

\author{
K. L. Petersen \\ S. O. Link \\ G. W. Gee
}

August 1995

Prepared for

the U.S. Department of Energy.

under Contract DE-AC06-76RLO 1830

Pacific Northwest Laboratory

Richland, Washington 99352

DISTRIBUTION OF THIS DOCUMENT IS UNLIMITED

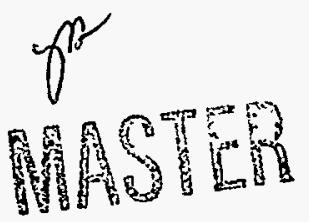




\section{Executive Summary}

The Hanford Site Surface Barrier Development Program was organized in 1985 to test the effectiveness of various barrier designs in minimizing the effects of water infiltration; plant, animal and human intrusion; and wind and water erosion on buried wastes, plus preventing or minimizing the emanation of noxious gases. A team of scientists from the Pacific Northwest Laboratory (PNL) and engineers from Westinghouse Hanford Company (WHC) direct the barrier development effort. ICF Kaiser Hanford Company, in conjunction with WHC and PNL, developed design drawings and construction specifications for a 5-acre prototype barrier.

The highlight of efforts in FY 1994 was the construction of the prototype barrier. The prototype barrier was constructed on the Hanford Site at the 200 BP-1 Operable Unit of the 200 East Area. Construction was completed in August 1994 and monitoring instruments are being installed so experiments on the prototype barrier can begin in FY 1995. The purpose of the prototype barrier is to provide insights and experience with issues regarding barrier design, construction, and performance that have not been possible with individual tests and experiments conducted to date. Additional knowledge and experience was gained in FY 1994 on erosion control, physical stability, water infiltration control, model testing, Resource Conservation and Recovery Act (RCRA) comparisons, biointrusion control, long-term performance, and technology transfer.

The barrier is designed to control water by partitioning it into runoff and temporary storage. Evapotranspiration will return stored water to the atmosphere. A capillary break created by the interface of the fine soil layer and coarser textured materials below will further limit the downward migration of surface water. Low-permeability asphalt layers, placed below the capillary break, will be used to divert water away from the waste zone should any water get through the capillary break. Tested barrier designs appear to work adequately to prevent drainage under current and postulated wetter climate conditions. The prototype barrier allows this design to be assessed in an integrated test.

Wind erosion will be minimized with a pea-gravel admix soil and vegetation. Wind erosion monitoring was initiated on the prototype barrier in August 1994. Water erosion studies were initiated in August 1994 to evaluate the effectiveness of the admix and vegetation in stabilizing the soil surface under natural rainfall and snowmelt conditions.

Physically disruptive forces that could occur during the +1000 -year design life of the Hanford Protective Barrier are being assessed. These include tornadoes, high winds, high-intensity precipitation, earthquakes, and volcanic ash deposition.

Water infiltration control tests were done at the Field Lysimeter Test Facility (FLTF). Tests at the FLTF continue to show the advantages of using silt loam soil as a surface material. Silt loam soil has the largest storage capacity of any material tested. When incorporated in a capillary barrier design, this material is capable of storing at least three times the annual average precipitation before drainage occurs. For vegetated, silt-loam surfaces, there has never been any drainage since testing began, even under the most extreme climate regime tested (i.e., $480 \mathrm{~mm} / \mathrm{yr}$ precipitation, three times the annual average). Tests with bare silt loam surfaces have shown that under the extreme climate. 
conditions, modest amounts of drainage have occurred over the past 2 years. For ambient treatments, there has not been any drainage from silt loam soils under any treatment. When vegetation is present, barriers at Hanford with silt-loam surfaces are not expected to drain.

An asphalt layer is an important component of the barrier. This layer provides a RCRAequivalent backup to the overlying earthen layers in the unlikely event these layers cannot prevent drainage. Studies were done on RCRA equivalency, physical properties, aging characteristics, and ancient asphalt analogs.

Simulation models of the hydrology of protective barriers were compared to evaluate their performance for a minimum of 1000 years. The UNSAT-H code was compared with the EPA's HELP code, with the conclusion that the HELP code is inadequate for Hanford conditions.

RCRA equivalency of the Hanford Protective Barrier is being tested at Hill Air Force Base near Ogen, Utah. The use of an existing lysimeter facility simplifies construction and allows comparison of the Hanford Protective Barrier with an existing clay cap at the site. The clay cap was designed to meet EPA-RCRA guidelines. This site also allows testing in a wetter and colder environment, similar to the upper bound of predicted climate change at Hanford in the next +1000 years.

Plant studies focused on efforts to revegetate the prototype surface. Seeds of native shrubs were collected at McGee Ranch in December 1994. Seedlings were grown for transplanting onto the prototype barrier's surface.

Climate change studies indicate that the long-term mean annual precipitation in the Columbia River Basin is estimated to have ranged between $50 \%$ to $75 \%$ of modern and $130 \%$ of modern levels, while temperatures have ranged from $7^{\circ} \mathrm{C}$ to $10^{\circ} \mathrm{C}$ below to $2^{\circ} \mathrm{C}$ above modern levels. There is no evidence that the long-term precipitation averages ever reached three times that of present. Such climatic records and extreme value analysis suggest that climatic cycles for at least 1000 years into the future should also be bounded by the three times normal precipitation limit and limited to a daily precipitation maximum of about $70 \mathrm{~mm}$ at the Hanford Site.

Technology transfer efforts have centered on publishing and distributing research information. Documents produced throughout barrier development activities continue to be published and provided to interested individuals and organizations both onsite and offsite. Over 90 barrier-related documents have been published so far.

The completion of FY 1994 marks a transition point for the program; one in which the functional principles upon which the design of the long-term surface barrier is based have been shown technically sound. With the completion of the prototype barrier, full-scale performance issues can be addressed to ensure technical suitability, public confidence, and regulatory acceptance of the barrier for the long-term isolation of hazardous and nuclear contaminants. 


\section{Acronyms}

BDP Barrier Development Program

BDT Barrier Development Team

BHI Bechtel Hanford, Inc.

DOE U.S. Department of Energy

EM electromagnetic induction

EPA U.S. Environmental Protection Agency.

FHP falling head permeameter

FLTF Field Lysimeter Test Facility

FY fiscal year

GPR ground-penetrating radar

HPLC high-pressure liquid chromatography

IR infrared spectroscopy

IRDS information resource dictionary system

Kaiser ICF Kaiser Hanford Company

LANL Los Alamos National Laboratory

LMS large molecular size

MRL Materials Reference Library

PNL Pacific Northwest Laboratory

RCRA Resource Conservation and Recovery Act of 1976

RDBMS relational database management system 
RMS root mean square

SDRI sealed double ring infiltrometer

SEC size exclusion chromatography

SHRP Strategic Highway Research Program

TDR time domain reflectometery

UC ultraviolet

WHC Westinghouse Hanford Company 


\section{Acknowledgments}

Funding was provided by the Office of Environmental Restoration of the U.S. Department of Energy under Contract DE-AC06-76RLO 1830 (Pacific Northwest Laboratory) and Contract DE-AC06-87RL10930 (Westinghouse Hanford Company).

Pacific Northwest Laboratory is operated by Battelle Memorial Institute for the U.S. Department of Energy under Contract DE-AC06-76RLO 1830. 



\section{Contents}

Executive Summary $\ldots \ldots \ldots \ldots \ldots \ldots \ldots \ldots \ldots \ldots \ldots \ldots \ldots \ldots \ldots$ iii

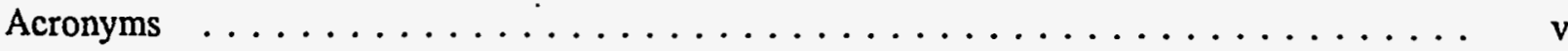

Acknowledgments $\ldots \ldots \ldots \ldots \ldots \ldots \ldots \ldots \ldots \ldots \ldots \ldots \ldots \ldots \ldots$ vii

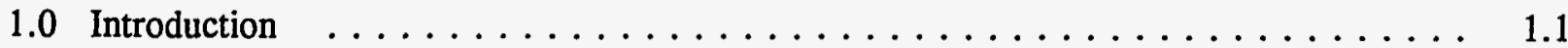

1.1 Need for A Long-Term Barrier $\ldots \ldots \ldots \ldots \ldots \ldots \ldots \ldots$

1.2 Organization of the Surface Barrier Development Program $\ldots \ldots \ldots \ldots \ldots$

1.3 Functional Performance of Long-Term Surface Barriers . . . . . . . . . . . 1.3

1.4 Document Organization $\ldots \ldots \ldots \ldots \ldots \ldots \ldots \ldots \ldots \ldots \ldots$

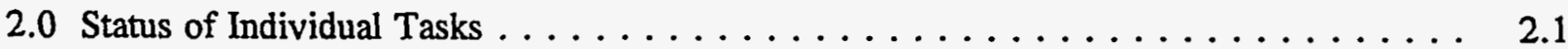

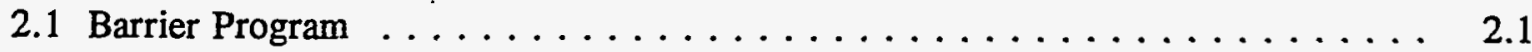

2.1 .1 Peer Review $\ldots \ldots \ldots \ldots \ldots \ldots \ldots \ldots \ldots \ldots \ldots \ldots \ldots \ldots$

2.1.2 Design Basis Document $\ldots \ldots \ldots \ldots \ldots \ldots \ldots \ldots \ldots \ldots \ldots$

2.1.3 Protective Barrier Prototype Database . . . . . . . . . . . . 2.2

2.2 Prototype Surface Barrier $\ldots \ldots \ldots \ldots \ldots \ldots \ldots \ldots \ldots \ldots \ldots \ldots \ldots$

2.2.1 Wind Erosion $\ldots \ldots \ldots \ldots \ldots \ldots \ldots \ldots \ldots \ldots \ldots \ldots \ldots \ldots \ldots$

2.2.2 Water Erosion $\ldots \ldots \ldots \ldots \ldots \ldots \ldots \ldots \ldots \ldots \ldots \ldots \ldots$

2.2.3 Biointrusion and Revegetation $\ldots \ldots \ldots \ldots \ldots \ldots \ldots \ldots \ldots$

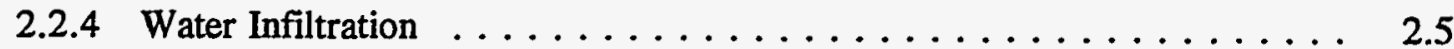

2.3 Erosion and Deposition Control $\ldots \ldots \ldots \ldots \ldots \ldots \ldots \ldots \ldots \ldots$

2.3.1 Wind Erosion $\ldots \ldots \ldots \ldots \ldots \ldots \ldots \ldots \ldots \ldots \ldots \ldots \ldots \ldots$

2.3 .2 Water Erosion $\ldots \ldots \ldots \ldots \ldots \ldots \ldots \ldots \ldots \ldots \ldots \ldots \ldots$

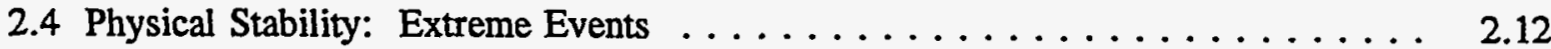


2.4.1 Assessment of Potentially Disruptive Natural Events . . . . . . . . . 2.12

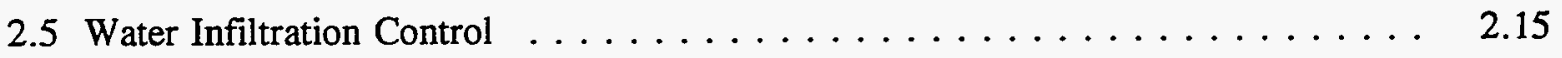

2.5.1 Field Lysimeter Test Facility . . . . . . . . . . . . . 2.15

2.5 .2 Asphalt Technology . . . . . . . . . . . . . . . . . 2.19

2.5 .3 Asphalt Analog Studies . . . . . . . . . . . . . . 2.22

2.6 Model Applications and Testing . . . . . . . . . . . . . . . . 2.29

2.7 Resource Conservation and Recovery Act Comparisons . . . . . . . . . . 2.32

2.7.1 Experimental Plan and Construction Guidance for Hanford Protective Barrier Test in A Wetter, Colder Climate at Hill Air Force Base, Utah . . 2.32

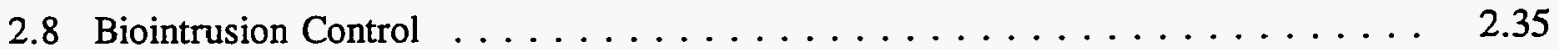

2.8.1 Establishment of Vegetation on the Prototype Surface $\ldots \ldots \ldots \ldots$

2.8.2 Root Characteristics of the FLTF Lysimeters . . . . . . . . . . . 2.36

2.9 Long-Term Performance $\ldots \ldots \ldots \ldots \ldots \ldots \ldots \ldots \ldots \ldots$

2.9 .1 Climate Change $\ldots \ldots \ldots \ldots \ldots \ldots \ldots \ldots \ldots \ldots \ldots$

2.9 .2 Natural Analogs . . . . . . . . . . . . . . . . . 2.38

2.10 Technology Transfer $\ldots \ldots \ldots \ldots \ldots \ldots \ldots \ldots \ldots \ldots \ldots$

2.10.1 Technology Integration and Transfer $\ldots \ldots \ldots \ldots \ldots \ldots . \ldots . . \ldots . . \ldots$

2.10.2 Barrier Development Program Documentation . . . . . . . . . . 2.39

2.10 .3 Videotape Production $\ldots \ldots \ldots \ldots \ldots \ldots \ldots \ldots \ldots \ldots$

2.10.4 Consultation on Barrier-Related Topics $\ldots \ldots \ldots \ldots \ldots$

2.10 .5 Technology Transfer $\ldots \ldots \ldots \ldots \ldots \ldots \ldots \ldots \ldots \ldots \ldots . \ldots \ldots$

3.0 References $\quad \ldots \ldots \ldots \ldots \ldots \ldots \ldots \ldots \ldots \ldots \ldots \ldots \ldots \ldots \ldots \ldots \ldots \ldots$

Appendix A - Supporting Letters From Dr. David Daniel $\ldots \ldots \ldots \ldots \ldots \ldots$

Appendix B - Permanent Isolation Surface Barrier Documents $\ldots \ldots \ldots \ldots \ldots$. . . . B.1 


\section{Figures}

1.1 Typical Isolation Barrier $\ldots \ldots \ldots \ldots \ldots \ldots \ldots \ldots \ldots \ldots \ldots \ldots \ldots \ldots$

2.1 Layout of Barrier Surface Grid and Monitoring System $\ldots \ldots \ldots \ldots \ldots \ldots$

2.2 Treatment Description of the Field Lysimeter Test Facility, September $1994 \ldots \ldots \ldots \ldots \ldots \ldots \ldots \ldots \ldots \ldots \ldots \ldots \ldots . \ldots \ldots$

2.3 Drainage from Small Tube Lysimeters Through July $1994 \ldots \ldots \ldots \ldots \ldots \ldots$

2:4 Field Falling Head Permeameter Used for Prototype Measurements . . . . . . . . 2.20

2.5 Qualitative IR Spectra of A) Monterey Pine Pitch and

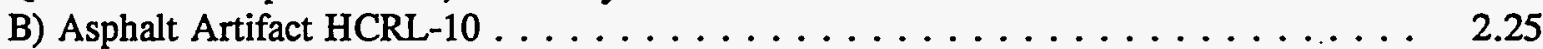

2.6 HPLC-SEC Plots Illustrating the Change in the LMS Region for A) Artifact Sample HCRL-14 (4160 BP +/- 100 Years), B) Artifact Sample HCRL-10 (1510BP $+/-60$ Years), and C) Analog Sample Analog-9 . . . . . . . . 2.27

2.7 Plot of Area Percent of the LMS for Asphalt Artifacts as a Function of Age of Internment, as Determined by Radiocarbon Dating . . . . . . . . . 2.28

2.8 Comparison of Measured Suctions and Suctions Simulated with UNSAT-H Using Either Standard Parameters or Hysteresis $\ldots \ldots \ldots \ldots \ldots \ldots \ldots \ldots 2.30$

2.9 Comparison of Measured and Simulated Suctions and Drainage $\ldots \ldots \ldots \ldots 2.31$

2.10 Location of Hill Air Force Base $\ldots \ldots \ldots \ldots \ldots \ldots \ldots \ldots \ldots \ldots . \ldots \ldots$

2.11 Staggered Cross Section of Lysimeter Located at Hill Air Force Base, Utah $\ldots . \ldots .2 .34$

2.12 Perspective View of the Hanford Barrier Lysimeter and Existing Lysimeters at the Hill Air Force Base, Utah $\ldots \ldots \ldots \ldots \ldots \ldots \ldots \ldots \ldots \ldots \ldots \ldots \ldots \ldots \ldots .34$ 


\section{Tables}

2.1 Hydraulic Conductivity of Hot-Mixed Asphalt Concrete Layer of Prototype

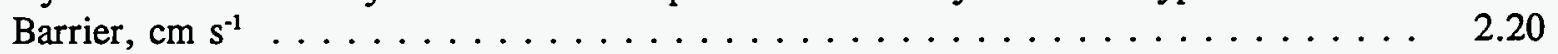

2.2 Summary of Hydraulic Conductivity Data for Prototype Hot-Mixed Asphalt Concrete Cores ......................... 2.21

2.3 Hydraulic Conductivity of Polymer-Modified Asphalt Membrane Samples from Prototype Barrier . . . . . . . . . . . . . . . . . . 2.21

2.4 Radiocarbon Dates of Chumash Artifacts $\ldots \ldots \ldots \ldots \ldots \ldots \ldots \ldots \ldots \ldots$

2.5 Elemental Analysis of Asphalt Analog and Artifact Samples . . . . . . . . . . . 2.24

2.6 Summary Statistics of Model Comparisons $\ldots \ldots \ldots \ldots \ldots \ldots$

2.7 Oven-Dried Root Biomass Density $\left(\mathrm{mg} \mathrm{cm}^{-3}\right)$ in the FLTF Lysimeters $\ldots \ldots \ldots$ 


\subsection{Introduction - N. Richard Wing (IT Hanford, Inc.)}

Surface barriers are being developed at the U.S. Department of Energy's (DOE) Hanford Site near Richland, Washington, to isolate and dispose of buried wastes for extremely long time periods. Existing short-term barrier designs, such as the covers recommended by the U.S. Environmental Protection Agency (EPA) for remediating waste sites under the purview of the Resource Conservation and Recovery Act of 1976 (RCRA), are not adequate for isolating many of the wastes to be disposed of at the Hanford Site because of their short design life and high failure rate (Daniel 1994).

\subsection{Need for A Long-Term Barrier}

Generally, the design life of RCRA covers is relatively short (e.g., the 30-year postclosure period specified by RCRA). Barrier performance during this short period can be monitored, and maintenance activities can be performed to correct any problems encountered. However, some wastes at Hanford will need to be isolated for much longer periods (i.e., centuries to millennia). In these cases, the relatively short-term (i.e., RCRA) designs probably will not be satisfactory. For example, many synthetic construction materials that might be effective for decades, such as geosynthetics, cannot be relied on to perform satisfactorily or even exist for more than 1000 years. In addition, compacted clay layers have been demonstrated to desiccate and crack in arid environments such as at the Hanford Site. Consequently, a long-term surface barrier is needed.

Long-term surface barriers have been identified as integral components in the final disposal schemes for the near-surface disposal of these wastes:

- single-shell tank wastes

- transuranic-contaminated soil sites
- suspect transuranic-contaminated solid wastes buried before 1970 .

In addition, other forms of waste may require long-term surface barriers, including decommissioned facilities, solid waste sites, lowlevel waste sites, and hazardous waste sites. Also, long-term surface barriers probably will be needed for the proposed large-scale remediation approach to cleaning up the Hanford Site.

\subsection{Organization of the Surface Barrier Development Program}

The Hanford Site Surface Barrier Development Program (BDP) was organized in 1985 to develop, test, and evaluate the effectiveness of various barrier designs. A team of engineers and scientists from Westinghouse Hanford Company (WHC) ${ }^{(a)}$ and the Pacific Northwest Laboratory (PNL) has been directing the barrier development effort. ICF Kaiser Hanford Company (Kaiser) has provided design support for barrier-related projects. Most recently, Kaiser, in conjunction with WHC and PNL,

(a) In July 1994, an Environmental Restoration Contract was awarded to a team of contractors led by Bechtel Hanford, Inc., (BHI). The barrier development work previously performed by WHC employees was transferred to IT Hanford, Inc., one of the pre-selected contractors to BHI. 
developed the definitive design drawings and construction specifications for a 5-acre prototype barrier. Construction of the prototype barrier began in late 1993 and was completed in August 1994.

The objective of current designs is to develop a long-term surface barrier with the following features:

- functions in a semiarid to subhumid climate

- limits the recharge of water through the waste to the water table to near-zero amounts $(0.05 \mathrm{~cm}$ of water per year [ 1.6 by $10^{9} \mathrm{~cm} / \mathrm{s}$ ] was the design objective selected, based on preliminary performance assessments)

- is maintenance free

- minimizes the likelihood of plant, animal, and human intrusion

- limits the exhalation of noxious gases

- minimizes erosion-related problems

- meets or exceeds RCRA cover performance requirements

- isolates wastes for a minimum of 1000 years

- is acceptable to regulatory agencies and the public.

Fifteen groups of tasks, listed below, have been organized to provide technically defensible evidence that final barrier design(s) will meet these performance objectives

(Wing 1994).
1. Project management

2. Biointrusion control

3. Water infiltration control

4. Erosion/deposition control

5. Physical stability testing

6. Human interference control

7. Procurement of barrier construction materials

8. Prototype barrier designs and testing

9. Model applications and validation

10. Natural analog studies

11. Long-term climate change effects

12. Interface with regulatory agencies

13. RCRA equivalency

14. Technology integration and transfer

15. Final design.

Specific test plans and other detailed documents have been or are being prepared to plan, schedule, execute, and report on each of the technology development activities within these task groups. The results of completed tasks are documented and used 1) as input to other tasks whose activities are dependent upon the results, 2) to improve computer simulation models, and 3) to develop detailed, final barrier designs. 


\subsection{Functional Performance of Long-Term Surface Barriers}

The surface barrier design consists of a fine-soil layer overlying other layers of coarser materials such as sands, gravels, and basalt riprap (Figure 1.1). Each of these layers serves a distinct purpose. The fine-soil layer acts as a medium in which moisture is stored until the processes of evaporation and transpiration recycle any excess water back to the atmosphere. This layer also provides the medium for establishing plants that are necessary for transpiration to take place. The coarser materials placed directly below the fine-soil layer create a capillary break that inhibits the downward percolation of water through the barrier. The placement of the silt loam directly over the underlying coarser materials also creates an environment that encourages plants and animals to limit their natural biological activities to the upper, fine-soil portion of the barrier, thereby reducing biointrusion into the lower layers. The coarser materials also will help deter inadvertent human intruders from digging deeper into the barrier profile. Low-permeability asphalt layers, placed in the barrier profile below the capillary break, also will be used in the protective barriers to 1) divert away from the waste zone any percolating water that gets through the capillary break, and 2) limit the upward movement of noxious gases from the waste zone. The coarse materials located above the low-permeability asphalt layers also serve as a drainage medium to channel any percolating water to the edges of the barrier.

Two side-slope configurations are being considered in long-term surface barrier designs: 1) a relatively flat apron of clean-fill materials (commonly called a clean-fill dike), and 2) a relatively steep embankment of fractured basalt riprap. The clean-fill dike concept uses readily available borrow materials (such as pitrun gravels) to create a relatively flat apron around the periphery of the barrier. This apron provides a more gentle transition from the shoulder of the barrier to the surrounding environment than does the steep side slope. The steep side-slope design uses fractured basalt riprap, which consists of relatively large angular rocks. The angularity of the riprap provides many interlocking surfaces between adjacent rocks, which allows a relatively steep, yet stable, side slope to be created.

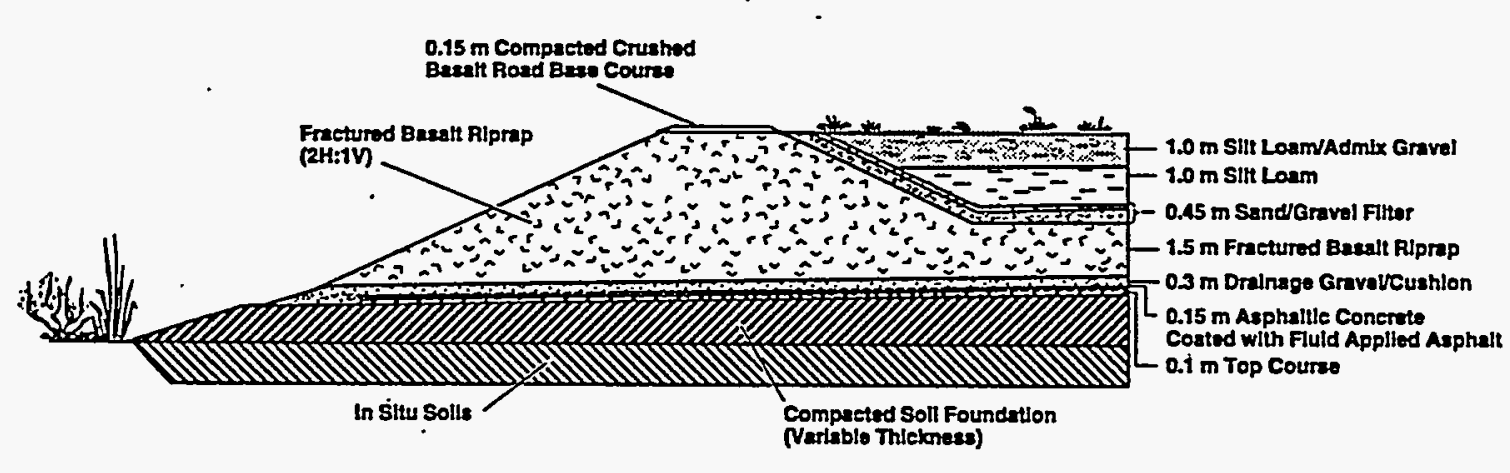

Figure 1.1. Typical Isolation Barrier 
The control of water infiltration at the periphery of the barrier is a significant design feature that must be considered for both clean-fill dike and fractured basalt side slopes. Protective barriers are designed with sloped fine-soil surfaces and low-permeability subsurface components. Consequently, water will be channeled to the side slopes and toe of the barrier. Because of this channeling, a significant amount of water is expected to accumulate at the periphery of the barrier. Water accumulation poses a major design consideration: How can the additional water be prevented from contacting buried wastes?

There are many approaches for controlling potential water infiltration problems at the side slope and toe of a surface barrier. Three key options being considered include 1) allowing an adequate amount of barrier overhang, 2) using vertical asphalt or grout curtains, and 3) designing the toe of the barrier to remove water passively via plant transpiration.

\subsection{Document Organization}

The next chapter summarizes the technical accomplishments of various barrier development tasks and activities conducted during fiscal year (FY) 1994. Chapter 3 lists the references cited. Appendix A provides copies of letters from an independent peer reviewer, and Appendix B lists all the publications associated with the BDP. 


\subsection{Status of Individual Tasks}

Permanent isolation surface barriers are being considered for use in disposal of certain types of waste at the Hanford Site and elsewhere. The BDP has been designed to address various technical issues associated with the performance of long-term surface barriers. All of the tasks conducted within the BDP have been designed to provide crucial information needed to address these technical issues.

Highlights from the following tasks and activities are provided in this chapter: barrier program, prototype surface barrier, erosion and deposition control, physical stability (extreme events), water infiltration control, model applications and testing, RCRA comparisons, biointrusion control, long-term performance, and technology transfer.

\subsection{Barrier Program}

\subsubsection{Peer Review - N. Richard Wing (IT Hanford, Inc.)}

During FY 1994, Dr. David E. Daniel, Professor of Civil Engineering at the University of Texas at Austin, was contracted as a barrier expert to provide technical oversight to the entire BDP and to the construction of the prototype barrier. Two letters summarizing Dr. Daniel's peer review of the BDP are provided in Appendix A.

\subsubsection{Design Basis Document - Dennis R. Myers (IT Hanford, Inc.)}

The Hanford Site Surface BDP was organized in 1985 to develop the technology needed to provide a long-term surface barrier capability for the Hanford Site and other arid sites. A Barrier Development Team (BDT) was established to develop, test, and evaluate the effectiveness of various barrier design configurations. The BDT identified 15 groups of tasks to resolve the technical concerns and complete the development and design of protective barriers for the Hanford Site. The major barrier development task groups are listed in Chapter 1.0.

The BDP is now ready to design and construct a prototype barrier that combines all the information and data generated by the task groups into a comprehensive, state-of-the-art barrier design for testing and monitoring. Although the results of development and testing efforts conducted previously are not final and additional work needs to be performed, enough information and data exist to allow the design and construction of a prototype barrier.

A full-scale prototype barrier enables engineers and scientists to gain insights and experience with issues regarding barrier design, construction, and performance that have not been possible with the individual tests and experiments conducted to date in the program.

The design of a prototype barrier was completed in 1993 and construction of the barrier was completed in 1994. Testing and monitoring of the prototype barrier is planned for a minimum of 3 years, beginning immediately after construction. 
The prototype barrier will be tested and monitored to evaluate its performance over a range of conditions representative of those expected during the design life of a long-term surface barrier. A number of tests and experiments will be conducted on the prototype barrier to assess its performance under the conditions of water infiltration, biointrusion, erosion, and degradation of physical stability. Because only a finite amount of time exists to test a prototype barrier that is intended to function for a minimum of 1000 years, the testing program has been designed to "stress" the prototype so barrier performance can be determined within a reasonable time frame. Other BDP elements (e.g., natural analogs, long-term climate change, modeling, etc.) provide data necessary to increase confidence in the longterm performance of the surface barrier.

The design basis document produced within this task provides the basis for the design of the prototype barrier (Myers and Duranceau 1994). To produce the design, engineers and scientists have momentarily "frozen" evolving barrier designs and incorporated the latest findings from BDP tasks. The design and construction of the prototype barrier has required that all of the various components of the barrier be integrated, a particularly important step because some of the barrier components have been developed independently of other barrier components. The design basis document serves as the "baseline" for comparing future modifications or other barrier designs. The document justifies why various materials were chosen in the design, why the various layers of the barrier look the way they do, and how the barrier's performance will be tested and monitored. It also discusses long-term barrier issues and concerns. The appendix contains 1 ) the minutes of meetings convened during the definitive design process in which critical decisions affecting the prototype barrier's design were made, 2) characterization data for physical properties of various key barrier construction materials, 3) construction drawings, 4) construction specifications, and 5) the construction quality assurance plan. Another complementary document that describes the lessons learned from the construction phase of the prototype barrier project will be prepared.

\subsubsection{Protective Barrier Prototype Database - S.K. Smith (PNL)}

Because the prototype barrier is being developed under a multi-disciplinary project, large amounts of data from diverse sources will be collected. The goal of the database task is to create a data repository for the collected data. The repository will include an information resource dictionary system (IRDS), an auxiliary database containing descriptions of the data. Auxiliary descriptive data are commonly called meta-data. These meta-data will allow researchers to understand the collected data in the detail required for their own interpretation. With the data and meta-data, researchers can create data sets that combine data from other tasks. As scientists interpret the data sets, the new interpreted data they create will be added to the data repository.

The data repository will consist of a central database and one or more replica databases. We have chosen Paradox as the relational database management system (RDBMS) for the central database. We will create a Paradox runtime front-end interface for accessing the database using the development tools available with Paradox. The central database interface 
will ease the creation of data sets. Any owner of Paradox will have native access to the database so they can use Paradox to its fullest capability.

We chose to use a relational system for managing this scientific data, even though relational systems are used primarily for business applications. A relational system is a good choice for this project because of its availability, flexibility, programming ease, power, and cost. Unlike typical business applications, we expect few changes to the actual data because we are collecting information about primarily quantitative physical phenomena at a point in time. There probably will be corrections as a result of errors in calibration or interpretation that are discovered after donation. On the other hand, the meta-data that are often qualitative will change as is necessary for a clearer definition of the data and collection practices. When the data and meta-data from the first year of monitoring are considered static, we will publish the database in CD-ROM form. We plan to publish a cumulative database each year of the barrier monitoring task.

\subsection{Prototype Surface Barrier - G.W. Gee, M.D. Campbell, M.W. Ligotke, W.H. Walters, and S.O. Link (PNL)}

A full-scale prototype surface barrier has been constructed on the Hanford Site at the 200 BP-1 Operable Unit of the 200 East Area. The construction was completed in August 1994 and testing and monitoring equipment are being installed so detailed experiments of the prototype barrier can be conducted in FY 1995. The purpose of the prototype barrier is to provide insights and experience with issues regarding barrier design, construction, and performance that have not been possible with individual tests and experiments conducted to date. A constructability report (DOE 1994) documenting the construction of the prototype barrier has been prepared for DOE by BHI. A testing and monitoring plan (Gee et al. 1993a) has been written and is being updated to describe specific tests that will be conducted in FY 1995. The following sections provide a brief summary of the types of tests planned for the prototype; subsequent sections of this report provide additional detailed information.

\subsubsection{Wind Erosion}

Testing and monitoring activities to generate data on the effects of eolian erosion on the prototype barrier surface were initiated immediately after the surface layer was constructed. Test equipment was prepared and tested earlier in the year to be sure the post-construction period could be monitored. Wind erosion monitoring during the post-construction period is important because wind erosion represents a "worst-case" surface condition. Data generated during the period will be compared to data from subsequent periods as the surface of the barrier ages (periods following surface settlement and consolidation, formation of protective raindrop-impact crusts, formation of a pea gravel armor, and establishment of vegetation). Samples were taken to determine the concentration and distribution of pea gravel in the surface layer of the barrier before surface consolidation, rainfall, and soil loss caused by wind. Subsequently, three wind storms occurred before the first significant rainfall. The wind storms were monitored using two boundarylayer wind stations and three multi-sensor sand saltation and dust trap stations. The stations are connected to data loggers (excluding the dust traps) and testing and monitoring is 
planned to be continuous so data can be generated during all high-intensity wind events.

Because of the potentially large volume of data to be generated, a threshold wind speed of $7.5 \mathrm{~m} / \mathrm{s}$ was selected to control the rate of data acquisition. Additional information on objectives and methods is described in Section 2.3.

\subsubsection{Water Erosion}

The water erosion monitoring plan consists of two distinct collection efforts: 1) the measurement of runoff and sediment yield from a $6-\mathrm{m} \times 15-\mathrm{m}$ flume installed on the soil surface (controlled area monitoring), and 2) the observation and documentation of the effects of precipitation over the much larger remaining soil surface (barrier-surface monitoring). Also, rock creep gauges installed in the riprap side slope will be monitored to detect any movement of the rock mass.

Time-varying data of overland runoff from rainfall and snowmelt events and sediment yield will be collected. The data will be used to analyze erosion from precipitation falling on the barrier surface and the corresponding changes in soil erosivity as the surface ages over the 3-year monitoring period. Surface soil elevation and properties (e.g., density and moisture content) will be monitored seasonally or annually. Changes to the surface, such as vegetation cover and animal burrowing, will be documented with surveying methods and photography.

\subsubsection{Biointrusion and Revegetation}

The effects of hydrology, water, and wind erosion on the prototype barrier will also be significantly affected by plants and animals. Studies of the biological component of the prototype barrier will include work on the initial revegetation of the surface; continued monitoring of the developing plant community; rooting depth and dispersion in the context of biointrusion potential; the role of plants in the hydrology of the surface and toe regions of the barrier; the role of plants in stabilizing the surface against water and wind erosion; and the role of burrowing animals in the hydrology, plant community dynamics, water, and wind erosion of the barrier (Link et al. 1994a).

The surface of the prototype barrier was revegetated in November 1994 after the fall rains began. The surface was hydroseeded with a variety of native grasses and forbs. The hydroseeding process includes applying fertilizer, mulch, and a tacking agent to secure the seeds to the surface. This material has been irrigated so the nutrients will move into the soil. Following the hydroseeding process, 10,000 seedlings of Artemisia tridentata and Chrysothamnus nauseosus were planted. Successful revegetation will lead to a perennial deeprooted native plant community on the surface. The surrounding areas will be hydroseeded with the native grass and forb mix.

The resulting plant community will be monitored during the year to document the success of the revegetation effort, invasion of alien species, the size and leaf area of the community, and transpiration rates.

Root biointrusion will be monitored with minirhizotrons. Twelve clear tubes will be drilled into the soil to the bottom of the siltloam soil layer to document rooting depth, root growth, and rooting density with depth. These tubes will be placed near neutron access ports so that root characteristics can be associated with soil water dynamics. The data collected 
will be useful in simulation modeling of plant transpiration on the surface.

Animals will colonize the barrier and burrow into the surface. The occurrence and effect of animal burrows on the prototype will be documented over the course of the observation period. Data will be collected three times a year and will include the date, burrow hole ID number, coordinate location, map location, animal species (if identifiable), hole diameter to nearest $0.5 \mathrm{~cm}$, photograph with $3 \times 5$ card showing hole ID number, and a description of cast soil at the surface (admix composition).

\subsubsection{Water Infiltration}

The prototype barrier is a unique facility for studying the water balance of a surface cover under both normal and stressed (extreme climate) conditions. Water will be applied to the north half of the barrier using irrigation and snow. Application rates will be similar to those used for testing Hanford covers at the Field Lysimeter Test Facility (FLTF). Plans call for application of water at the rate of $480 \mathrm{~mm} \mathrm{yr}^{-1}$ for the next 3 years on two test plots of the prototype barrier. The application will include irrigation on a biweekly basis except during winter. During winter, snow will be applied at rates of 3 times the normal snowfall $\left(130 \mathrm{~mm} \mathrm{yr}^{-1}\right)$. Thus, there will be three applications during the winter that will deliver $130 \mathrm{~mm}$ each time. The times for delivery will be weather dependent, but deliveries will occur between November and March each year. In late March of each year, irrigation will be delivered at a rate equivalent to a 1000 -year storm--i.e., $68 \mathrm{~mm}$ of irrigation delivered to the north side of the barrier over a 24-hour period.
The water balance of the barrier, under ambient and irrigated conditions, will be measured with a variety of instruments. Precipitation will be measured with a specially constructed mini-lysimeter that will act as a raingage and snowpillow combination, allowing measurement of both rainfall and snow with one instrument. Fourteen units will be used to measure the spatial distribution of the precipitation over the barrier surface. Snow depth will also be measured, both electronically and manually, with gauging instruments. Irrigation will also be measured with the mini-lysimeters.

A series of instruments will be used to measure soil water content and soil water storage. These instruments include neutronneutron devices, electrical capacitance instruments, and instruments for time domain reflectometry.

Neutron probe (neutron-neutron logs) will be used to measure the volumetric water content of the soil profile. The measurement will be converted to soil water storage data and the water storage compared as a function of irrigation treatment and time. Water content beneath the barrier (below the asphalt layer) and at the bottom of the soil layer (just above the soil/ sand interface) will also be measured. These monitoring points will be used to help determine the depth of water penetration in the barrier along selected transects. These data will also be useful in quantifying increases and decreases in storage associated with potential recharge (drainage) conditions. These instruments require manual operation and routine measurements (taken at least monthly). The neutron probe requires field calibration. Data from the lysimeters at the FLTF located in the 200 Plateau Area near the Hanford Meteorological Station will be used initially for water 
content estimates. Cores taken while installing the access tubes will be sampled for gravimetric water content and bulk density. These data will then be used to determine the volumetric water content of the soil. Neutron probe counts will be compared to the water contents and, subsequently, a calibration for the prototype barrier will be established. These data will then be compared to the FLTF calibration.

Electrical capacitance will also be used to measure volumetric water content. For this type of measurement, a commercially available capacitance probe will be used to log 2-m-deep soil profiles by lowering a cylindrical probe down small (5-cm-dia.) plastic access tubes. The electrical capacitance of a soil is dependent on both the sait and water content of the soil. If the salt content remains constant, the changes in capacitance can be calibrated in terms of the soil water content alone. The access tubes will be located adjacent to the neutron-probe access tubes. Capacitance will be calibrated by measuring water content and bulk density of the soil during coring and placement of the access tubes. Some additional water content and bulk density samples may be taken if the range of water contents obtained in the initial coring is not sufficient to cover the expected range of water contents.

Time domain reflectometry (TDR) (Hook et al. 1992) will also be used to measure volumetric water content in the soil profile. Time domain reflectometry uses an electronic pulse transmitted through the soil along a transmission cable and reflected back to a detector at a speed dependent on the dielectric properties of the soil. The dielectric constant of the soil is highly dependent on the soil water content. Because the dielectric constant for water is about 80 and for mineral soil, about 5 , the measured time for a reflected pulse can be uniquely related to the effective soil dielectric, which in turn is a measure of water content. The advantage of TDR over conventional neutron probe logging is that TDR can be automatically logged on virtually a continuous basis and the data collected remotely through electronic means. Further, there is no radioactivity, nor associated concerns regarding radiation safety.

A series of 15 TDR units will be installed. These units are specially constructed transmission rods containing shorting diodes. They permit measurements of water content across seven segments of a $185-\mathrm{cm}-\mathrm{long}$ rod buried vertically in the ground. The units will be connected, and by means of electronic switching all units will be logged at least daily. Thus, profiles of water content across the irrigated and nonirrigated (ambient) sections of the prototype will be displayed and documented. Both profiles and water storage (integrated profile data) will be stored in the data base. Weekly summaries of these data will be provided for review and analysis.

Thermal profiles will also be measured using copper-constantan thermocouples. Thermal heat dissipation units (Campbell and Gee 1986) will also be used to document the soil water suction. The temperature will be monitored hourly and the soil water suction monitored daily.

Noninvasive measures of water content planned for the prototype include the use of electromagnetic induction (EM) meters and ground-penetrating radar (GPR). Both methods are currently available and have been used for vadose zone characterization work at Hanford, primarily for detecting buried objects. However, the use of these systems for profiling 
water content in the vadose zone has not been evaluated. Because these devices offer a noninvasive method for characterization, they could be useful for routine monitoring of surface barriers at the Hanford Site and throughout the DOE complex. Collaboration with New Mexico Tech (Dr. Jan Hendrickx) is under way to develop an appropriate calibration for EM meters to monitor the surface of the prototype barrier for water content. When this work is completed, it should be possible to correlate the water content profiles obtained from neutron probes, capacitance probes, and TDR with the signal characteristics from both the EM meters and GPR units. Thus the prototype barrier, because of its well-defined surface features, will provide an excellent facility for calibrating noninvasive devices for monitoring water content profiles and evaluating water storage in surface barriers.

The prototype barrier will provide a unique test facility for measuring water balance parameters of surface barriers at Hanford. The facility will allow comparison of both intrusive and nonintrusive measures of soil water content and water storage, important and necessary parameters in evaluating surface barrier performance. Further, the barrier will be unique in that the drainage (recharge) that will come from the soil and the side slope surfaces under ambient and elevated precipitation (extreme event) conditions can be quantified. Such tests are necessary to evaluate long-term performance of surface barriers. Measures of recharge to levels of less than $0.05 \mathrm{~mm} \mathrm{yr}^{-1}$ are easily achievable with the large lysimeter system. In addition to water balance measurements, plant intrusion, wind erosion, and water erosion features will also be quantified during the 3-year test period.
A major contribution of water balance testing will be quality data (e.g., data on precipitation, water storage, drainage, runoff, etc.) that can be used for testing hydrologic models of surface water balance. Such modeling is critical to DOE in terms of providing estimates of long-term performance of surface barriers at Hanford. Barrier performance will be judged by estimated drainage rates and projections of long-term recharge. These projections will require computer models calibrated for Hanford Site conditions. The prototype barrier data set will be the only available data set for model validation in the country. The uniqueness of such a data set cannot be overemphasized. As the data are collected and carefully analyzed, they will be made available for site-wide use. It is also likely that the data set could become a standard set by which surface water balance models for other arid sites are compared and tested.

\subsection{Erosion and Deposition Control}

\subsubsection{Wind Erosion - M.W. Ligotke and G.W. Dennis (PNL)}

Maintaining an intact, erosion-resistant surface layer during periods of extended (dry) climatic stress is the goal of wind erosion studies performed in support of the development of a long-term, arid-land surface barrier. Reduced vegetative cover, caused by wildfires or by water deprivation during droughts, may expose the fine soil reservoir of the barrier to the scouring effects of wind and sand storms. In past years, wind tunnel studies were performed to study the formation and performance of natural surface armors under simulated stresses 
imparted by wind and saltating sand grains. These experiments provided design-basis information that contributed to the decision to construct a full-scale prototype barrier over the B57 waste crib (200 BP-1 Operable Unit, 200 East Area, Hanford) using a $15 \mathrm{wt} \%$ admixture of pea gravel in silt loam soil. The admixture was used in the top meter of the surface, covering another $1-\mathrm{m}$-thick layer consisting of only soil. .As part of a 3-year plan to test and monitor the prototype barrier, procedures were prepared, monitoring systems set up and tested, and stations installed on the surface of the prototype. Station installation was completed and data acquisition initiated in late August 1994, right after the barrier construction was completed.

Wind tunnel tests were performed previously to develop information on the use of coarse sands and gravels admixed with soil to form armors and reduce rates of eolian erosion during exposures to simulated extreme climatic stresses. (While the use of a thick surface cover of gravel would protect the soil layer from erosion, it would also enhance infiltration and potentially cause water to saturate and drain from the soil reservoir.) Results of the wind tunnel tests indicated that pea-gravel admixtures formed thin protective armors that protected soil from both wind and saltating sand stresses (Ligotke and Klopfer 1990, Ligotke 1993). In contrast, admixtures with coarse sand or larger sizes of gravel provided less or much less surface protection. Compared with rates of erosion from unprotected soil surfaces, pea gravel armors reduced soil loss by $93 \%$ at $15 \mathrm{~m} \mathrm{~s}^{-1}$ and by at least $96.5 \%$ to more than $99.4 \%$ at wind speeds of 20,25 , and $30 \mathrm{~m} \mathrm{~s}^{-1}$. Importantly, surface protection afforded by pea gravel also extended to applied stresses caused by saltating sand grains.
Exposed gravel armors absorbed the impact energy of saltating sand grains and resulted in deflation rates at least $45 \pm 6$ times less than those from unprotected surfaces.

Recommendations were made to validate wind tunnel studies by performing surface, wind, and saltating sand studies on the surface of a prototype barrier.

When the prototype barrier was completed in August 1994, monitoring of eolian erosion was initiated. Testing and monitoring objectives include work to 1) monitor the surface layer after construction and as it ages while exposed to natural conditions; 2) measure actual rates of surface deflation or inflation; 3) obtain micro-meteorological information about windcaused erosive shear stresses that affect the barrier, including the influence of the pile height and edge design on wind patterns; and 4) obtain information about the effect of abrasive sand particle scouring (saltation). In addition, two other activities have been proposed for the period starting in 1998: 1) create a sand dune and monitor its impact on surface erosion, plant community viability, and soil reservoir water balance; and 2) study erosive impacts after an artificial wildfire removes all surface vegetation. While the final two tasks would be valuable for identifying the effects of extreme climate and surface conditions, the potential for performing such tasks on a barrier covering an actual waste form is being evaluated. If necessary, the two tasks could be performed on a simulated barrier surface at an alternate site. Details of the testing and monitoring plan have been described by Gee et al. (1993a).

Work was initiated in FY 1994 to meet the first four testing and monitoring objectives. Two wind boundary layer stations were 
installed to monitor the structure of winds over the different regions of the prototype barrier surface. The resulting shear stresses will be determined from the characteristics of the vertical profile of wind over the surface. The stations include anemometers at elevations of $0.25,0.50,1.0$, and $2.0 \mathrm{~m}$, and sensors for wind direction, air temperature, and insolation. Surface moisture sensors are also being evaluated and may be added to the wind stations. The stations were connected to a single dedicated data logger, and software and reporting procedures were developed earlier in the year using an actual station. Although data acquisition is continuous, based on hourly averages, winds exceeding an operator-selectable threshold are monitored on a 10-minute cycle with the maximum 10-second peak gusts reported at all sensor elevations. The calibration of wind speed sensors was checked in a wind tunnel, and wind direction and sensor outputs were validated in the field.

In addition to the wind stations, 3 multisensor saltation stations were also installed on the eastern side of the southeast quadrant of the barrier surface. Earlier in the year, automated saltation sensors and dust traps were obtained and validated in a wind tunnel. The sensors, with cylindrical cross-sections to eliminate dependence on wind direction, provide a count record of sand grain impacts and a time record of the total kinetic energy of each erosion event. The dust traps, each with an attached wind vane, remain directed into the wind and collect physical samples of silt particles and sand grains. The three saltation stations provide triplicated data at an elevation of $0.25 \mathrm{~m}$, and additional data at $0.125,0.50$, and $1.0 \mathrm{~m}$ above the surface to provide data on the mass flow rate of soil and sand and the vertical distribution of wind-driven mass over the surface. A dedicated data logger is used to record data from the sensors. It is used to initiate data acquisition only during wind storms based on feedback from a wind speed sensor with a threshold setting currently at $7.5 \mathrm{~m} \mathrm{~s}^{-1}$. Dust traps are sampled manually after significant wind storm events.

Based on the results of wind tunnel tests, plans have been made to. optimize and validate the composition and performance of natural material erosion-resistant admixtures for longterm, arid-land waste site surface barriers. In FY 1994, work supported this goal as final planning was performed, instruments procured, sampling systems assembled, and data acquisition initiated at a completed prototype barrier. Baseline information regarding the condition and composition of the surface was obtained. Data files that included wind boundary layers, saltating sand drift potentials, and dust/sand surface mass fluxes were generated. Data acquisition, analysis, and interpretation is planned to continue as the barrier ages over a 3-year period.

\subsubsection{Water Erosion - W.H. Walters and B.G. Gilmore (PNL)}

Work conducted within the water erosion task during FY 1994 included developing and implementing a monitoring plan for the barrier's exposed soil cover. The soil cover design uses pea-gravel admix and vegetation to reduce erosion. The monitoring plan proposes to collect data and information about the erosional behavior of the soil under natural rainfall and snowmelt conditions to evaluate the effectiveness of the admix and vegetation in stabilizing the soil surface. 
The monitoring plan consists of two separate data collection efforts: 1) measurement of runoff and sediment yield from a 6-m-wide $\mathrm{x}$ 15-m-long flume installed on the soil surface (controlled-area monitoring), and 2) observation and documentation of the effects of precipitation over the larger remaining surface area (barrier surface monitoring). As part of the surface-monitoring work, rock creep gauges will be installed in the riprap side slope to detect any movement (potential failure) of the rock mass.

The controlled-area monitoring will measure water and sediment runoff from the flume with an automated flow measurement and sediment sampler that operates as rainfall and snowmelt events occur. The automated system consists of a sediment collector to accumulate the water-sediment mixture. Flow meters will measure the inflow and outflow at the collector. Soil moisture probes, thermocouple temperature indicators, and a snow gauge will record snowmelt events. A rain gauge will serve as a backup system to validate rainfall at specific locations.

Time-varying data of overland runoff from rainfall and snowmelt events and corresponding sediment yield will be obtained. The data will be used to analyze erosion caused by precipitation falling on the barrier surface and the corresponding changes in erosivity as the surface ages over the 3-year monitoring period. The results will provide information to evaluate the barrier soil's capacity to resist water erosion.

The method for barrier surface monitoring uses a 3-m x.3-m grid system established on the soil surface to provide a ready field reference system for mapping surface changes. The system was established by setting four corner markers composed of steel rebar enclosed in 3-in. PVC pipe that defines a 36-m x 75-m rectangle centered within the perimeter of the compacted gravel roadway. Interior grid points were located using painted wood surveying stakes numbered to identify grid coordinates.

The rock creep gauges were installed at 11 locations along the rock slope. At each location, the gauges were placed at the slope's midpoint, except for one location near the northeast corner where two gauges were installed at the upper and lower slope elevations. Figure 2.1 shows the grid system, flume location, and layout of the rock creep gauges.

Profile leveling will be used to determine the elevations at each grid point and gauge. The gauge plan positions will be surveyed. All elevations and positions will be checked either seasonally or annually. Specific soil properties, such as density and moisture content, will be measured monthly or seasonally. Changes to the soil surface, such as cracking and rill development, will be measured monthly or seasonally, monitored through photographs, and located with respect to the grid.

Contour maps of the soil surface elevations and post-construction soil properties will be developed. Seasonal or annual changes in the elevations and properties will be documented over the life of the prototype barrier. Maps of changes in vegetation cover and animal burrowing will be developed to relate those changes to erosional trends. The mapping will document the degree of nonuniformity of nearsurface moisture (localized accumulations) together with the other soil properties and changes in those properties over the monitoring period. Their relationship to erosion and infiltration will be investigated in cooperation with 


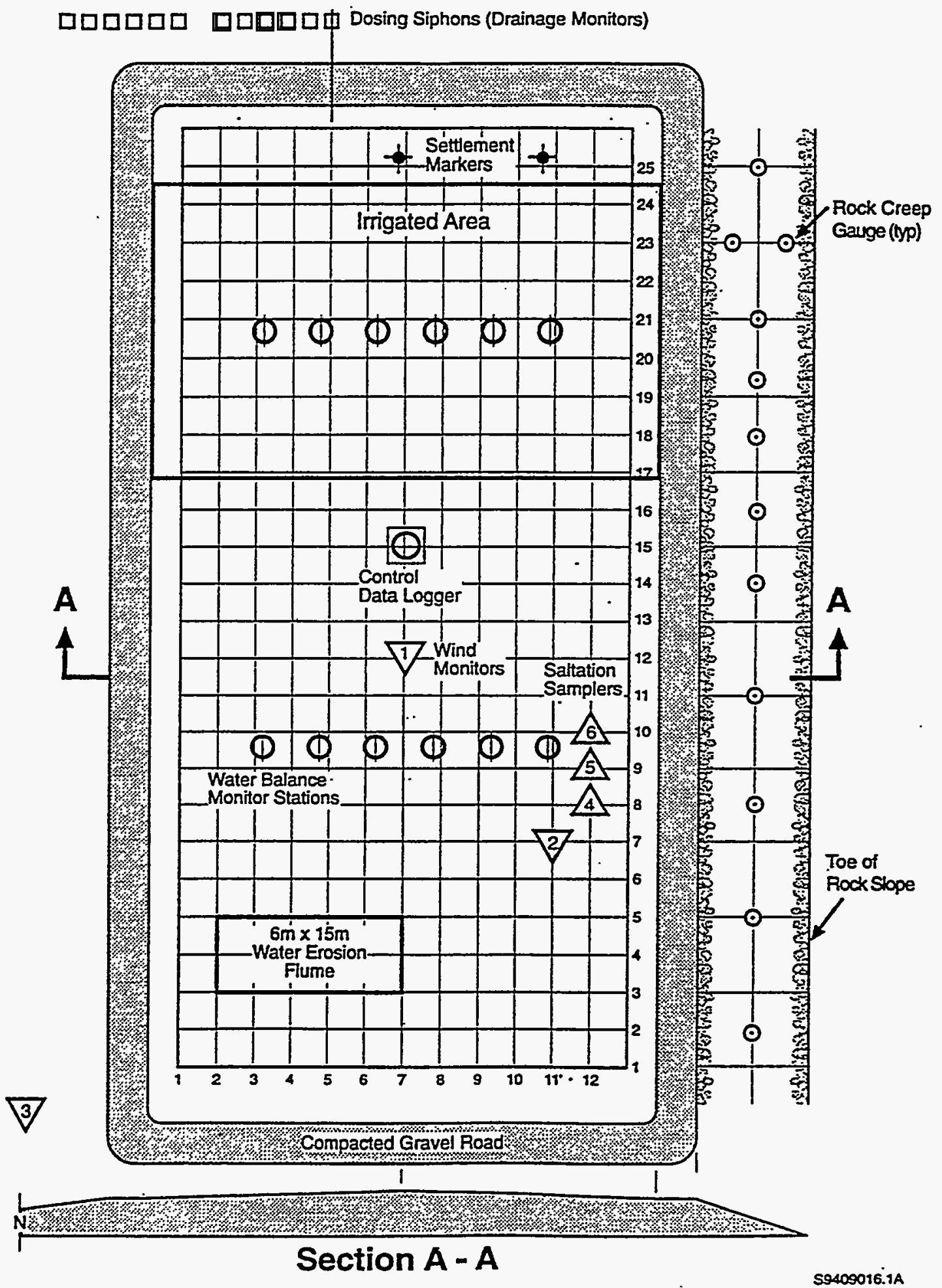

Figure 2.1. Layout of Barrier Surface Grid and Monitoring System 
other tasks. More details on both the controlled-area and barrier surface monitoring plans are presented in the document, The Hanford Prototype Surface Barrier Status Report (Gee et al. 1994).

\subsection{Physical Stability: Extreme Events}

\subsubsection{Assessment of Potentially Disruptive Natural Events - \\ K.L. Petersen (PNL), A.M. Tallman (WHC), and F.M. Corpuz (BHI)}

Those disruptive events determined to have a reasonable probability of occurring during the +1000 -year design life of the Hanford Protective Barrier are being assessed to determine their consequences on the performance of the barrier. Specifically, the assessment covers tornadoes and other high-wind conditions, high-intensity precipitation, the deposition of volcanic ash, earthquakes, and any other possible disruptive events that could affect the Hanford Protective Barrier. The following discussion summarizes the results found to date; full documentation is forthcoming.

Testing and monitoring of the prototype barrier is planned to be conducted for a minimum of 3 years, beginning immediately after the barrier's construction. Data on extremes for wind and precipitation collected during this assessment will provide bounding ranges to be used as part of the testing and monitoring activities.

The wind data collected at the Hanford Site and surrounding locations have been used to develop probabilistic straight-wind and tornado hazard assessments for the Hanford Site. Straight-wind velocities that equal or exceed tornado velocities are at return periods of less than 100,000 years. Tornado winds are expected to be extremely rare on the Hanford Site.

During the 48-year period of record at the Hanford Meteorological Station (1945 through 1993), only 2 days have had more than $25 \mathrm{~mm}$ of precipitation (October 10, 1957 with $40 \mathrm{~mm}$; June 17, 1950 with $27.7 \mathrm{~mm}$ ). The most intense storms in the region are warm season thunderstorms. Storms of 6 hours are more indicative of this type of storm. For prototype barrier testing, it can be noted that according to calculations examined, the 1000 -year storm at the Hanford Site would accumulate $55.9 \mathrm{~mm}$ of precipitation in 6 hours (compared to a maximum record of $42.7 \mathrm{~mm}$ ) and $68.1 \mathrm{~mm}$ of precipitation in 24 hours (compared to a maximum record of $48.5 \mathrm{~mm}$ [October 10-11, 1957]). The 1000-year, 68.1-mm/24-hour amount is $42 \%$ of the entire annual mean precipitation of $160 \mathrm{~mm}$. The $160 \mathrm{~mm}$ is the 30 -year normal precipitation amount.

The maximum annual precipitation received at Hanford through 1993 is $290 \mathrm{~mm}$ (181\% of normal); which occurred in 1950 (the next high is $281 \mathrm{~mm}$ [176\% of normal], which occurred in 1983). Thus, it would seem that for prototype testing, $200 \%$ of normal is probably not adequate on scales of 1000 years. However, for the following reasons, it is believed that $300 \%$ of normal is conservative. Probability calculations indicate the probability that the annual precipitation amount will exceed $310 \mathrm{~mm}$ $\mathrm{yr}^{-1}$ (193\% of normal) is only 1 in 100 years, that it will exceed $410 \mathrm{~mm} \mathrm{yr}^{-1}$ (256\% of normal) is only 1 in 1000 years, and that it will exceed $510 \mathrm{~mm} \mathrm{yr}^{-1}$ (319\% of normal) is only 1 in 10,000 years. The current upper bound for testing the prototype is $300 \%$ of normal (i.e., $480 \mathrm{~mm} \mathrm{yr}^{-1}$ ) (see Section 2.2). 
Although buried evidence of past Columbia River floods provides some stratigraphic evidence for the occurrence of extreme precipitation events during the past 2000 years, there are more paleoclimatic data on long-term precipitation averages. A +75,000-year pollen record from Carp Lake near Goldendale, Washington, provides evidence for estimates that mean annual precipitation in the Columbia River Basin ranged between $50 \%$ to $75 \%$ of modern and $130 \%$ of modern levels (see Section 2.9.1). For the majority of the period recorded in the pollen record (almost 65,000 years out of 75,000 years), the climate in the Columbia Basin was drier than it is now (i.e, averaged less than $160 \mathrm{~mm} \mathrm{yr}^{-1}$ precipitation in the Hanford Site region). Based on the Carp Lake data and other data, it can be concluded there is no evidence that the long-term precipitation average ever reached $300 \%$ of modern levels of precipitation, the average established as the upper bounding annual amount for testing the prototype barrier.

To evaluate the effect of a higher long-term precipitation mean at Hanford (such as $200 \mathrm{~mm}$ of annual precipitation, as implied by the upper bounding long-term average at Carp Lake), data from surrounding weather stations were examined. Major storm systems typically move across the area originating out of the southwest or south. This trend produces a stronger correlation between weather stations aligned along the southwest-northeast direction. To obtain a representative analysis, data from three weather stations were examined: the Yakima station (200 mm mean annual precipitation), at the most southwesterly location; the Lind station (243 mm,) located in the middle; and the Spokane station $(425 \mathrm{~mm})$, located at the northeast end of the transect.
As noted, calculations for the Hanford Site indicate that for any 24-hour period, the probability of precipitation exceeding $68.1 \mathrm{~mm}$ is only. 1 in a 1000 . This is called the "1000-year return period." Hourly precipitation values are not recorded at the Lind station, so annual daily maximum values were selected for comparison from the transect stations. The skewed plot shape for the annual daily maxima distribution of precipitation is usually best described by a Pearson's Type III distribution, an asymptotic distribution constrained by zero on one side and having a long tail on the other. Tables containing percentage point values for Pearson Type III extreme analysis distributions were obtained from the Western Regional Climate Center, Desert Research Institute, Reno, Nevada, and the skewness selected for use were those that most typify weather stations in the region (i.e., about 1.7 for Yakima and Lind and 1.4 for Spokane).

Calculations of the annual daily maxima precipitation with a return period of 1000 years provided the following results: Yakima $(64.5 \mathrm{~mm})$, Lind $(54.9 \mathrm{~mm})$, and Spokane $(53.6 \mathrm{~mm})$. These amounts are surprisingly close to one another, despite the fact that Spokane receives over $209 \%$ of the precipitation of Yakima. It is also interesting that the means of the annual daily maxima precipitation for the three transect sites are also very close in amount (i.e., Yakima, $21.9 \mathrm{~mm}$; Lind, $18.7 \mathrm{~mm}$; and Spokane, $23.6 \mathrm{~mm}$ ). This seems to suggest that Spokane has more days of precipitation instead of bigger daily storms, than, for example, Lind, which is located in the middle of the Columbia Basin, away from any of the surrounding highlands. Based on this analysis, it is believed that the 1000-year, 68.1$\mathrm{mm} / 24$-hour precipitation amount calculated for 
the Hanford Site, if applied to the prototype barrier in 1 day, would represent a conservative stress test even if the mean annual precipitation were higher at the Hanford Site.

The nearest Cascade volcano is more than $100 \mathrm{~km}$ from the Hanford Site. Tephra from the Cascade volcanoes has been found in the sediments in and around the Hanford Site. During the 1980 eruption of Mount St. Helens, about $1 \mathrm{~cm}$ of ash fell on the northern part of the Hanford Site. The hazard from volcanoes is dependent on the probability and type of renewed eruptive activity in the Cascades and the meteorological conditions that control the direction and distance of air transport. The current design load for volcanic ash at the Hanford Site is a ground loading of $117 \mathrm{~kg} \mathrm{~m}^{-2}(24 \mathrm{lb}$ $\left.\mathrm{ft}^{-2}\right)$ for Safety Class 1 structures. The potential impact of such an occurrence on the barrier has not yet been examined in the BDP.

The Columbia River Plateau region, including the Pasco Basin, is an area of low magnitude seismicity compared to the rest of the western United States. The closest regions of historic moderate-to-large earthquake generation are in western Washington and Oregon and western Montana and eastern Idaho. The most significant event relative to the Hanford Site is the 1936 Milton-Freewater, Oregon, earthquake, with a magnitude of 5.75. The largest Modified Mercalli Intensity was felt at Walla Walla, Washington, and was VI. The earthquake was approximately $105 \mathrm{~km}$ from the Hanford Site.

A static slope stability analysis and associated earthquake deformation analyses were performed by Adam Saleh and David Daniels of the University of Texas. They conducted their analyses for the prototype barrier. For a 1000-year design life of the prototype barrier, the average site seismic response spectra with structure damping curves of $5 \%, 10 \%$, and $12 \%$ is a ground acceleration of $0.14 \mathrm{~g}$ for 1000 years and $0.38 \mathrm{~g}$ for 10,000 years. The corresponding, equivalent Richter scale measurement for both is 6.0 at a distance of $15 \mathrm{~km}$.

The significant findings from the static slope stability and seismic deformation analyses are summarized here:

- The minimum static safety factor for the prototype barrier is on the order of 1.5 , occurring along the 2 horizontal to 1 vertical (2:1) basalt side slopes.

- For a 1000-year recurrence interval (63\% probability of exceedance over 1000 years) of seismic loading conditions, the permanent seismic deformations are estimated to be on the order of 0 to $0.08 \mathrm{~cm}$. The displacement plane for the most critical surface is within the wedge of the basalt side slope, starting from the top of the slope and extending vertically downward to the asphalt layer, then extending horizontally, essentially along the asphalt layer to just below the toe of the basalt side slope. The estimated resulting mode, magnitude, and location of deformation is not anticipated to significantly affect the functional performance of the barrier.

- For a 10,000-year recurrence interval (10\% probability of exceedence over 1000 years) of seismic loading conditions, the permanent seismic deformations are estimated to be on the order of 0 to $2.05 \mathrm{~cm}$. The displacement plane 
for the most critical surface is within the wedge of the basalt side slope, starting from the top of the slope and extending vertically downward to the asphalt layer, then extending horizontally, essentially along the asphalt layer to just below the toe of the basalt side slope. The estimated resulting mode, magnitude, and location of deformation is not anticipated to significantly affect the functional performance of the barrier.

\subsection{Water Infiltration Control}

\subsubsection{Field Lysimeter Test Facility - G.W. Gee (PNL)}

\section{Facilities}

The FLTF was renovated during FY 1994. Six lysimeters were excavated and subsequently refilled with materials taken from the prototype barrier (see Section 2.1). The number of individual test treatments was increased from 11 to 17 . The additional treatments are designed to test water balance characteristics of prototype materials under conditions of ambient and elevated precipitation. Figure $2: 2$ shows a schematic view of the renovated lysimeter facility and illustrates each of the 17 treatments.

The FLTF continues to be used for monitoring water balance of covers that incorporate a capillary barrier to prevent drainage until a water storage threshold is reached. Over the past 7 years, the initial 11 treatments, designed to evaluate a wide range of surface barrier conditions for the Hanford Site, have provided key information on surface barrier performance.
This information has led to the design and testing of a large prototype barrier in the 200 East area (see Section 2.1).

\section{Results}

Tests at the FLTF from the initial 11 treatments (Gee et al. 1993b), which cover a wide range of soil, vegetation, and climate conditions, continue to show the advantages of using silt loam soil as a-surface material. Silt loam soil has the largest storage capacity of any material tested and when incorporated in a capillary barrier design (e.g., with silt loam overlying coarse sand), this material can store up to three times the annual average precipitation before drainage occurs.

For vegetated silt-loam surfaces, there has never been any drainage since testing began (over 6 years ago), even under the most extreme climate regime tested (i.e., $480-\mathrm{mm} \mathrm{yr}^{-1}$ precipitation, three times the annual average). However, we have now documented storage limits for Hanford Site silt-loam soil (e.g., Warden silt loam) and have found it to slightly exceed $500 \mathrm{~mm}$ in a 1.5-m-deep profile. Tests with bare silt loam surfaces have shown that under the extreme climate conditions, modest amounts of drainage have occurred over the past 2 years. In early 1993, we observed as much as $\mathbf{3 0 ~ m m}$ of drainage from bare, siltloam lysimeters, while during the past year (1994) we observed less than $10 \mathrm{~mm}$ of drainage from the same lysimeters. For ambient (nonirrigated) treatments, there has not been any drainage from silt loam soils under any treatment (bare surface, vegetated, or vegetated with gravel admixed into the surface). We conclude from this that when vegetation is 

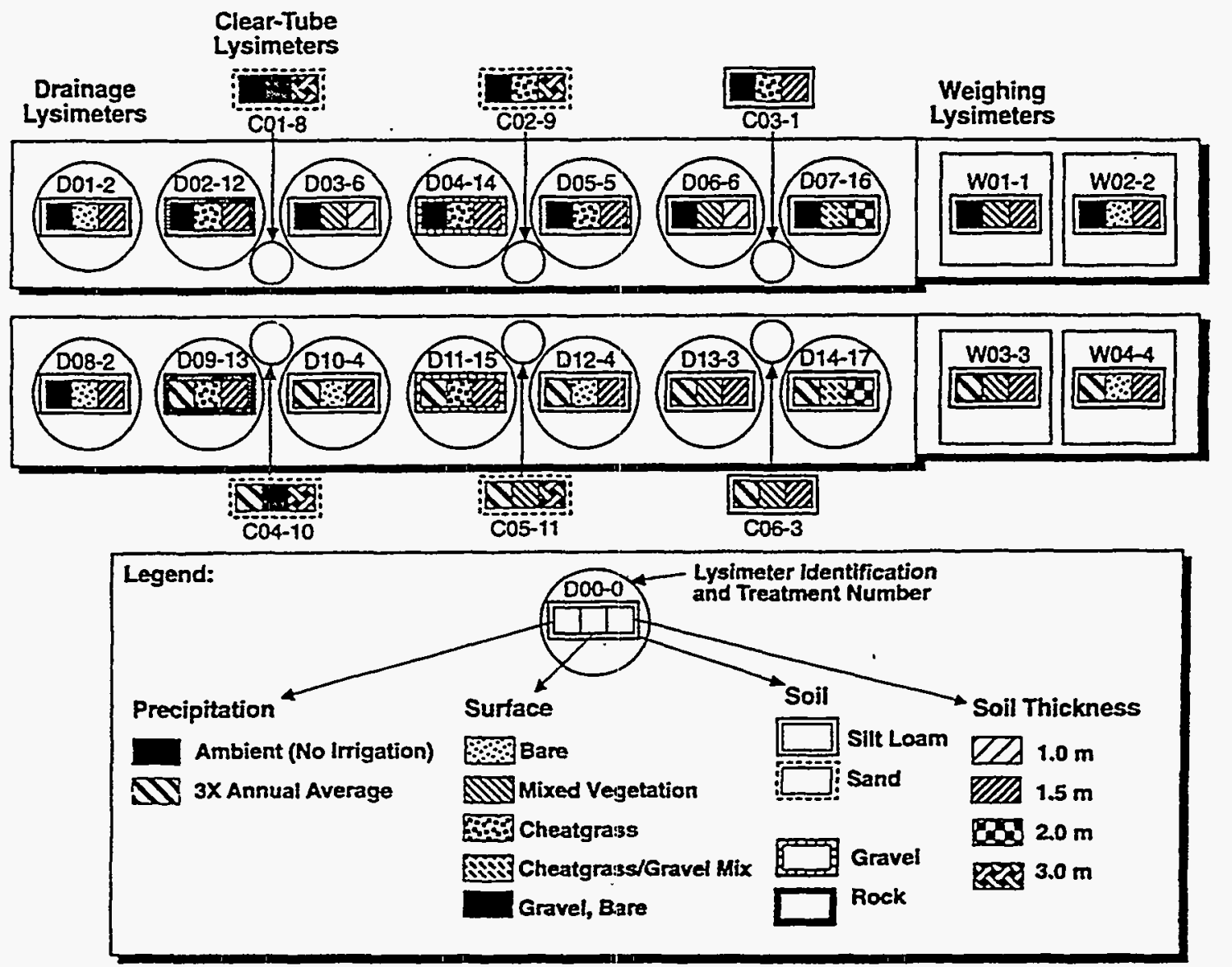

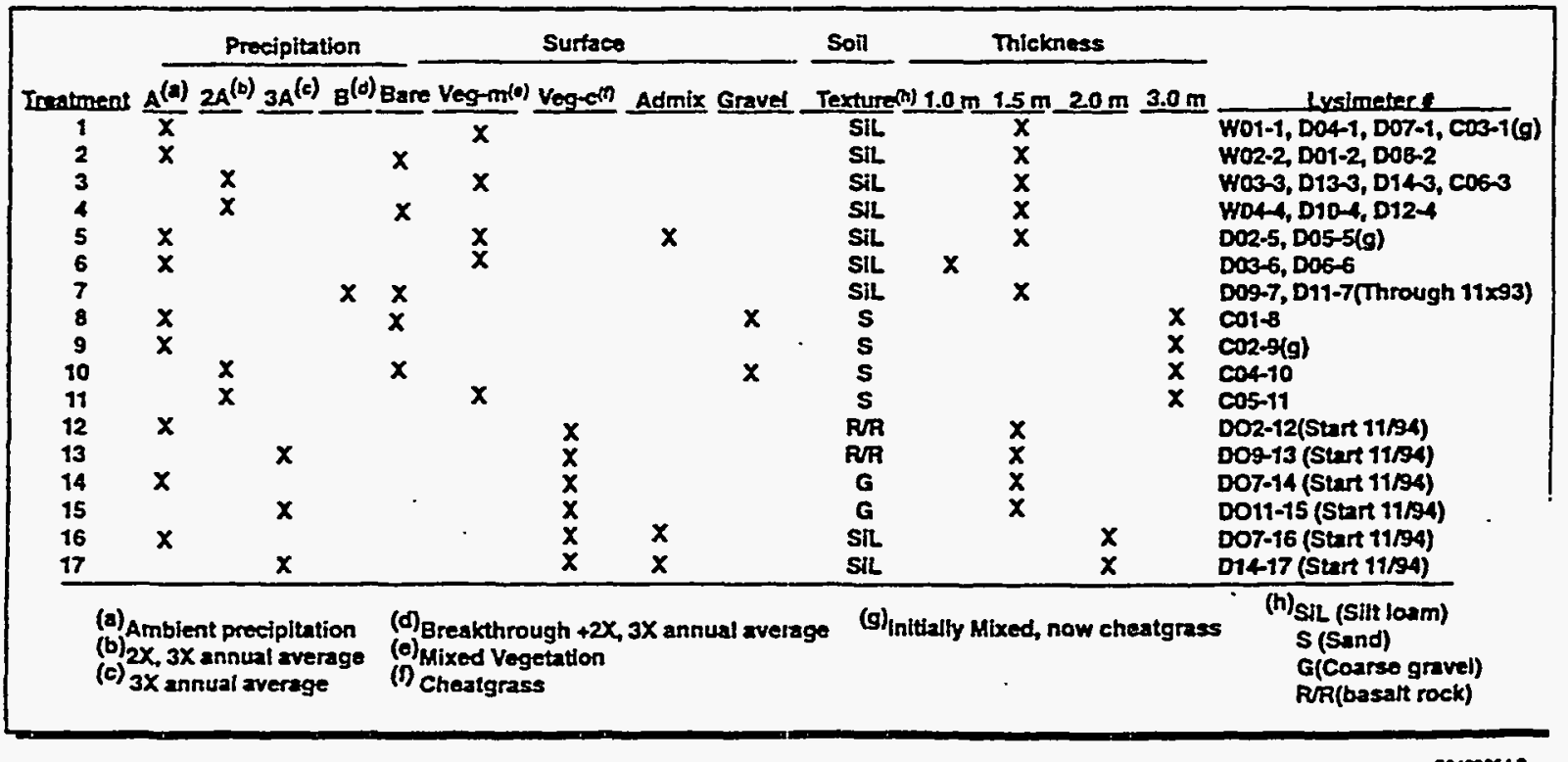

Figure 2.2. Treatment Description of the Field Lysimeter Test Facility, September 1994 (after renovation) 
present, barriers with silt-loam surfaces will not drain, neither under present nor expected future climate conditions at Hanford.

Figure 2.3 shows cumulative drainage from the clear-tube lysimeters at the FLTF. These data clearly illustrate differences in drainage responses with time for three different soil surfaces (gravel, sand, and silt loam).

Gravel surfaces (irrigated and nonirrigated) continue to drain a large percentage of the applied water. More than two-thirds $(1417 \mathrm{~mm}$ of $2115 \mathrm{~mm}$ ) of all applied water has drained from the irrigated, gravel-covered lysimeter since 1990. The ambient, gravel-covered lysimeter has drained nearly half $(356 \mathrm{~mm}$ of $811 \mathrm{~mm}$ ) the incident precipitation over the same time period.

Vegetated sand surfaces have also drained significant quantities of water. Irrigated, vegetated sand had $250 \mathrm{~mm}$ of drainage since 1990 , while nonirrigated, vegetated sand had $53 \mathrm{~mm}$ of drainage for the same time period. The amount of drainage is dependent upon seasonal distribution of precipitation as well as vegetation type (e.g., grass-covered surfaces drained more readily than shrub-covered surfaces). We conclude from these tests that gravel or sandcovered waste sites at Hanford are highly susceptible to drainage under both present and

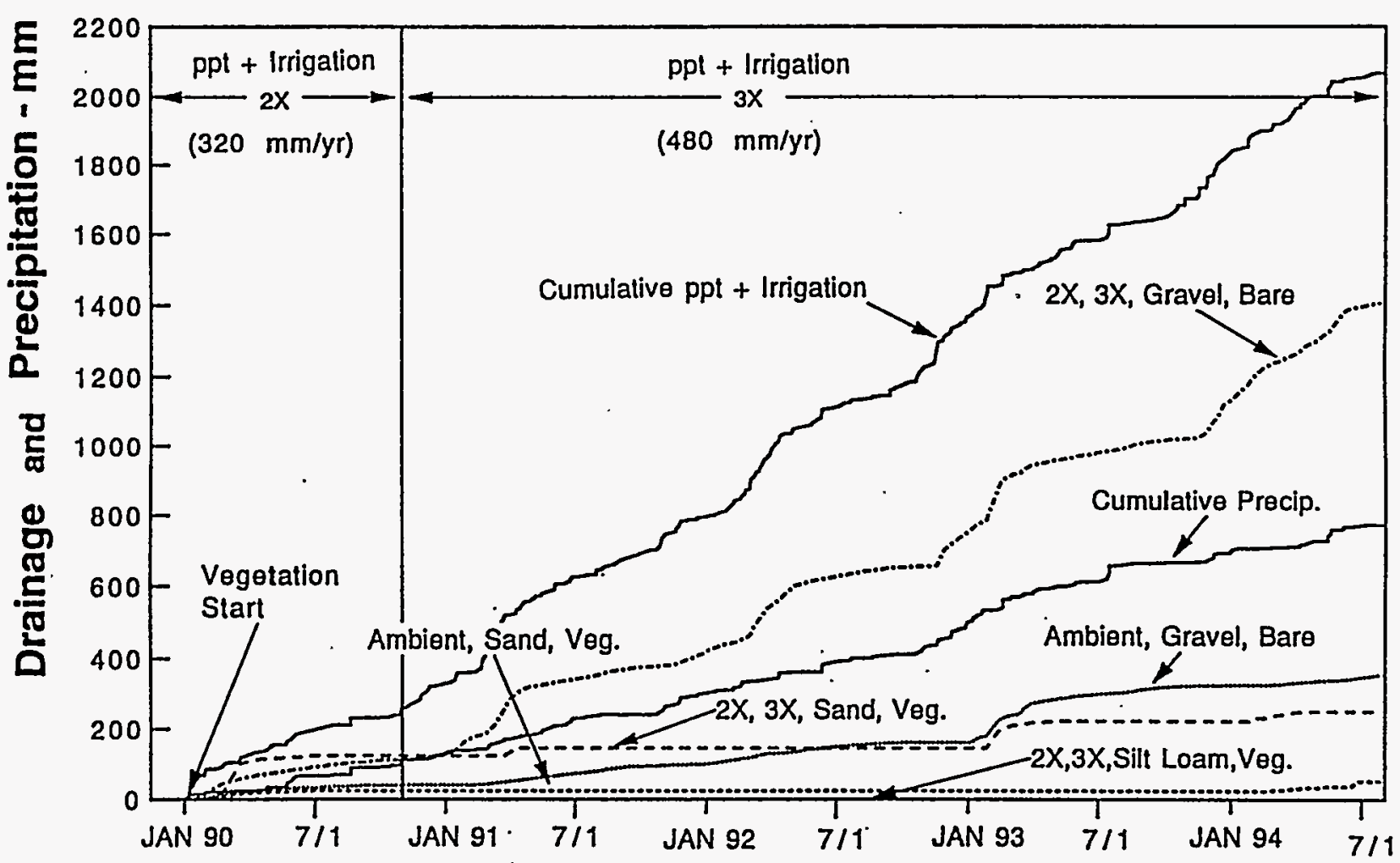

Figure 2.3. Drainage from Small Tube Lysimeters Through July 1994 
expected future-climate conditions. The observations support barrier designs at Hanford that incorporate fine soils (e.g., silt loams) into the surface. The observations also suggest that coarse side-slope materials incorporated into barrier designs will be susceptible to drainage. For above-grade barriers, which require coarse side-slope materials, drainage from the sideslopes will need to be addressed to protect underlying wastes from surface recharge.

\section{Future Work}

Activities for the next 3 years at the FLTF will include monitoring all lysimeters for water balance parameters under irrigated and ambient conditions. In early November 1994, all renovated lysimeters were seeded with cheatgrass. Testing of the renovated lysimeters began at that time and data subsequently collected to aid in the design and testing of prototype materials. All current treatments will be maintained, and the facility will continue to be used to obtain key water balance data needed for Hanford surface-barrier development and predictive modeling.

Neutron probe measurements and irrigation applications will be made on a biweekly basis. Irrigation water will be applied in amounts such that monthly rates mimic three times the longterm monthly average. Thus, late fall, winter, and early spring applications rates will dominate, because these periods typically have the most precipitation at the Hanford Site. Snow applications will be made in winter months and will correspond as closely as possible to times when snow will be applied to the prototype barrier during its testing phase. It has proven difficult to apply irrigation water in the winter (late November through early March) because of freezing conditions, so snow applications will be preferred.

Weekly, seasonal, and annual water storage data will be used to report evapotranspiration (computed as the difference between water storage and the sum of precipitation and drainage) for all vegetated treatments. Differences in evapotranspiration will be related to climate and plant variables and documented for all applicable treatments. Data from all weighing lysimeters will continue to be automated and stored in the PNL data base. The large (10-MT capacity) platform scales used as part of the weighing lysimeters will continue to be calibrated annually. Tensions (soil water suctions) will be measured in the bottoms of all renovated lysimeters. Equipment will be modified to allow continuous measurement of the suctions in the wettest lysimeters.

Drainage from the prototype side-slope materials is expected to be significant, so tipping bucket raingages have been installed to monitor the high flow rates expected in early spring. The surfaces of the lysimeters will be kept free of summer annuals (tumble weed, tumble mustard, etc.) and bare soil surfaces will be kept free of vegetation throughout the testing.

The FLTF data base will continue to be checked and verified on a weekly basis. Past and present data will be archived in a retrievable data base that can be made readily available for use in model verification activities. The FLTF data base will continue to be used by PNL and others to test performance of simplified and detailed water balance models for the Hanford Site. In FY 1995, data quality objectives will be established for the key 
parameters needed for model verification and the data checked against those objectives.

\subsubsection{Asphalt Technology H.D. Freeman (PNL)}

The asphalt layer within the Hanford Protective Barrier is an important component of the overall design. This layer provides a RCRA-equivalent backup to the overlying earthen layers in the unlikely event these layers cannot reduce the infiltration rate to less than $0.05 \mathrm{~cm} \mathrm{yr}^{-1}$. Only a limited amount of information exists regarding the use of asphalt for a moisture infiltration barrier over the long times required by the Hanford Protective Barrier. Therefore, a number of activities are under way to obtain data on the performance of asphalt as a moisture barrier in a buried environment over a 1000-year period. These activities include 1) determining RCRA equivalency, 2) measuring physical properties, 3 ) measuring aging characteristics, and 4) determining relationships to ancient asphalt analogs. During FY 1994, progress was made on all of these activities. Studies were conducted both in the laboratory and on the prototype barrier constructed in the 200 East Area on the Hanford Site.

Hydraulic conductivity measurements of the hot-mixed asphalt concrete layer of the prototype barrier were made using both laboratory permeameters with core samples and in-place field falling head permeameters (FHP). These techniques provided complementary data that showed the asphalt concrete layer exceeded the RCRA hydraulic conductivity performance criteria of $1 \times 10^{-7} \mathrm{~cm} \mathrm{~s}^{-1}$.
Field hydraulic conductivity measurements were made using a new in-place FHP. The permeameter shown in Figure 2.4 measures an area of $\sim 0.05 \mathrm{~m}^{2}$ and is constructed of a stainless steel confining ring with an acrylic top and stand tube. The permeameter is sealed into a groove cut 5 to $10 \mathrm{~cm}$ deep and sealed with pure bentonite or bentonite grout. The water head used in the measurement is controlled by the amount of water placed in the stand tube. The water head used in these measurements was approximately $2 \mathrm{~m}$, a volume that accelerated the test by a factor of 3 to 6 over a normal sealed double ring infiltrometer (SDRI) test. Another advantage over SDRI techniques is that these permeameters can be easily transported and set up by one person.

Results of the FHP measurements made at the north end of the prototype barrier are shown in Table 2.1. These data show that measurements at all locations except location 2 are below the RCRA criteria of $1 \times 10^{-7} \mathrm{~cm} \mathrm{~s}^{-1}$. The measurement at location 2 is much higher because it was made directly on a surface seam. Because the confining rings did not completely penetrate through the top lift of asphalt, a path for water movement under the confining ring was present, resulting in higher hydraulic conductivity. This measurement is most likely invalid because it does not measure the hydraulic conductivity through both layers of hot-mixed asphalt concrete, highlighting the need to ensure that the test grooves and confining ring of the permeameter must be deep enough to completely penetrate the top layer of asphalt concrete. 


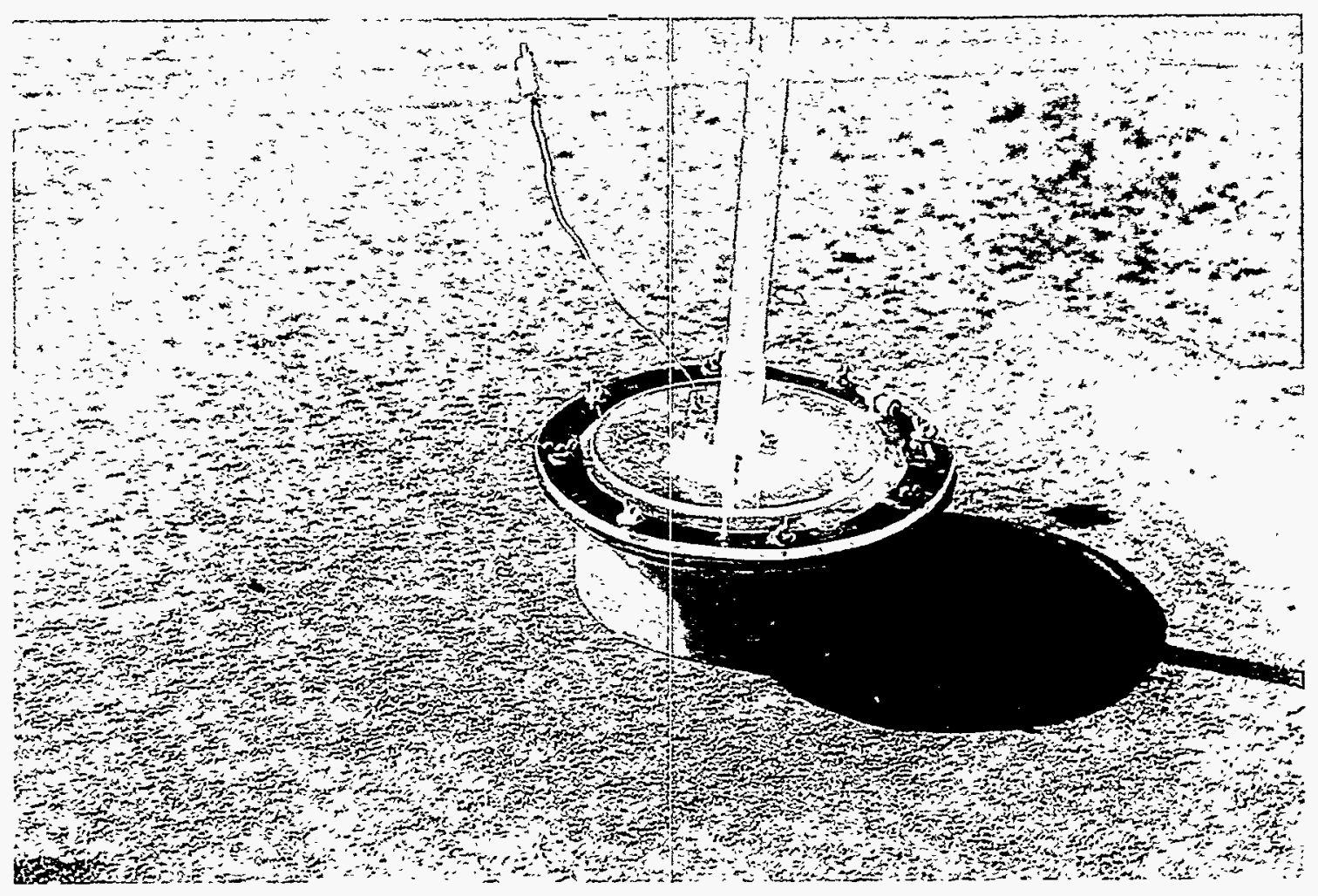

Figure 2.4. Field Falling Head Permeameter Used for Prototype Measurements

Table 2.1. Hydraulic Conductivity of Hot-Mixed Asphalt Concrete Layer of Prototype Barrier, $\mathrm{cm} \mathrm{s}^{-1}$

\begin{tabular}{clllll}
\hline Location & $27-\mathrm{Apr}$ & $28-\mathrm{Apr}$ & $29-\mathrm{Apr}$ & $30-\mathrm{Apr}$ & $1-\mathrm{May}$ \\
\hline 1 & --- & --- & $3.09 \times 10^{-8}$ & $3.88 \times 10^{-8}$ & $1.91 \times 10^{-9}$ \\
2 & -- & --- & $3.92 \times 10^{-7}$ & $2.16 \times 10^{-7}$ & $1.08 \times 10^{-7}$ \\
3 & $1.05 \times 10^{-7}$ & $3.06 \times 10^{-8}$ & $2.09 \times 10^{-8}$ & $5.66 \times 10^{-9}$ & $1.47 \times 10^{-8}$ \\
4 & --- & $9.27 \times 10^{-8}$ & $9.69 \times 10^{-8}$ & --- & $4.33 \times 10^{-8}$ \\
5 & --- & $5.44 \times 10^{-8}$ & $2.80 \times 10^{-8}$ & $1.43 \times 10^{-8}$ & $1.51 \times 10^{-8}$ \\
\hline
\end{tabular}




\section{Laboratory Hydraulic Conductivity Measurements on Prototype Core Samples}

Twelve core samples were taken at six locations (two per location) at the north end of the prototype barrier for use in field hydraulic conductivity measurements. Five of these cores were selected for testing while the remainder were reserved for later tests. Measurements were made using standard laboratory falling head measurement techniques using 2.5-m water of hydraulic gradient. Daily measurements were made by noting the height of water in a 5-ml pipette attached to the top of each test setup. Tests were carried out for over 3 weeks and hydraulic conductivity was calculated based on the change in water column height over the 3-week period (Table 2.2). Overall, the cores averaged $4.69 \times 10^{-10} \mathrm{~cm} \mathrm{~s}^{-1}$, which is much lower than that measured by field techniques. This was expected because the field technique has several conservative assumptions that result in calculating a higherthan-actual hydraulic conductivity.
Table 2.2. Summary of Hydraulic Conductivity Data for Prototype Hot-Mixed Asphalt Concrete Cores

\begin{tabular}{ccc}
\hline Sample & $\begin{array}{c}\text { Thickness, } \\
\mathrm{cm}\end{array}$ & $\begin{array}{c}\text { Hydraulic } \\
\text { Conductivity, } \\
\mathrm{cm} \mathrm{s}^{-1}\end{array}$ \\
\hline $1 \mathrm{~A}$ & 15.3 & $1.32 \times 10^{-9}$ \\
$2 \mathrm{~A}$ & 14.8 & $3.45 \times 10^{-10}$ \\
$3 \mathrm{~A}$ & 16.7 & $2.42 \times 10^{-10}$ \\
4A & 17.1 & $1.24 \times 10^{-10}$ \\
$5 \mathrm{~A}$ & 14.1 & $3.16 \times 10^{-10}$ \\
\hline Average & 15.6 & $4.69 \times 10^{-10}$ \\
\hline
\end{tabular}

\section{Laboratory Hydraulic Conductivity Measurements on Fluid-Applied Asphalt Membrane Samples}

Hydraulic conductivity measurements on samples taken from the prototype barrier dur-ing installation of the fluid-applied asphalt were made using the same techniques as described for the prototype core samples. Table 2.3 shows results from the measurements.

Table 2.3. Hydraulic Conductivity of Polymer-Modified Asphalt Membrane Samples from Prototype Barrier

\begin{tabular}{cccl}
\hline Sample & Thickness, cm & $\begin{array}{c}\text { Hydraulic } \\
\text { Conductivity, } \mathrm{cm} \mathrm{s}^{-1}\end{array}$ & \multicolumn{1}{c}{ Description } \\
\hline 1 & 0.160 & $1.36 \times 10^{-11}$ & $\begin{array}{l}\text { Fluid-applied asphalt applied to geo- } \\
\text { fabric (test strip) }\end{array}$ \\
2 & 0.265 & $1.18 \times 10^{-11}$ & $\begin{array}{l}\text { Sample taken on } 5 / 15 / 94 \\
3\end{array}$ \\
0.275 & $2.49 \times 10^{-11}$ & Sample taken from strip Z \\
4 & 0.500 & $2.51 \times 10^{-11}$ & Sample taken from strip AA \\
\hline
\end{tabular}


Measurements made on the fluid-applied asphalt membrane (polymer-modified asphalt) show an extremely low permeability of less than $1 \times 10^{-11} \mathrm{~cm} \mathrm{~s}^{-1}$. This confirms that the combination of hot-mixed asphalt concrete and fluid-applied asphalt will likely exceed the RCRA criteria by several orders of magnitude and also exceed the goal for the protective barrier of $1.6 \times 10^{-9} \mathrm{~cm} \mathrm{~s}^{-1}$ by nearly 2 orders of magnitude. The use of the fluid-applied asphalt as a surface coating on the hot-mixed asphalt concrete should alleviate any concerns that surface seams in the hot-mixed asphalt concrete might compromise the overall performance of the asphalt barrier.

\section{Asphalt Test Pad Monitoring}

Tests using SDRI techniques are currently under way on the asphalt test pad north of the prototype barrier to determine the hydraulic conductivity of a seamed and unseamed area of the test pad. The SDRI tests will give data on hydraulic conductivity of larger areas of hotmixed asphalt concrete without the bias of lateral flow of water from the test area. Tests were originated in September 1994 and should be completed by November 1994. Two FHP tests will be run near the SDRI tests to permit direct comparison of the techniques.

\section{Accelerated Aging Studies}

Numerous activities were conducted in FY 1994 to prepare for accelerated aging studies to be conducted in FY 1995. Most of these activities were conducted to obtain baseline data on asphalt binder properties for comparison to aged materials. In many cases these data were compared to data obtained from studies conducted as part of the Strategic Highway Research Program (SHRP). Most of these tests are standard highway quality control tests for asphalt binders that measure the viscoelastic properties of the pure asphalt binder. The physical properties of several asphalt/aggregate mixes were also tested using Marshall stability and indirect tensile tests.

The accelerated aging protocol was tested in small $(200-\mathrm{ml})$ pressure cells by aging samples of several asphalt binders for. 20 hours at $100^{\circ} \mathrm{C}$. Residues from these tests were analyzed using high-pressure liquid chromatography (HPLC) techniques and compared to Chumash artifacts. Results show that significantly longer exposure times are needed to obtain similar increases in molecular weight of the asphalt binder as that observed in the 1000to 2000-year-old artifacts. Larger aging cells are currently being fabricated to allow greater quantities of asphalt to be aged in each test. Residues from these aging studies will be analyzed with a new technique, dynamic rheometery, to determine viscioelastic properties of the aged binders at expected barrier temperatures.

\subsubsection{Asphalt Analog Studies - R.A. Romine, A.H. Zacher, and H.D. Freeman (PNL)}

The primary objective of this task is to use archaeological samples of asphalt to establish the long-term durability of modern, manufactured asphalt materials used in constructing the Hanford Protective Barrier. People have used natural asphalt, or bitumen, for a documented 5000 years, and prehistoric peoples may have used it for a considerably longer period. Most natural asphalt sources share common features that made them attractive for use by early cultures: a high degree of water repellency, lack of volatility, pronounced adhesiveness, impermeability, and longevity. These are the 
same properties that stimulated interest in incorporating asphalt into nuclear waste containment systems.

Archaeological samples of asphalts that were buried are analogous with the proposed impermeable asphalt component of the Hanford Protective Barrier. Both were heated and intentionally formed within a short time before being sealed from light and most oxygen. The archaeological specimens remained buried until their discovery, often many centuries later. Archaeological samples of asphalts are therefore expected to provide valuable information, not available from any other source, about the long-term aging behavior of buried asphalt and its effect on barrier performance.

The strategy to assess the long-term performance of asphalt was to acquire a dated series of archaeological asphalt, ranging in age from 500 to 4000 years, along with naturally occurring asphalt from the same vicinity. The asphalt artifacts and natural seep material were analyzed chemically to develop a better understanding of chemical reactions of asphalt during extremely long-term aging in a reduced oxygen environment and in the absence of UV radiation. The result will be a set of data that will be used to "calibrate" an accelerated aging process by which experimental samples (modern asphaltic materials used in constructing the Hanford Protective Barrier) will be conditioned to simulate long-term aging. The data gathered in these studies will be useful for evaluating the long-term stability and effectiveness of commercial asphalts proposed for use as barriers at Hanford.

The technical approach used for identifying and characterizing archaeological samples of asphalt follows.
- Select a series of asphalt samples from archaeological sites in proximity to natural asphalt seeps.

- Obtain samples of unaltered or asphalt analog samples from nearby natural seeps.

- Determine the length of burial for the selected asphalt artifacts.

- Establish that asphalt artifacts and natural asphalt are derived from the same petroleum deposit (sourcing).

- Chemically analyze archaeological asphalt to determine the effects of longterm aging in a buried environment.

The following sections detail the results and conclusions obtained from characterizing a series of archaeological artifacts identified from the Santa Barbara, California, region, an area historically occupied by the Chumash Indians.

\section{Radiocarbon Dating}

Radiocarbon dating was used to analyze a series of artifacts. These artifacts were reported in the archaeological literature to range in age from $400 \mathrm{BP}$ to $5000 \mathrm{BP}$. With all of the radiocarbon-dated artifacts, asphalt either adhered to the artifact or an asphalt artifact was found in close association with the artifact in the archaeological excavations. These data directly link the asphalt artifacts to the time when they were interned in a burial site. Table 2.4 details the radiocarbon-dating results. The reported dates have been adjusted by carbon-13. 
Table 2.4. Radiocarbon Dates of Chumash Artifacts

\begin{tabular}{|c|c|}
\hline Sample & $\begin{array}{c}\text { Carbon-13 } \\
\text { Adjusted Age (BP) }\end{array}$ \\
\hline HCRL-1 & $1810+/-60$ \\
\hline HCRL-2 & $1880+/-70$ \\
\hline HCRL-3 & $400+/-50$ \\
\hline HCRL-4 & $2030+/-70$ \\
\hline HCRL-9 & $1160+/-50$ \\
\hline HCRL-10 & $1510+/-60$ \\
\hline HCRL-10a & $1400+/-60$ \\
\hline HCRL-11 & $1970+/-70$ \\
\hline HCRL-14 & $4160+/-100$ \\
\hline
\end{tabular}

The results of these analyses show that we were able to obtain asphalt artifacts that had been interned for a relatively short period (400 years) and several samples that had been interned from two to four times the design criteria identified for the asphaltic components of the Hanford Protective Barrier. The radiocarbon-dating data allows us to evaluate subsequent chemical analyses [infrared spectroscopy (IR) and HPLC] data and base the results of these analyses on a timeline associated with the duration of internment of the artifacts. This approach effectively provides a timeline stretching back more than 4000 years and forward to the present.

\section{Elemental Analysis}

The concentrations of nickel and vanadium were determined for seven asphalt artifacts and five asphalt analog samples. Our primary concern was to effectively establish that the asphalt analog samples were the starting materials used in the manufacture of the asphalt artifacts.

Table 2.5 outlines the results of the nickel and vanadium analyses.

The most significant feature of these data is the ratio of nickel to vanadium. This ratio has been used extensively to identify the source of crude oils and petroleum products. The ratio of $\mathrm{Ni} / \mathrm{V}$ remains constant through processing and is independent of the concentration of insoluble materials (a feature common to natural asphalts and subsequently the artifacts) and the duration of internment at an archaeological site. The $\mathrm{Ni} / \mathrm{V}$ ratio for the asphalt artifacts is very similar to that for the asphalt analog samples-analog-8, analog-9, and analog-26. These three analog samples are from active seeps in

Table 2.5. Elemental Analysis of Asphalt Analog and Artifact Samples

\begin{tabular}{lccc}
\hline Sample & $\begin{array}{c}\text { Nickel } \\
\text { (ppm) }\end{array}$ & $\begin{array}{c}\text { Vanadium } \\
\text { (ppm) }\end{array}$ & Ni/V \\
\hline HCRL-1 & 110 & 370 & 0.29 \\
HCRL-2 & 97 & 300 & 0.32 \\
HCRL-3 & 100 & 360 & 0.28 \\
HCRL-4 & 74 & 230 & 0.32 \\
HCRL-6 & 86 & 210 & 0.41 \\
HCRL-9 & 110 & 330 & 0.33 \\
HCRL-1 & 42 & 110 & 0.38 \\
Analog-5 & 2.7 & 5.2 & 0.52 \\
Analog-8 & 110 & 270 & 0.40 \\
Analog-9 & 110 & 350 & 0.31 \\
Analog-16 & 8.2 & 13 & 0.63 \\
Analog-26 & 85 & 230 & 0.37 \\
\hline
\end{tabular}


the area. The consistency of this material is very similar to a hard, roofing grade asphalt material. Ethnographic information suggests that this is the type of material most commonly used for manufacturing various asphaltic artifacts. Samples analog-5 and analog-16 are much more like crude oil in consistency and have a much higher $\mathrm{Ni} / \mathrm{V}$ ratio. These results verify that in future work to develop an accelerated aging procedure, seep materials found on the cliffs near Santa Barbara should be used, not the liquid materials that float up onto the beach.

\section{Qualitative IR Analysis}

It was necessary to determine whether the Chumash used pine pitch to modify the asphalt.
Functionalities present in pine pitch would interfere with the quantitative analysis of the asphalt artifacts. An IR spectra was obtained for a sample of pine pitch collected at Coal Oil Point, one of the sites where asphalt analog samples were collected in the field. This spectra was compared to several of the artifact spectra. Figure 2.5 shows the spectra of an artifact overlaid with that of the pine pitch.

There is a strong absorbance at $1275 \mathrm{~cm}^{-1}$ in the pine pitch sample that is not present in the artifact. None of the artifacts analyzed showed any evidence of modification with pine pitch. An asphalt analog sample, Coal Oil Point (fresh float), was modified in the laboratory with one percent (wt/wt) pine pitch. The reference absorbance for the pine pitch, $1275 \mathrm{~cm}^{-1}$; was clearly detectable at this low level.

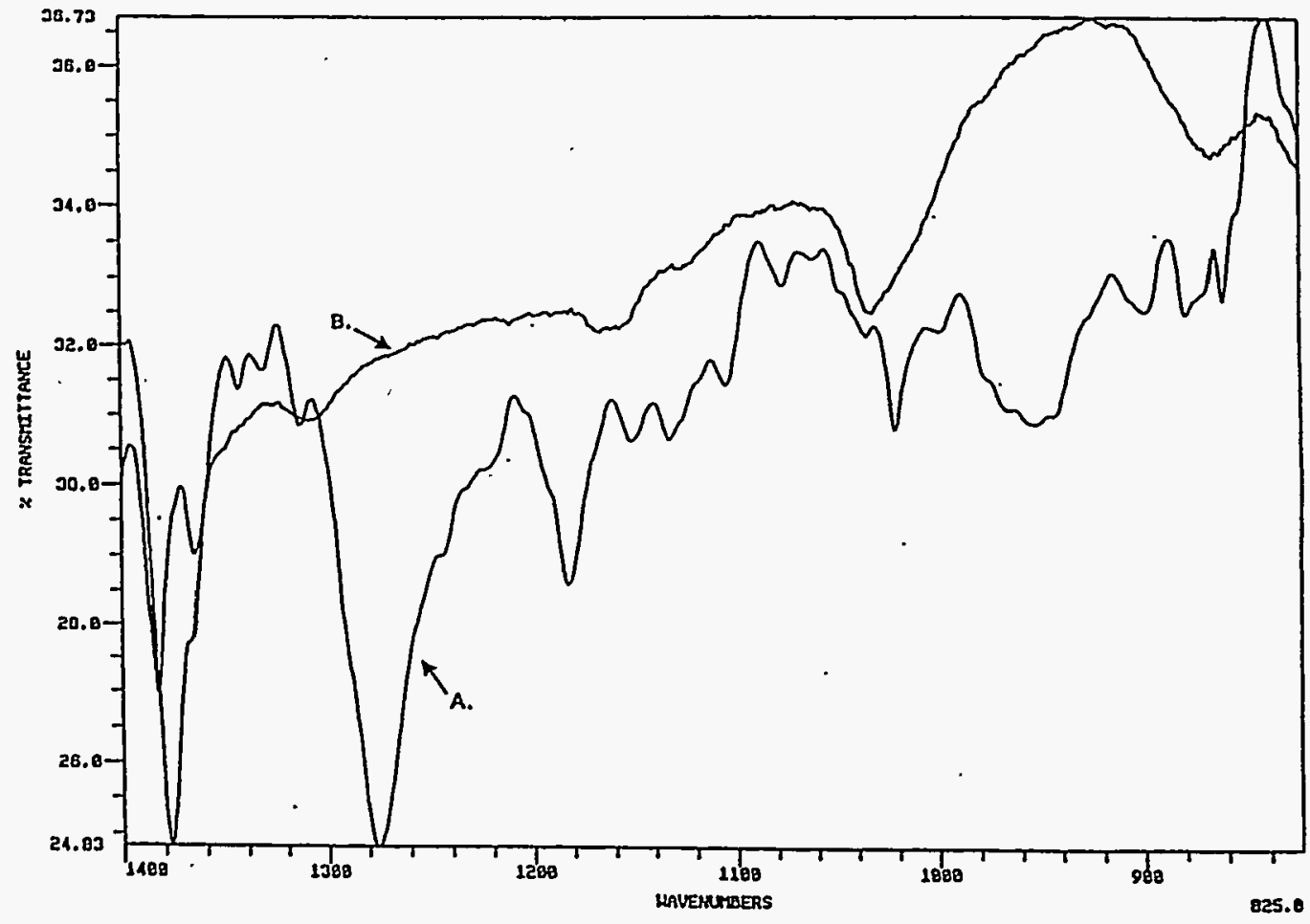

Figure 2.5. Qualitative IR Spectra of A) Monterey Pine Pitch and B) Asphalt Artifact HCRL-10 


\section{Quantitative IR Analysis}

Quantitative IR functional group analyses were performed on four asphalts from the SHRP Materials Reference Library (SHRP-MRL), asphalt artifacts, and asphalt analog samples. Asphalts from the SHRPMRL were analyzed to provide reference data for the analysis. Functional group analysis was performed on the asphalt samples to specifically characterize the following products of oxidative aging: phenolic, pyrrolic, sulfoxide, carbonyl, ketone, carboxylic acid, and anhydride functionalities. This analysis is lengthy and difficult to perform. The procedure is based on performing a number of different derivitization reactions that selectively consume a specific functionality in the asphalt. The IR spectra are taken before and after the derivitization reactions; the difference in the spectra provides a quantitative measurement of the concentration of the functionality. The derivitization reactions have been performed and IR spectra have been obtained for all of the SHRP-MRL asphalts, asphalt artifact, and asphalt analog samples.

The remaining effort in this task is primarily focused on analyzing the data generated in the analysis. Many model compounds must be analyzed to accurately calibrate the IR bench. The model compounds have been analyzed and the response factors calculated. The results of these data will be analyzed relative to the ages established by radiocarbon dating to establish changes in chemistry over extremely long periods of time.

\section{HPLC-SEC Analysis}

As asphalt ages, poly-condensation reactions cause increases in average molecular size.
Poly-condensation reactions are largely the result of oxidative coupling reactions, which combine smaller molecular weight materials into larger molecules. This increase in molecular size is one of the primary factors in age hardening (or brittling) of asphaltic materials. This behavior is especially important in the context of long-term durability, because the aged materials would be more susceptible to cracking.

Increases in the molecular size of the materials result in changes in the chromatogram produced using HPLC-size exclusion chromatography (SEC). These changes can be easily quantified. Large molecular size (LMS) materials are the first to elute in SEC separations, so as an asphalt ages it is predicted that the area percent of the LMS region of a chromatogram should increase. HPLC-SEC separation was developed and performed on four SHRP-MRL asphalts, asphalt artifacts, and asphalt analog samples. A UV-Vis detector was used in the analysis. Three different wavelengths in the UV (230 nm, $254 \mathrm{~nm}$ and $280 \mathrm{~nm}$ ) were evaluated. The chromatograms were bi-modal with various shoulders present. Figure 2.6 shows a typical HPLC-SEC chromatogram for an asphalt artifact.

Jandel Scientific-Peak Fit software was used to quantify the HPLC-SEC chromatograms generated from the analysis of the asphalt samples. This software has excellent subroutines for the deconvolution of complex chromatograms (see Figure 2.5). Peaks in the chromatograms exhibited good symmetry, so we decided to keep the peak fit model as simple as possible. Therefore, an area Gaussian model was used in the analysis. 

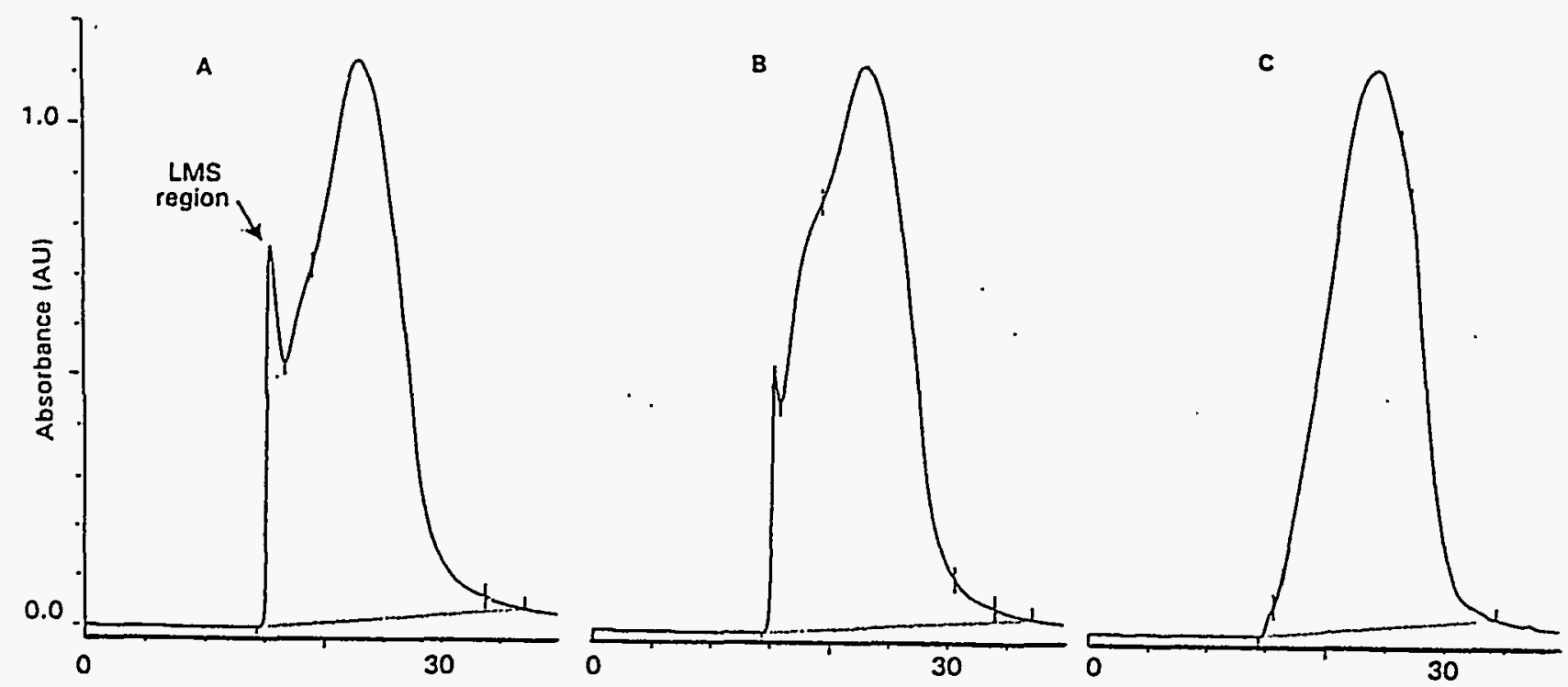

Time (min)

Figure 2.6. HPLC-SEC Plots Illustrating the Change in the LMS Region for A) Artifact Sample HCRL-14 (4160 BP +/- 100 Years), B) Artifact Sample HCRL-10 (1510 BP +/- 60 Years), and C) Analog Sample Analog-9

For the HPLC-SEC analysis of the asphalt artifacts and asphalt analogs, the area percent of the first peak (which represents the LMS) was quantified and plotted versus the duration of internment (based on radiocarbon dating) of the artifact. This analysis provides the first direct representation of how the chemical composition of buried asphalt artifacts change as a function of time (from present time to 4160 years BP). Figure 2.7 details the results of this analysis. This result is of great importance, because it provides the first insights into a physical properties model for the long-term aging of asphalt and how the asphalt will function as a part of the Hanford Protective Barrier. Based on this analysis, a clear relationship between the increase in the LMS as a function of duration of internment of the asphalt artifacts was established.

This data, along with the data from the quantitative IR analyses, will be used to "calibrate" the accelerated aging procedure being developed as part of the Asphalt Technology Task. 


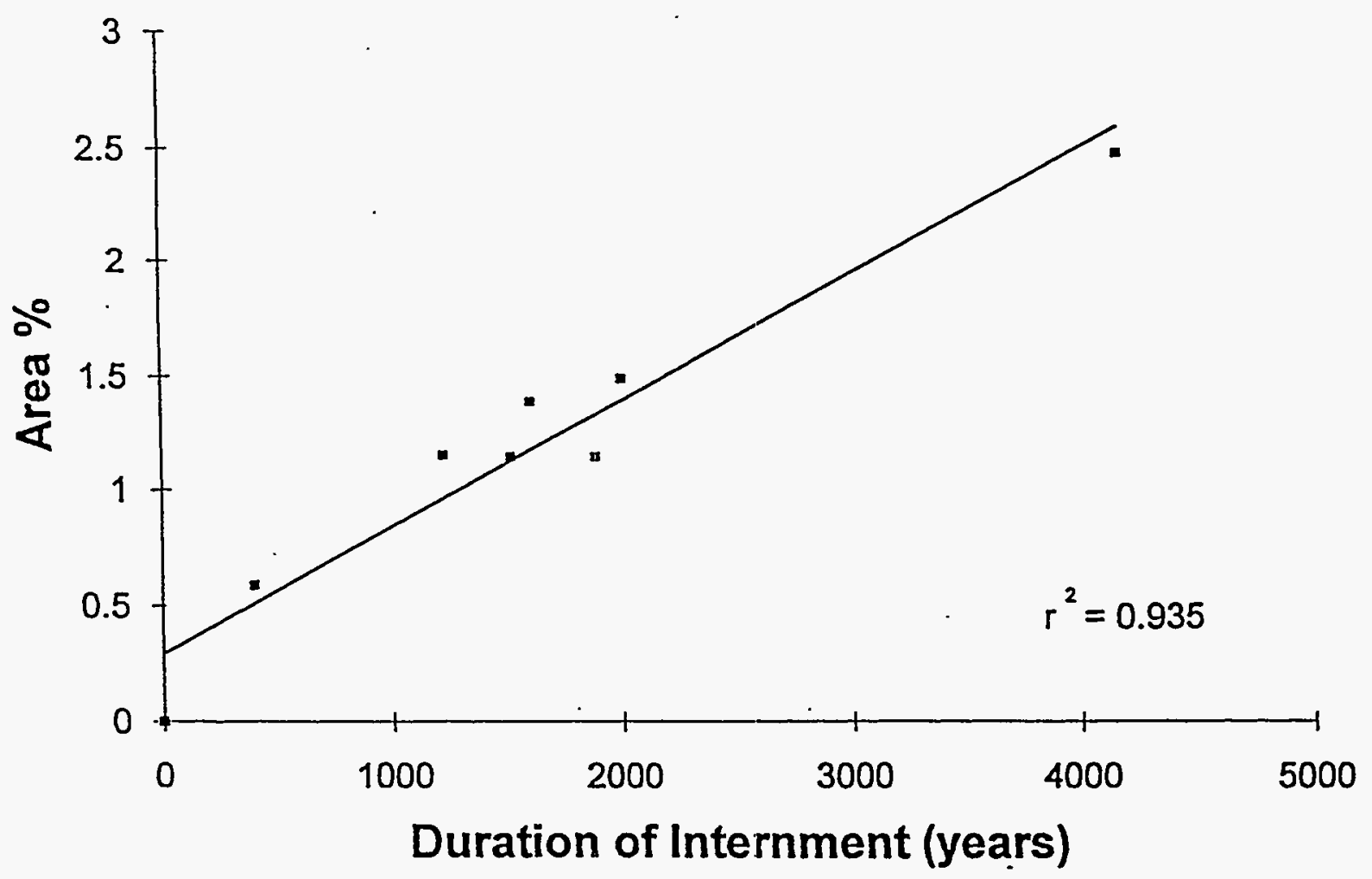

Figure 2.7. Plot of Area Percent of the LMS for Asphalt Artifacts as a Function of Age of Internment, as Determined by Radiocarbon Dating

\section{Conclusions}

- We obtained a collection of asphalt artifacts and determined the artifacts' age of internment through radiocarbon dating of wood, shell, or bone artifacts that directly contacted the asphalt artifacts, or that were found to be in close association (within the excavation) with the asphalt artifacts, thereby linking them to a date of internment.

- Radiocarbon dating shows that the artifacts range in age from $400 \mathrm{BP}$ to $4160 \mathrm{BP}$ (more than four times longer than the current design life of the Hanford Protective Barrier).
- Elemental analysis performed on a collection of asphalt artifact and asphalt analog samples shows strong evidence that the artifacts were manufactured from the asphalt analog samples collected in the field. This provides a clear link for comparing the chemical analysis of the asphalt artifacts to those of asphalt analog samples that will be used to develop an accelerated aging procedure.

- Qualitative IR analysis shows that the asphalt artifacts used in this study were not modified with pine pitch, a component that would have caused problems in performing quantitative IR analysis. 
- Several SHRP-MRL asphalts were analyzed using quantitative functional group analysis by IR. The results of these analyses agree well with data reported in SHRP literature.

- All of the appropriate derivitization reactions, for quantitative functional group analysis by IR, were performed on the asphalt artifacts and asphalt analog samples. Analysis of the data to quantify the various functional groups is ongoing.

- HPLC-SEC analysis of the asphalt artifacts and asphalt analogs, using radiocarbon-dating data, clearly establishes a relationship between the increase in the LMS as a function of duration of internment of the asphalt artifacts.

\subsection{Model Applications and Testing - M.J. Fayer (PNL)}

The objective of the Model Application and Testing task is to produce defensible simulation models of the hydrology of protective barriers that can be used to evaluate barrier performance for a minimum of 1000 years.

The record of monitoring at the FLTF exceeds 6 years. This time period presented a unique opportunity to test the ability of water balance models to predict water movement in barriers. Weighing lysimeter W4 was simulated using two water balance models, UNSAT-H and HELP. The UNSAT-H model was developed by this project to simulate water movement in protective barriers. The HELP model was developed by the EPA to evaluate landfills. The UNSAT-H model is more physically based, while the HELP model simplifies processes to enable quick and easy solutions on personal computers.

Lysimeter W4 is nonvegetated and received irrigation so that the total water added (irrigation + precipitation) equalled 2 times the monthly average precipitation during the first 3 years, and 3 times the monthly average during the second 3 years. The lysimeter was simulated four times with UNSAT-H using 1) standard parameters, 2) calibrated parameters, 3) heat flow, and 4) hysteresis.

The storage results in Table 2.6 show little difference among the four UNSAT-H simulations; the maximum root mean square (RMS) error was $23.7 \mathrm{~mm}$. In contrast, the HELP model predicted storage to be drastically different from the measurements; the RMS error was $97.6 \mathrm{~mm}$. With respect to soil water suction, the best match was obtained with the UNSAT-H simulation that included hysteresis. Because it was able to match suctions, this simulation was able to predict $15.3 \mathrm{~mm}$ of drainage, which was $52 \%$ of the measured drainage of $29.6 \mathrm{~mm}$ (Table 2.6). The other three UNSAT-H simulations predicted no drainage. HELP predicted drainage in every one of the 6 years, with a total of $1800 \%$ of the measured value. These results clearly indicate that hysteresis is a significant process in the behavior of water in a cover. They also indicate that the conceptual bases for the HELP model are inadequate for accurately simulating drainage through the protective barriers being designed by this program.

A closer look at the monitoring data from several lysimeters revealed a definite hysteretic behavior (independent of the simulation results above; Figures 2.8 and 2.9). For the first 
Table 2.6. Summary Statistics of Model Comparisons. Daily differences were calculated by subtracting predicted storage from measured storage. Measured drainage was $29.6 \mathrm{~mm}$.

\begin{tabular}{|c|c|c|c|c|c|}
\hline \multirow[b]{2}{*}{$\begin{array}{c}\text { Model } \\
\text { Description }\end{array}$} & \multicolumn{5}{|c|}{ Storage } \\
\hline & $\begin{array}{l}\text { RMS } \\
\text { Error }\end{array}$ & $\begin{array}{l}\text { Maximum } \\
\text { Difference }\end{array}$ & $\begin{array}{c}\text { Mean } \\
\text { Difference }\end{array}$ & $\begin{array}{c}\text { Median } \\
\text { Difference }\end{array}$ & $\begin{array}{c}\text { Cumulative } \\
\text { Drainage }\end{array}$ \\
\hline \multicolumn{6}{|l|}{ UNSAT-H } \\
\hline Standard & 23.6 & 75.8 & -0.9 & -6.0 & 0.0 \\
\hline Calibrated & 23.6 & 59.3 & 19.6 & 16.5 & 0.0 \\
\hline Heat & 23.4 & 80.2 & 1.6 & -3.4 & 0.0 \\
\hline Hysteresis & 23.7 & 74.8 & 3.0 & -2.0 & 15.3 \\
\hline Help & 97.6 & 264.4 & 84.9 & 73.1 & 537.0 \\
\hline
\end{tabular}

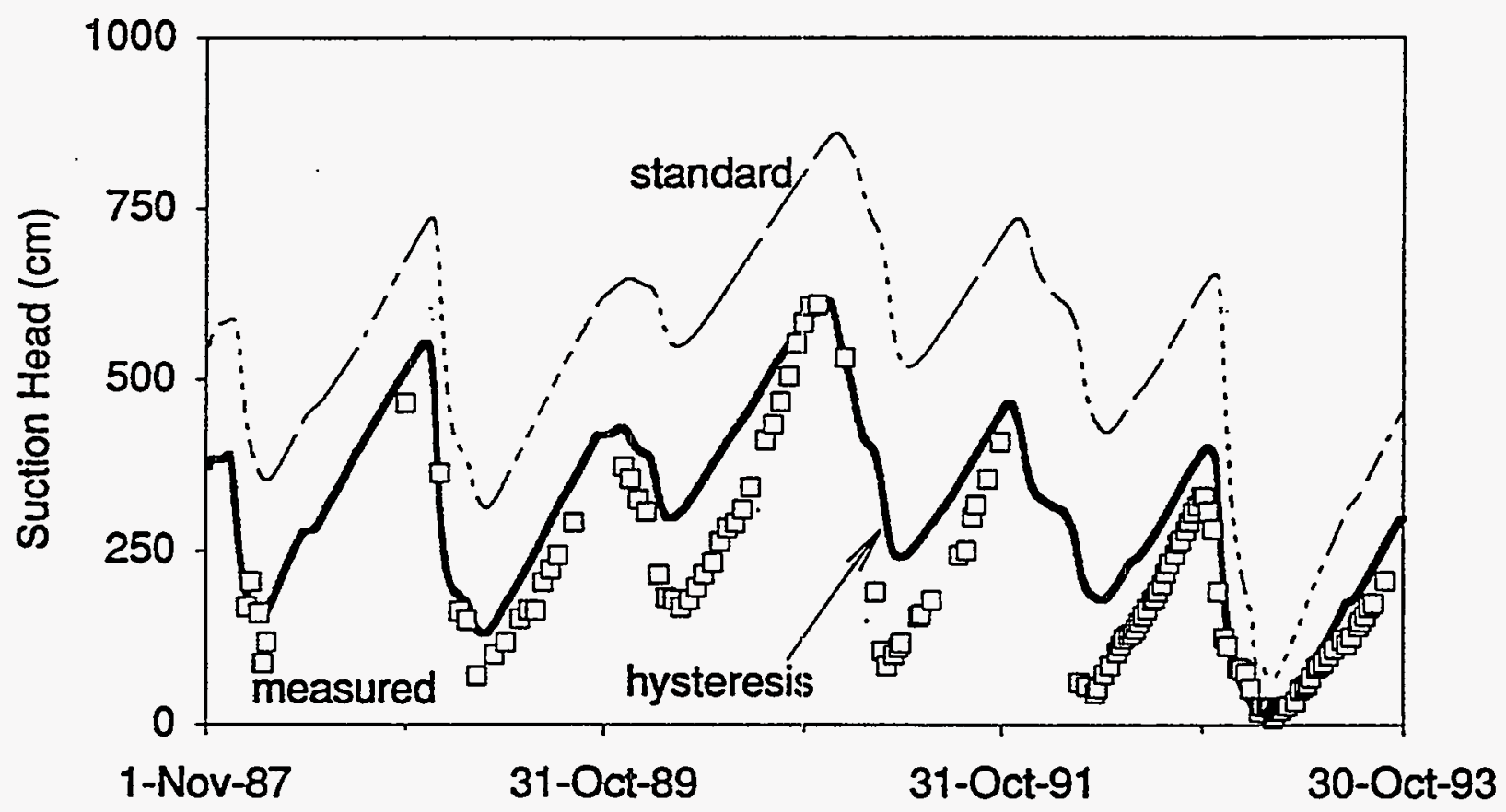

Figure 2.8. Comparison of Measured Suctions and Suctions Simulated with UNSAT-H Using Either Standard Parameters or Hysteresis 


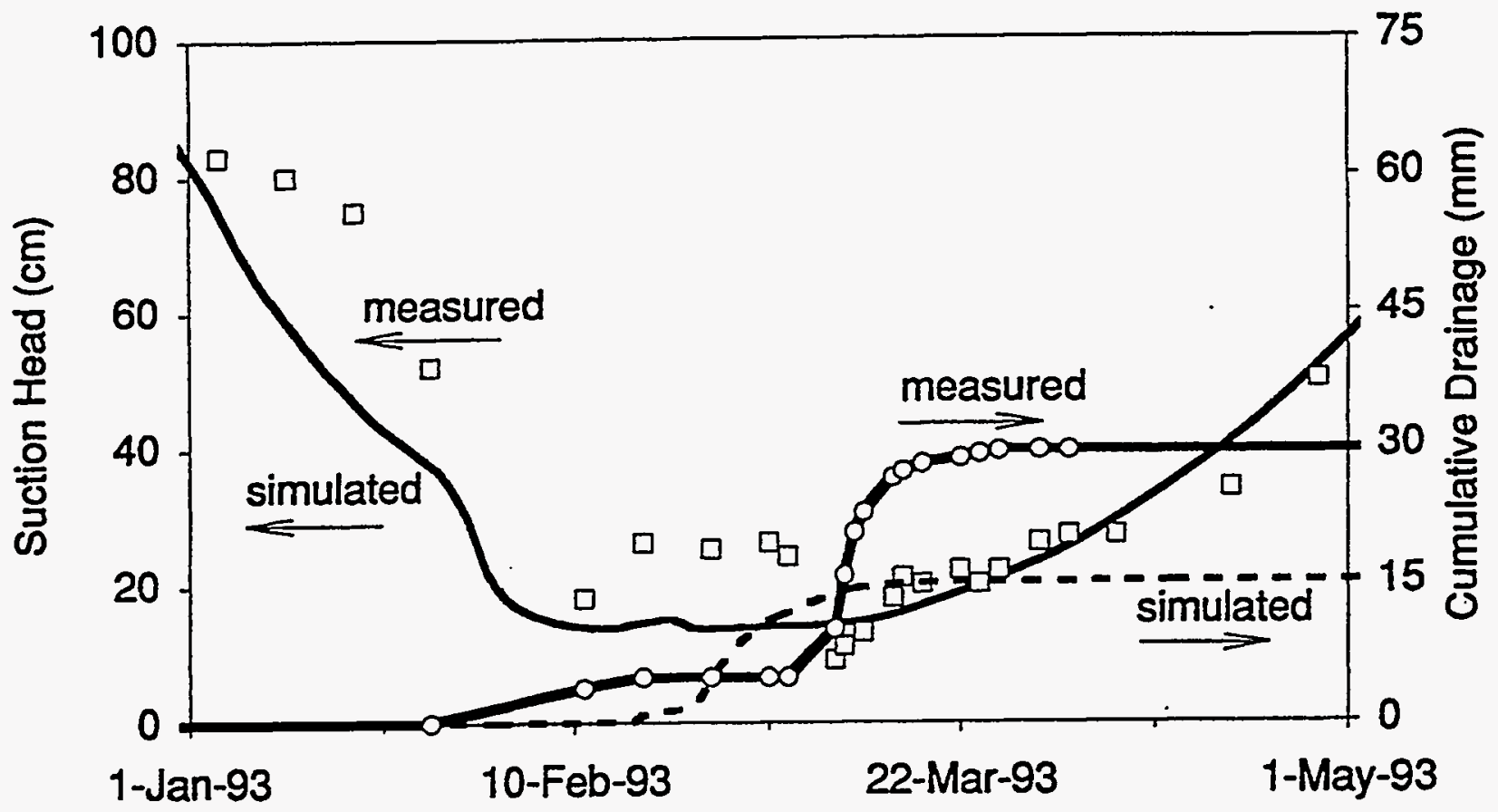

Figure 2.9. Comparison of Measured and Simulated Suctions and Drainage

5 years, the in situ retention data appeared to behave in a well-defined manner. In February 1993, an unusually large snowfall melted and caused the lysimeter to wet more than ever before. Once infiltration ceased and drying began, the in situ retention data ceased to behave as before. Rather, it behaved as if on a hysteretic drying curve. Furthermore, the in situ retention data were dissimilar to the laboratory data. The field and laboratory discrepancies could be largely explained by using a hysteretic retention model, suggesting that accurate assessments of barrier performance should consider hysteresis.

Additional work in FY 1994 included maintaining the UNSAT-H code, using the MSTS code on the original barrier edge problem (see discussion below), and modifying the MSTS code. The current version of UNSAT-H is Version 2.02. The original code was changed to correct identified errors, improve operation, and enable operation on Unix workstations and personal computers. UNSAT-H Version 2.02 was made available on the Internet using the PNL anonymous ftp server.

The MSTS computer code was identified for solving problems involving contaminant transport, air phase movement, thermal transfer, and problems in multi dimensions. It was used to solve the barrier edge problem reported in several previous barrier modeling documents. The results were very similar to previous solutions with the PORFLO-3 and TOUGH computer codes, demonstrating that MSTS could be used. Like UNSAT-H, the MSTS code is maintained on the Internet using the PNL anonymous ftp server. 
Efforts continued to add capability to the MSTS code, including the ability to simulate evaporation and snow accumulation and melt. Several subroutines were completed; the entire enhanced code is expected to be operational in FY 1995.

Lastly, plans for this task were outlined. They include completion of the evaporation and snow accumulation and melt routines; implementation of appropriate plant transpiration routines; and testing with data from vegetated lysimeters at the FLTF, the lysimeter at Hill Air Force.Base, and the prototype barrier. The goal is to have the modeling tools needed to assess barrier performance completed, documented, and available to the public by FY 1997.

\subsection{Resource Conservation and Recovery Act Comparisons}

\subsubsection{Experimental Plan and Con- struction Guidance for Hanford Protec- tive Barrier Test in A Wetter, Colder Climate at Hill Air Force Base, Utah - R.R. Kirkham and G.W. Gee (PNL)}

Permanent isolation surface barriers are needed to fully isolate buried waste materials from the general environment for long periods of time. Multi-layer surface barriers that use natural earthen materials overlying layers of rock and/or asphait are expected to reduce infiltration or deep percolation to less than $0.5 \mathrm{~mm}$ (0.02 in.) of water. The layering also reduces root penetration, preventing uptake and translocation of hazardous materials to the surface vegetation.

The development of these surface barriers is outlined in the document, Permanent
Isolation Surface Barrier Development Plan (Wing 1994). It is necessary to document the effectiveness of the barriers in the Hanford Site environment as it is now, and as it would be under a wetter environment that stresses the barrier (a possibility from historical climate analysis and projected by some global climate change scenarios).

The opportunity exists to test the design of the Hanford Protective Barrier in a wetter, colder climate at an existing lysimeter facility located at Hill Air Force Base near Salt Lake, Utah. The use of an existing lysimeter facility simplifies the construction effort and allows comparison of the Hanford Protective Barrier with an existing clay cap already being tested at the lysimeter site. The clay cap was designed to meet EPA RCRA guidelines.

Hill Air Force Base is located in northeast Utah (Figure 2.10) in the southwest part of the Weber Delta District, with portions of the base in both Weber County and Davis County. The base is situated on a broad plateau between the Great Salt Lake and the Weber River Valley. The plateau is part of the Weber Delta, formed as the Weber River flowed into Lake Bonneville [ancient Pleistocene lake with stable elevations of 1585 and $1463 \mathrm{~m}$ (5200 and 4800 feet)]. Surface soils are generally loamy fine sand or fine loamy sand. The soils are deep and well drained.

Summer weather is hot and dry (maximum temperature $40^{\circ} \mathrm{C}$ ), and winters are cold with a generally stagnant air mass (minimum temperature $-81^{\circ} \mathrm{C}$ ). Annual average rainfall is $48.8 \mathrm{~cm}$ (three times the Hanford average) and annual average snowfall is $182.4 \mathrm{~cm}$. 


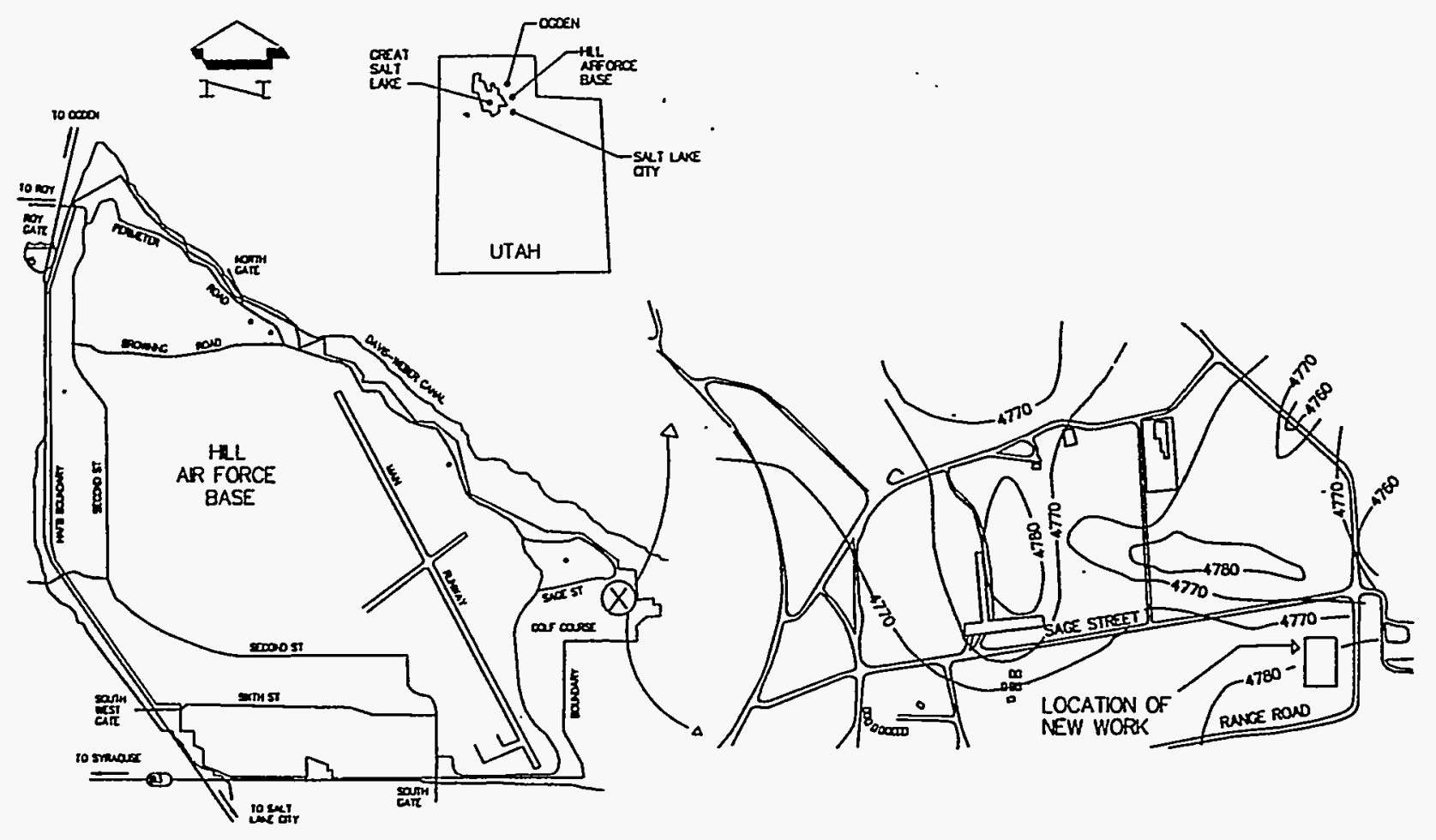

Figure 2.10. Location of Hill Air Force Base

The lysimeter is constructed from L-shaped fiberglass sections bolted together in the field. This is essentially the same design used by Los Alamos National Laboratory (LANL) researchers at Hill Air Force Base (Hakonson et al. 1993) (Figure 2.11). There are two differences in the lysimeter design: 1) the new vendor-supplied fiberglass panels will create a 2.4-m-deep (8-ft-deep) lysimeter without the addition of extension panels, and 2) subsurface soil layers within the lysimeter do not have the 4\% slope that was used in the LANL treatments. The bottom of the lysimeter will have two drainage collection areas created from 0.1-cm. (0.04-in.) reinforced geomembrane sheets laying on the lysimeter floor. The edges of the geomembrane sheet are raised on the ends and down the center of the long axis by draping the sheet material over $15-\mathrm{cm}$ (5.91-in.) PVC pipe. The geomembrane sheet was installed for two reasons: 1) because the side walls may act as preferential drainage pathways, flow down the side walls will be collected separately from the area over the geomembrane sheet, and 2) if the water table outside the lysimeter rises above the floor of the lysimeter, and if the seams fail (an unlikely occurrence), water entering the lysimeter would be collected as sidewall drainage and would not affect the primary drainage estimate obtained from the lysimeter area above the geomembrane sheet.

The lysimeter was completed in September 1994. The surface has been revegetated as shown in Figure 2.12. The measurement program is intended to continue for 3 years. During this time, data will be collected from both 


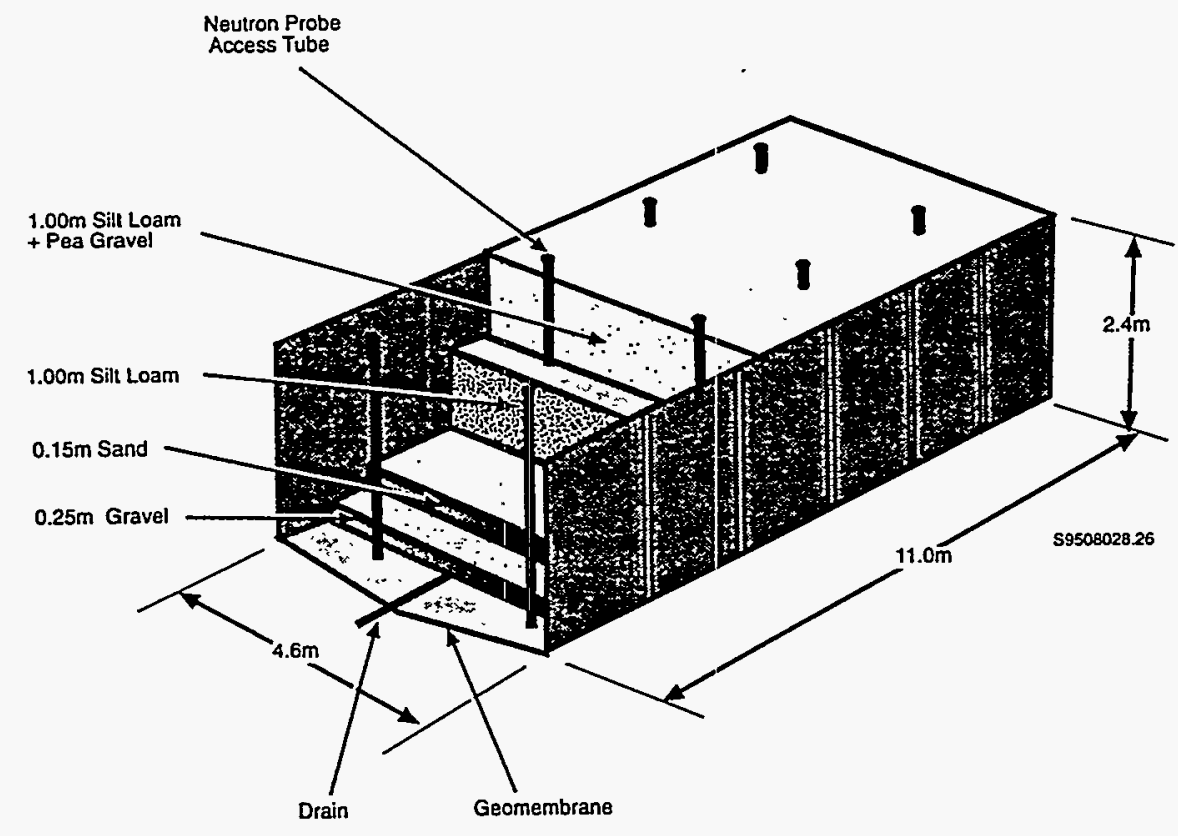

Figure 2.11. Staggered Cross Section of Lysimeter Located at Hill Air Force Base, Utah

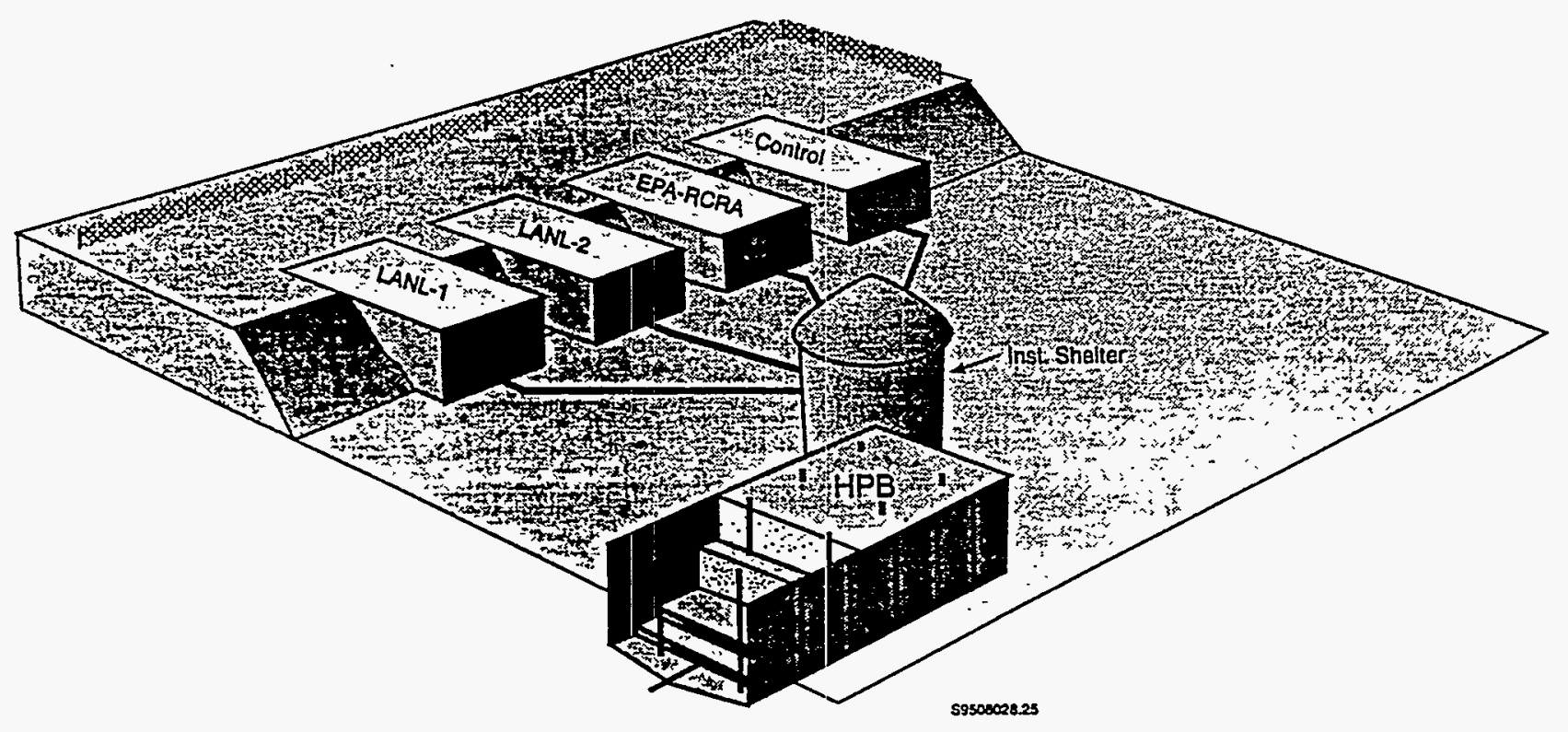

Figure 2.12. Perspective View of the Hanford Barrier Lysimeter and Existing Lysimeters at the Hill Air Force Base, Utah 
automated and manually read instrumentation. Descriptive plant measurements will be taken at least quarterly and used as input for vegetation parameters in model simulations. Soil properties were measured during construction; measurements will again be taken at yearly intervals. Similar to the vegetation data, these values are needed for initiation of soil parameters in the model validation effort, which is a separate task.

\subsection{Biointrusion Control}

The biointrusion control task encompasses efforts to understand and control the role of plants and animals on barrier surfaces (Link et al. 1994a). This section summarizes tasks related to establishing vegetation on the prototype surface and evaluating root characteristics of the FLTF lysimeter.

\subsubsection{Establishment of Vegetation on the Prototype Surface - S.O. Link (PNL)}

Plants will play a central role in the prototype barrier. Plants will extract, by transpiration, at least 2 times as much water from fine silt-loam soils as will be lost by soil evaporation alone. Plants will also minimize wind and water erosion (Link et al. 1994a). It is critical that a sustainable plant community be established on barrier surfaces. During the construction of the prototype barrier, revegetation efforts centered around preparations to plant shrub seedlings. This was done during the fall of 1994 after rains began.

Seeds of the shrubs Artemisia tridentata and Chrysothamnus nauseosus were collected from McGee Ranch on the Hanford Site on
December 23, 1993. The entire inflorescence of $A$. tridentata and the fruits of $C$. nauseosus were harvested and stored in plastic bags in the field. The material was transported to the Arid Lands Ecology laboratory facility, taken out of the plastic bags, and placed on table tops to dry. The material was stored this way in the dark and at room temperature until it was shipped to a nursery. The uncleaned, dry material was shipped to Plants of the Wild, Tekoa, Washington on March 11. The seed was cleaned by April 12 for germination. All the seed was sown on May 4. Germination was complete by about June 10 , with successful germination rates of $40 \%$ for $C$. nauseosus and $60 \%$ for $A$. tridentata. There are approximately 2500 seedlings of $C$. nauseosus and 7500 seedlings of $A$. tridentata. Seedlings (tublings) were grown in $164 \mathrm{~cm}^{3}\left(10 \mathrm{in.}^{3}\right)$ tubes.

The seedlings were shipped for planting in November 1994 on the prototype barrier surface. The surface of the prototype barrier was modified by hydroseeding a mix of grass seed, nitrogen, and organics.

The developing plant community will be assessed to determine the success of shrub establishment, grass establishment from seed, and the incursion of alien species such as Salsola kali during fiscal year 1995. Revegetation in the surrounding areas near the prototype barrier was completed in November 1994 by hydroseeding. The occurrence, growth, and ability of plants to extract water will be monitored on the prototype barrier surface and along the toe of the barrier. 


\subsubsection{Root Characteristics of the FLTF Lysimeters - S.O. Link, C.A. McAllister, J.C. Ritter, and G.W. Gee (PNL)}

Plants strongly control soil water storage and will play a central role in the surface hydrology of the prototype barrier. The primary purpose of a barrier is to prevent water from draining into the waste. The FLTF lysimeters have been used to document the effect of various soil, vegetation, and precipitation regimes on soil water storage (Gee et al. 1993b). Vegetation will remove, by transpiration, at least two times the amount of water from the soil column than is lost by soil evaporation alone. It is important to develop simulation models of transpiration that can be used to predict how much water plants can remove from surface soils under extreme effects. The simulation of this process will aid in developing confidence in the capability of the barrier to prevent drainage over long time periods. A weakness in current simulation models is the lack of adequate information on the rooting characteristics of plants likely to inhabit barrier surfaces. In earlier reports on the simulation of plant transpiration from the FLTF lysimeters, we had to rely on published rooting characteristics of $A$. tridentata from locations and soils that were far removed and different from the conditions of the FLTF lysimeters (Link et al. 1993). The purpose of this study was to identify root characteristics from a subset of the FLTF lysimeters that can be used to more accurately simulate the dynamics of soil water storage. Lysimeters were carefully dismantled in preparation for new studies. During this process, root cores were taken from the lysimeters to provide information on root biomass density and root length density with depth. We report root biomass data on one replicate from each of four lysimeters at six depths.

\section{Methods}

In spring 1994, root samples were taken from the FLTF lysimeters. Five sampling areas in each lysimeter were chosen, two near $A$. tridentata, two near grass stands, and a randomly chosen fifth area. Sampling was done in circular patterns approximately $0.5 \mathrm{~m}$ in diameter. The sampling areas were labeled $A, B$, $C, D$, and $E$, with $A$ being northernmost and $B, C, D$, and $E$ going clockwise from north. A 7.6-cm-high, 7.6-cm-dia. aluminum pipe was driven into the ground in each sample area. The core volume of the pipe is $347 \mathrm{~cm}^{3}$. Soil was removed around each pipe and the pipe was sheared at the bottom. The sample was then placed in double plastic bags. After the remaining soil was excavated to the next level, the pipes were again driven into the same sample areas. Samples were taken randomly within each area at each depth.

Samples were stored in double plastic bags and kept in a freezer. Soil samples were mixed thoroughly and subsampled for root separation. The sampled soil volume was $100 \mathrm{ml}$. Roots were separated from soil samples with a Gillison's hydropneumatic root washer. One $100-\mathrm{ml}$ sample was placed into a tube on the root washer. The transfer pipes were placed on top of the tube, each with a $\mathbf{5 3 0}$ primary sieve attached. Each timer was set for 10 minutes. When the timers shut off, the 530 primary sieves were removed and inverted over a 410 sieve (a finer sieve). Roots and organic material were then washed from the primary sieve onto the bottom of the 410 sieve. Using tweezers, organic material and roots were 
separated from one another. Roots were placed in a plastic Petri dish filled halfway with water. When all roots had been removed, the lid of the Petri dish was labeled with the soil sample information and the dish was placed in the freezer.

Root samples were.placed in tared glass vials that were loosely capped and dried for at least 48 hours at $48^{\circ} \mathrm{C}$ in a convection oven. The vials were then capped and weighed using a Mettler balance. This procedure was followed to prevent water vapor from rehydrating the root samples. Data are presented as the oven-dried root biomass density, computed by dividing root mass by the soil volume $(100 \mathrm{ml})$.

\section{Results and Discussion}

Root biomass density data are of the same magnitude with depth as reported for similar soils and plants at McGee Ranch (Link et al. 1994b). The relatively high density values (>1 $\mathrm{mg} \mathrm{cm}^{-3}$ ) observed at three locations are most likely the result of long and thick roots in the sample (Table 2.7). Most roots were of a consistent size and less than $0.5 \mathrm{~mm}$ in diameter.

Table 2.7. Oven-Dried Root Biomass Density ( $\mathrm{mg} \mathrm{cm}^{-3}$ ) in the FLTF Lysimeters. Data are for the " $A$ " location on the lysimeter surfaces.

\begin{tabular}{|c|c|c|c|c|}
\hline \multirow{2}{*}{$\begin{array}{c}\text { Depth } \\
\text { (cm) }\end{array}$} & \multicolumn{2}{|c|}{ Lysimeter } & \multirow[b]{2}{*}{ D-07 } & \multirow[b]{2}{*}{ D-14 } \\
\hline & D-02 & D-04 & & \\
\hline 4 & 0.036 & 0.049 & 0.153 & 0.237 \\
\hline 24 & 1.834 & 0.668 & 0.116 & 0.215 \\
\hline 55 & 0.634 & 0.080 & 0.148 & 0.160 \\
\hline 85 & 0.110 & 1.705 & 0.146 & 0.294 \\
\hline 116 & 0.346 & 0.089 & 0.196 & 1.258 \\
\hline 141 & 0.258 & 0.562 & 0.078 & 0.427 \\
\hline
\end{tabular}

Remaining work is required to process roots from the other four sample locations on each lysimeter. Such data will provide statistical estimates of root biomass with depth in each lysimeter. Work is also under way to measure root length density. Because these data are difficult to obtain, root biomass density will be related to root length density over a range of biomass values for a subsample of roots, thus permitting predictions of root length density from root biomass density for all samples. Root length density data are commonly used in simulation models of transpiration.

\subsection{Long-Term Performance}

\subsubsection{Climate Change - K.L. Petersen (PNL)}

The goal of the BDP is to provide defensible evidence that final barrier design(s) will adequately control water infiltration, plant and animal intrusion, and wind and water erosion for a minimum of 1000 years, and will isolate wastes from the accessible environment and, through the use of markers, warn inadvertent human intruders. In addition to the work described in previous sections, analyzing the performance and stability of natural barrier analogs that have existed for several thousand years and reconstructing climate changes occurring over the past 10,000 years and longer will provide insight into bounding conditions of possible future changes.

Petersen, Chatters, and Waugh (1993) detail a research approach for obtaining defensible projections of climate parameters based on studies of current climate, past climate, and projected future climate. The overall objective of the Long-Term Climate Change task is to accomplish the following: 
- Obtain defensible probabilistic projections of the long-term climate variability in the Hanford Site and the Pasco Basin region

- Develop several test-case climate scenarios that bracket the range of potential future climate

- Use the climate scenarios to test and model barrier performance.

Climate affects all aspects of barrier performance. Soil water movement will be affected by changes in precipitation, temperature, and vegetation. Climatically induced changes in plant and animal communities will affect the potential for biointrusion, and surface stability will be affected by changes in wind patterns.

The first key finding of the FY 1994 work conducted under this task comes from a $+75,000$-year pollen record obtained near Goldendale, Washington, located southwest of the Hanford Site. Based on the record, the long-term mean annual precipitation in the Columbia River Basin is estimated to have ranged between $50 \%$ to $75 \%$ of modern and $130 \%$ of modern levels, while temperatures have ranged from $7^{\circ} \mathrm{C}$ to $10^{\circ} \mathrm{C}$ below to $2^{\circ} \mathrm{C}$ above modern levels. There is no evidence that the long-term precipitation averages ever reach 3 times that of present day (the amount taken as an upward natural bounding range for testing and modeling the prototype barrier design). Such climatic records give confidence that climatic cycles for 1000 or more years into the future in the Columbia Basin should also be bounded by the 3 times normal precipitation.

A second key finding is that although the range of precipitation in the Columbia Basin is tightly bracketed, changes in seasonality of precipitation have occurred in the past. These changes have resulted in fluctuations between Artemisia shrub-steppe and bunchgrass steppe in the Hanford Site region. In the future, such changes in seasonality could impact the vegetation and animal communities that might occupy protective barrier surfaces.

Funding for this task was terminated in FY 1994 in response to the recommendations made by participants at the Value Engineering workshop convened in February 1993. However, based on the same recommendation, other programs requiring climate information to support the remediation and management of wastes at the Hanford Site will be approached to fund the remaining tasks identified in the climate change study plan.

\subsubsection{Natural Analogs - S.O. Link (PNL), W.J. Waugh (RUST), and K.L. Petersen (PNL)}

Natural analogs are ecosystems or soil structures that exhibit characteristics similar to that expected for the barrier over a long time period. Such natural systems allow us to address hypotheses about potential barrier function in well-established conditions. It is important to draw inferences based on natural analogs to aid in barrier design and increase confidence in barrier function. Simulation modeling based on newly constructed test barriers is not likely to simulate barrier function after pedogenisis and plant community development. These processes evolve over hundreds to thousands of years. Studies of natural analogs have been conducted since the inception of the barrier program and have provided insight into long-term functional characteristics of the barrier. A review of natural analog studies at 
Hanford was published during FY 1994

(Waugh et al. 1994).

Layered exposures of glacial-

flood-deposited gravels mantled with silt or sand that resemble contemporary barrier designs were examined (Waugh et al. 1994). Bergmounds, another anomaly left by cataclysmic glacial floods, were also examined as analogs of surface gravel. The following design considerations emerged from a moderate characterization of these deposits: 1) a capillary moisture barrier design consisting of a fine-textured topsoil overlying a mixed layer of gravel and coarse sand (pitrun gravel) may be more stable than designs featuring graded, well-sorted soil, sand, and gravel layers; 2) soil development processes that can alter soil hydraulic properties, such as particle aggregation and illuviation of soluble salts and colloids, will likely take place on waste covers; 3) the depth and dispersion of carbonate accumulation may provide an indication of past soil water movement in layered soils; 4) disturbances causing deep-rooted perennial vegetation to be replaced by shallow-rooted, short-lived species could reduce plant water extraction and trigger drainage; and 5) spatial patterns in surface water infiltration, water retention, and evapotranspiration may evolve on waste covers in response to soil formation processes and clumped plant distribution patterns (Waugh et al. 1994).

A study of the effects of spatial variation in soils and plants on soil water storage dynamics at McGee Ranch was published in FY 1994 (Link et al. 1994b). McGee Ranch is the source of the fine silt-loam soils used to create the uppermost layer on the prototype barrier. This site is dominated by shrubs. Grayia spinosa grows atop coppice dunes that are 30 to $50 \mathrm{~cm}$ tall. A. tridentata, perennial grasses, and forbs grow predominantly in the interhummock swales. Numerous interhummock swales were sparsely vegetated without shrubs. It is possible that barrier surfaces could develop similar variations that may influence soil water patterns on the surface. The relationship between topography, vegetation, and soil water storage dynamics was determined at $\mathrm{McGee}$ Ranch. Variation in soil water storage was more closely related to variation in vegetation than to topographic conditions. The implication for the hydrologic modeling of barriers is that accurate representations of soil water dynamics on the surface will need to account for vegetational patterns (Link et al. 1994c).

\subsection{Technology Transfer}

\subsubsection{Technology Integration and Transfer}

During FY 1994, a number of activities were conducted to integrate with and transfer surface barrier technology to end users as well as to other interested individuals and organizations. These activities are discussed below.

\subsubsection{Barrier Development Program Documentation}

Progress leading to a final barrier design continues to be documented. The documentation includes the results of all barrier development, research, demonstration, and testing activities conducted throughout the life of the BDP. This information serves as the foundation on which technically defensible final designs are based.

The design and construction of the prototype barrier during fiscal years 1993 and 1994 has enabled the results of research-oriented 
activities to be used to prepare various engineering-related documents. These documents include 1) definitive design drawings, 2) construction specifications, 3) a construction quality assurance plan, 4) a design basis document, and 5) a constructability report. These engineering-related documents will serve as a useful model for the design and construction of future barriers.

Documents produced as a result of barrier development activities continue to be cleared for public release, published, and disseminated to interested individuals and organizations both onsite and offsite. Currently, over 90 barrierrelated documents have been published. Appen$\operatorname{dix} B$ contains a list of barrier documents pub- . lished to date.

\subsubsection{Videotape Production}

In addition to the written documents, a videotape of the BDP was produced this fiscal year. The videotape documents the approach being taken to develop long-term surface barriers for the Hanford Site. A summary of some of the barrier development tasks and activities that have been conducted over the years is provided. Graphic animations are used to demonstrate how the barrier functions. Additionally, the videotape documents the design, construction, and testing/monitoring of the prototype barrier that was completed in August 1994.

This videotape will be a valuable resource to potential customers of barrier technology and to other interested parties by demonstrating how barriers function and how they are constructed.

\subsubsection{Consultation on Barrier- Related Topics}

During FY 1994, members of the BDP have provided information and consultation on barrier design and construction issues to a number of interested individuals and organizations. For example, designers at DOE's Rocky Flats Site have been in contact with Hanford's BDP throughout this fiscal year to acquire information and gain insights to assist them in designing a barrier for one of their waste sites. In addition, scientists and engineers supporting the design and performance monitoring of the Rocky Flats barrier have solicited information on the Hanford approach to barrier performance monitoring. Other individuals and organizations from across the country and the world also have requested information pertaining to various aspects of the Hanford Site's barrier development effort.

Members of the BDP also have been involved in the planning for the acquisition of the various materials that will be used to construct barriers at the Hanford Site. The BDP engineers are helping to address some fundamental questions, such as the following:

- Do barrier construction materials of suitable quality exist in adequate quantities to support the Hanford Site's environmental restoration plans?

- Are additional characterization activities needed to finalize the quantity estimates of barrier construction materials or to identify new sources of materials? 
- Has the appropriate documentation been completed to support excavation of barrier construction materials?

- How will potential impacts associated with cultural resource and threatened and endangered species concerns be mitigated or resolved?

- How will the barrier construction materials be transported from the borrow pits or quarries to the waste sites where barriers are being constructed?

- Will the current transportation infrastructure need to be improved or engineered to handle the loads and volume of traffic required to support the construction of protective barriers?

- If needed, can modifications to the infrastructure be planned, procured, and installed in a timely manner to support environmental restoration activities?

The answers to these questions are critical to support the timely construction of surface barriers at the Hanford Site.

\subsubsection{Technology Transfer}

As mentioned previously, surface barrier technology is of interest to other DOE sites, particularly those located in arid climates. Collaborative efforts already have been fostered with engineers and scientists from other field offices who are either working on or have an interest in barrier-related issues. Workshops have been convened, special topics meetings organized, and papers presented at DOEsponsored symposia and workshops such as the
Sixth National Technology Information Exchange convened in Kennewick, Washington, in May 1994. In addition, members of the BDP have served on Technical Support Groups sponsored by DOE-Headquarters' Office of Technology Development.

Efforts to transfer barrier technology to individuals and organizations outside the DOE complex also have been made during the past year. For example, a number of papers have been presented at several national and international technical conferences and symposia. In addition, papers have been submitted, published, or scheduled to be published in various technical journals.

In addition to the activities noted above, efforts were made during FY 1994 to prepare for an international symposium to be held in Pasco, Washington, in November 1994. The objective of this symposium was to bring together individuals from around the world who are working on surface barriers and other in situ remediation technologies. The conference included several days of presentations and a tour of Hanford's barrier field test sites, including the prototype barrier. A proceedings document of the presented papers has been published and was distributed to symposium attendees. A number of individuals on the BDP participated in this symposium. G. W. Gee and N. R. Wing chaired the symposium and served as editors of the symposium proceedings. ${ }^{(a)}$

(a) G. W. Gee and N. R. Wing, editors. 1994. In-Siru Remediation: Scientific Basis for Current and Future. Technologies, Parts 1-2. Thirty-Third Hanford Symposium on Health and the Environment, November 7-11, 1994, Pasco, .Washington. Battelle Press, Columbus, Ohio. 


\subsection{References}

Campbell, G. S., and G. W. Gee. 1986.

"Water Potential: Miscellaneous Methods." In Methods of Soil Analysis, ed. A. Klute, Part 1. 2nd ed. Agronomy 9:619-633.

Daniel, D. E. 1994. "Surface Barriers: Problems, Solutions, and Future Needs." In ThirtyThird Hanford Symposium on Health and the Environment: In-Situ Remediation: Scientific Basis for Current and Future Technologies, pp. 441-487. Battelle Press, Columbus, Ohio.

Gee, G. W., L. L. Cadwell, H. D. Freeman, M. W. Ligotke, S. O. Link, R. A. Romine, and W. H. Walters, Jr. 1993a. Testing and Monitoring Plan for the Permanent Isolation Surface Barrier Prototype. PNL-8391; Pacific Northwest Laboratory, Richland, Washington.

Gee, G. W., D. Felmy, J. C. Ritter, R. R. . Kirkham, S. O. Link, J. L. Downs, and M. J. Fayer. 1993b. Field Lysimeter Test Facility: Status Report IV. PNL-8911, Pacific Northwest Laboratory, Richland, Washington.

Gee, G. W., H. D. Freeman, W. H. Walters, Jr., M. W. Ligotke, M. D. Campbell, A. L. Ward, S. O. Link, S. K. Smith, B. G. Gilmore, and R. A. Romine. 1994. Hanford Prototype Surface Barrier Status Report: FY 1994. PNL-10275, Pacific Northwest Laboratory, Richland, Washington.

Hakonson, T. E., K. L. Manies, R. W. Warren, K. V. Bostick, G. Trujillo, J. S. Kent, and L. J. Lane. 1993. "Migration Barrier Covers for Radioactive and Mixed Waste Landfills." In The Proceedings of the Second Environmental Restoration Technology Transfer Symposium, San Antonio, Texas.
Hook, W. R., N. J. Livingston, Z. J. Sun, and P. B. Hook. 1992. "Remote Diode Shorting Improves Measurement of Soil Water by Time Domain Reflectometry." Soil Sci. Soc. Am. J. 56:1384-1391.

Ligotke, M. W. 1993. Soil Erosion Rates Caused by Wind and Saltating Sand Stresses in a Wind Tunnel. PNL-8478, Pacific Northwest Laboratory, Richland, Washington.

Ligotke, M. W., and D. C. Klopfer. 1990. Soil Erosion Rates from Mixed-Soil and Gravel Surfaces in a Wind Tunnel. PNL-7435, Pacific Northwest Laboratory, Richland, Washington.

Link, S. O., R. N. Kickert, M. J. Fayer, and G. W. Gee. 1993. A Comparison of Simulation Models for the Prediction of Soil Water Dynamics in Bare and Vegetated Lysimeters. PNL-8675, Pacific Northwest Laboratory, Richland, Washington.

Link, S. O., L. L. Cadwell, C. A. Brandt, J. L. Downs, R. E. Rossi, and G. W. Gee. 1994a. Biointrusion Test Plan for the Permanent Isolation Surface Barrier Prototype. PNL-9411, Pacific Northwest Laboratory, Richland, Washington.

Link, S. O., W. J. Waugh, J. L. Downs, M. E. Thiede, J. C. Chatters, and G. W. Gee. 1994b. "Effects of Coppice Dune Topography and Vegetation on Soil Water Dynamics in a Cold-Desert Ecosystem." Journal of Arid Environments 27:265-278. 
Link, S. O., W. J. Waugh, and J. L. Downs. 1994c. "The Role of Plants on Isolation Barrier Systems." In Thirty-Third Hanford Symposium on Health and the Environment: In-Situ Remediation: Scientific Basis for Current and Future Technologies, pp. 561-592. Battelle Press, Columbus, Ohio.

Myers, D. R., and D. A. Duranceau. 1994. Prototype Hanford Surface Barrier: Design Basis Document. BHI-00007, Bechtel Hanford, Inc., Richland, Washington.

Petersen, K. L., J. C. Chatters, and W. J. Waugh. 1993. Long-Term Climate Change Assessment Study Plan for the Hanford Site Permanent Isolation Barrier Development Program. WHC-EP-0569 Rev. 1, Westinghouse Hanford Company, Richland, Washington.
U.S. Department of Energy (DOE). 1994. Constructability Report for the 200-BP-1 Prototype Surface Barrier. DOE/RL-94-76, U.S. Department of Energy, Richland Operations Office, Richland, Washington.

Waugh, W. J., J. C. Chatters, G. V. Last, B. N. Bjornstad, S. O. Link, and C. R. Hunter. 1994. Barrier Analogs: Long-Term Performance Issues, Preliminary Studies, and Recommendations. PNL-9004, Pacific Northwest Laboratory, Richland, Washington.

Wing, N. R. 1994. Permanent Isolation Surface Barrier Development Plan.

WHC-EP-0673, Westinghouse Hanford Company, Richland, Washington. 


\section{Appendix A}

Supporting Letters From Dr. David Daniel 


\author{
DAVID E. DANIEL \\ CIVIL ENGINEER \\ 7608 YAUPON DRIVE - AUSTIN, TEXAS 78759 \\ Telephone and Telefax: (512) 219-0698
}

August 30, 1994

N. R. Wing

IT Corporation

345 Hills Street

Richland, WA 99352

Purchase Order: MJF-SCV-298796

Dear Mr. Wing:

This brief report will serve to summarize my comments concerning the prototype barrier program at Hanford. Under the above-referenced purchase order, I have reviewed various reports that have been sent to me concerning the prototype barrier, visited the site in April and August of this year, visited the test facility at Hill AFB, conducted strength tests on the fluid applied asphalt, and analyzed the static and seismic stability of the prototype barrier. I have also written to you concerning the long-range needs of the barrier program (letter of August 19, 1994). Results of testing on the fluid applied asphalt, and of stability analyses for the prototype, were summarized in a report dated August 29, 1994.

I'll make my comments brief and just focus on two issues: (1) where your are, and (2) where you're going with the program. The prototype barrier is, to my knowledge, the largest and most sophisticated surface barrier ever constructed in an arid environment. The design is very well thought-out, and construction seemed to go smoothly. The thorough work done by the project team over the last few years has come together very nicely to produce a sophisticated, multiplecomponent, redundant barrier system. If there is a better thought-out surface barrier anywhere in the world, I am not familiar with it.

I am rather surprised at the total cost of the facility now that I see it fully in place; it is much less expensive than I would have originally envisioned. The cost is on a par with that of municipal waste landfill covers in places like Long Island, New York. I believe that surface barriers like the prototype that has been constructed can be extremely effective, very economical (especially considering the alternatives), and very beneficial in terms of providing effective environmental protection in a timely, cost-effective manner.

The only concern that I have about the prototype barrier is with creep of the fluid applied asphalt. I strongly recommend that you monitor slope movements, per our discussions, to determine whether there is any potential problem with creep-induced movements. If the data suggest that movements are occurring, I recommend further investigations be initiated to better document the creep characteristics of the fluid applied asphalt and of the deformations within the prototype. The lluid applied asphalt serves a very useful hydraulic purpose; it is an important component of the prototype barrier and should remain a strong candidate material for future barriers, provided that creep is not, or can be made not to be, a problem. In the future, creep can be controlled by using a wider "overhang" of basalt or soil beyond the limits of the fluid applied asphalt to buttress and thereby to contain the fluid applied asphalt and overlying materials. 
A question can be asked about why the potential problem with creep of the fluid applied asphalt was not identified earlier. I do not feel that it is anyone's fault. I, among others, did not recognize that creep could be a problem until I saw the actual material. The asphaltic liners that I have seen before are much stiffer and less vulnerable to creep than the material used at Hanford. In defense of the material used at Hanford, the tremendous ductility and resiliency of the material makes it ideal as a self-sealing hydraulic barrier. The manufacturer of the fluid applied asphalt has had the material tested for interfacial shear with sand, and the strength properties reported by the testing laboratory were quite high. There was no indication prior to construction that low strength or creep might be a problem. I think that we can attribute the possible problem to use of a rather new material in a new application. In my view, the purpose for constructing the prototype was, in large part, to identify any unforeseen problems. The prototype was successful in identifying a previously unforeseen problem that warrants further evaluation in the future.

I do not have any comments on the instrumentation plan for the prototype, other than to note that the instrumentation scheme is comprehensive but does not constitute overkill. The instruments are very sophisticated, but in my judgment the number of field instruments and degree of sophistication of the field instrumentation are about right. If the potential for creep is monitored on slopes, I believe that the instrumentation program will provide a clear picture of how the barrier is performing and will document why it is working. It is very important to monitor the prototype for at least several years so that long-term effects are taken into account as best as possible.

The work at Hill AFB is extremely valuable in validating the water balance concepts for the prototype barrier under changed-climate scenarios. I highly recommend that this work continue. It is very cost effective.

In terms of future work, I have some suggestions to offer. The need for graded barriers at Hanford is very high, and I think that identification of suitable designs, and appropriate verification of those designs, is the highest priority for future work. I believe that very cost effective barrier materials, such as geomembranes and geosynthetic clay liners, should be given stronger consideration for graded barriers, where the need for an extremely long service life may not be as acute as it was for the prototype barrier. Field tests, particularly on geosynthetic clay liners, are appropriate. I also think that you should give high priority to determination of the effects of differential subsidence upon surface barriers - it will be very important to quantify how much distortion the barriers can safely withstand so that judgments can be made concerning the need for physical stabilization of the waste prior to construction of a surface barrier. Field-scale tests to study the effects of subsidence are recommended.

Finally, I hope that you will do all that you can in the months and years ahead to make others aware of the data from the prototype barrier. It is a very valuable resource that has broad applicability within the DOE community and outside of it, as well. I encourage you to give a high priority to regular transfer of results to potential users.

I have enjoyed working with you and the other members of the barrier team this year. Please feel free to call if you have any questions.

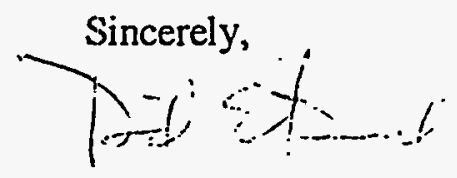

David E. Daniel 
COLLEGE OF ENGINEERING

THE UNIVERSITY OF TEXAS AT AUSTIN

Department of Ciril Engineering 'A ustin, Texas 78712-1076

Geotechnical Engineering • (512) $471-4929 \cdot F A X(512) 471-6548$

August 19, 1994

Mr. N. Richard Wing

IT Corporation

345 Hill Street

Richland, WA 99352

Dear Mr. Wing:

\section{SURFACE BARRIERS AT HANFORD: COSTS, RISKS, AND FUTURE DIRECTIONS}

I am writing to follow up on my recent peer review of the surface barrier program and to express concerns about the future of the surface barrier program at Hanford. My external reviews of Hanford's programs have led me to conclude that enormous sums of money will be spent at Hanford on surface barriers. The opportunity exists now to plan and verify surface barrier strategy that would save hundreds of millions of dollars. The window of opportunity that presently exists will only last for a few years; it is important to plan and to act now. I would like to recommend an approach that I believe could yield substantial savings in budget and schedule for Hanford.

As you probably know, I have been heavily involved in waste containment issues nationally and internationally for the past 15 years. I have been the EPA's principal researcher for natural materials used for. liners and caps in waste containment facilities and am currently a co-principal investigator on a \$900K EPA project, "Field Performance and Waste Containment Facilities." I edited the 1993 book Geotechnical Practice for Waste Disposal, which presents the knowledge base for surface barriers and other waste containment components. I have taught more than 100 training courses (about half under EPA sponsorship) in the U.S. and Europe on liners and surface barriers. These seminars have been attended by more than 10,000 scientists and engineers. I serve on review teams for DOE's In Situ Remediation Integrated Program and Burial Waste Integrated Demonstration. I have been asked to serve on the newly formed Board on Energy and Environmental Systems, National Academy of Sciences. I feel fortunate to have had the opportunity to be involved in so many diverse groups and believe that I have a good understanding of the "big picture" in terms of surface barriers used for all types of waste remediation, including the contaminated areas at Hanford.

\section{SURFACE BARRIERS: SOME SUCCESSES, MANY FAILURES}

Surface barriers which are also called "caps" or "covers," have been used for many years for closing landfills. Non-radionctive waste landfills are regulated by the U.S. EPA under the Resource Conservation and Recovery Act (RCRA). The caps are often called "RCRA caps." The EPA has published detailed guidelines on how a cap should be designed.

The first RCRA caps were multi-component caps buili starting in about 1982 over hazardous waste landfills. The caps contain plastic membrane liners and wet, compacted clay. The RCRA cap is not unrensonable for humid sites (the industry joke is that the RCRA cap was conceived by EPA in Washington, D.C., and only applies inside the beltway). A RCRA cap is not appropriate for Hanford because: (1) the wet clay' would dry and crack, and (2) the service life of the plastic liner is too short. 
Non-hazardous waste is also regulated by EPA under RCRA and is often termed "municipal solid waste" (MSW). Rules for MSW caps were established in 1993. The MSW cap consists of 6 inches of soil for erosion protection underlain by a plastic membrane, which in turn is under lain by 18 inches of soil. Many experts in the industry believe that this cap is technically inadequate (grossly inadequate, not just slightly inadequate) and represents a compromise in environmental protection for the sake of short-term savings in dollars. The criticism is so strong that many states are enforcing far more stringent requirements for MSW landfills.

Clean-up of old waste sites is regulated by EPA under Superfund. RCRA rules may be applicable or relevant and appropriate (the so-called ARARs principle). Even though RCRA may not apply to buried waste or to the cleanup, RCRA rules must still be considered and, if relevant and appropriate, are very pertinent. I do not feel that Hanford can or should escape the EPA regulatory umbrella.

While some RCRA caps have worked well, many have not. The key points are:

- A standard RCRA cap intended for hazardous waste is not going to work in an arid climate over a long time period (hundreds to thousands of years)

- A standard RCRA cap intended for non-hazardous waste (MSW) may not work anywhere and certainly is not appropriate for long-term waste containment in Hanford

- RCRA requirements should be considered and may be enforceable under the ARARs principle

- If one were to simply pull a standard RCRA cap design off the stielf and use it at Hanford, there is a high probability that the cap would not work and that one would have to cap the cap (i.e., remediate the remediation).

\section{SURFACE BARRIERS: THEIR ROLE AT HANFORD}

1. There are basically two ways to deal with radionuclides in the subsurface: (a) remove them, or (b) leave them in place but limit their migration potential via engineered containment.

2. The cost of exhuming radioactively contaminated soil is extremely high. Exhumation involves substantial risk to workers. As we learn more about the removal option, it seems-likely that the costs will get higher (not lower), and concerns over exposure to workers greater (nor less). The containment option, which is cheaper and safer, is likely to become much more attractive as remediation progresses.

3. A surface barrier will be crucial to waste containment at Hanford. The technical community, regulators, public, and (I hope) DOE will insist on limiting surface water infiltration and biointrusion at containment sites with a surface barrier. Studies at Hanford have shown that without a surface barrier, approximately half of the 6 inches of annual precipitation percolates into the sandy soils. This infiltration works out to 
be about 80,00 gallons of water per acre per year. If this liquid contacts soluble contaminates, leachate with migration potential results. A good surface barrier will greatly minimize this potential.

4. Although good estimates of the number of acres of surface barriers required at Hanford are not available, a ball-park figure is 1,000 to 10,000 acres. Typical RCRA caps cost about $\$ 50 \mathrm{~K}$ to $\$ 300 \mathrm{~K}$ per acre. The prototype barrier constructed at Hanford is on the order of $\$ 300 \mathrm{~K}$ per acre. The total cost range is $\$ 50 \mathrm{M}$ to $\$ 30 \mathrm{~B}$. A realistic figure is a minimum of several billion dollars.

5. As operable units are closed, Hanford will face an immediate need for surface barriers. If DOE wants to begin closing out operable units within the next few years; it must have surface barrier technology ready to go. You are not, at this point, close to being ready to implement surface barriers on a massive scale.

6. For the sake of discussion, let's just assume that Hanford will spend $\$ 5 B$ over the next 20 years on surface barriers. The cost could easily go up or down 1,2 , or even $\$ 3 B$, depending on the final designs, components, thicknesses, etc. Once the surface barriers (graded to reflect the nature of underlying wastes) are selected, the same design will probably be repeated over and over. Hanford has an opportunity to spend several million dollars over the next several years to think through the surface barrier design, select and test the most cost-effective options, and then implement those options. This type of R\&D could lead to a 10 to 10,000 fold seturn on investment.

\section{PARALLELS TO EPA}

I have worked closely with EPA over the past 15 years and somewhat closely with DOE over the same period (especially the last 2 years). DOE is in danger of repeating EPA's mistakes in terms of surface barriers. The main points are:

\section{Mistakes that EPA made}

1. Underestimated the value of containment. The initial goal of full restoration of sites to pristine conditions turned out to be technically and economically impossible. EPA is now relying more on "containment" and "risk management," but these approaches are not well developed or verified.

2. Let their in-house containment capability slip. The result is that the expertise that EPA needs is largely' gone, except for one or two key people. The quality of regulations and oversight has suffered.

\section{Mistakes that DOE could make}

1. DOE has not put enough resources into containment technology and is likely to be in the position of needing technologies that are not yet proven or, in some cases, not available. The result is that, unless the situation is rectified, surface barriers will be selected that in many cases will not work. The cost to fix the problems could be enormous.

2. The Hanford group has people who have worked for several years or more on surface barriers. The DOE will need this expertise. A continuing commitment is needed to maintain a core group. 


\section{Appendix B}

\section{Permanent Isolation Surface Barrier Documents (Published to Date)}




\section{Appendix B}

\section{Permanent Isolation Surface Barrier Documents (Published to Date)}

1. Phillips, S. J., M. R. Adams, T. W. Gilbert, C. C. Meinhardt, R. M. Mitchell, and W. J. Waugh. 1985. Engineered Barrier Test Facility Status Report: 1984.

RHO-WM-SR-3P, Rockwell Hanford Operations, Richland, Washington.

2. Phillips, S. J., T. W. Gilbert, and M. R. Adams. 1985. Preliminary Engineering Specifications for a Test Demonstration Multilayer Protective Barrier Cover System. RHO-WM-EV-8 P, Rockwell Hanford Operations, Richland, Washington.

3. Fayer, M. J., W. Conbere, P. R. Heller, and G. W. Gee. 1985. Model Assessment of Protective Barrier Designs. PNL-5604, Pacific Northwest Laboratory, Richland, Washington.

4. Myers, D. R. 1985. Disposal Materials Study. RHO-WP-EV-12P, Rockwell Hanford Operations, Richland, Washington.

5. Adams, M. R., and M. F. Kaplan. 1986. "Marker Development for Hanford Waste Site Disposal." In Waste Management 1986, (Vol. 1), pp. 425-431, ed. R. G. Post. University of Arizona, College of Engineering and Mines, Tucson, Arizona.

6. Phillips, S. J., and J. N. Hartley. 1986. "Protective Barrier Systems for Final Disposal of Hanford Waste Sites." In Waste Management 1986, (Vol. 1), pp. 433-437, ed. R. G. Post. University of Arizona, College of Engineering and Mines, Tucson, Arizona.

7. Kaplan, M. F., and M. R. Adams. 1986. "Using the Past to Protect the Future: Marking Nuclear Waste Disposal Sites." Archeology 39(5):51-54.

8. Adams, M. R., and N. R. Wing. 1986. Protective Barrier and Warning Marker System Development Plan. RHO-RE-OL-35P, Rockwell Hanford Operations, Richland, Washington.

9. Fayer, M. J. 1987. Model Assessment of Protective Barrier Designs: Part II. PNL-6297, Pacific Northwest Laboratory, Richland, Washington. 
10. Last, G. V., M. A. Glennon, M. A. Young, and G. W. Gee. 1987. Protective Barrier Materials Analysis: Fine Soil Site Characterization. PNL-6314, Pacific Northwest Laboratory, Richland, Washington.

11. Gee, G. W. 1987. "Preliminary Analysis of the Performance of the Protective Barrier and Marker System." In Final Environmental Impact Statement, Disposal of Hanford Defense High-Level, Transuranic and Tank Wastes, Appendix M, DOE/EIS-0113, U.S. Department of Energy - Richland, Operations Office, Richland, Washington.

12. Kirkham, R. R., G. W. Gee, and J. L. Downs. 1987. Field Lysimeter Test Facility for Protective Barriers: Experimental Plan. PNL-6351, Pacific Northwest Laboratory, Richland, Washington.

13. Waugh, W. J., and S. O. Link. 1988. Barrier Erosion Control Test Plan: Gravel Mulch, Vegetation, and Soil Water Interactions. WHC-EP-0067, Westinghouse Hanford Company, Richland, Washington.

14. Wing, N. R., M. D. Campbell, J. L. Downs, G. W. Gee, R. R. Kirkham, and S. J. Phillips. 1988. "Protective Barrier Development: The Field Lysimeter Test Facility." In Proceedings of the International Topical Meeting on Nuclear and Hazardous Waste Management Spectrum 1988, pp. 196-198. American Nuclear Society, Inc., La Grange Park, Illinois, WHC-SA-0203-FP, Westinghouse Hanford Company, Richland, Washington.

15. Phillips, S. J., M. S. Ruben, and R. R. Kirkham. 1988. "Engineered Surface Barriers for Waste Disposal Sites: Lysimeter Facility Design and Construction." In DOE Model Conference Proceedings, pp. 1229-1238. CONF-881054. Oct. 3-7, Martin Marietta, Oak Ridge, Tennessee.

16. Ligotke, M. W. 1988. Soil Erosion Rates from-Mixed Soil and Gravel Surfaces in a Wind Tunnel: A Preliminary Report. PNL-6677, Pacific Northwest Laboratory, Richland, Washington.

17. Waugh, W. J., and M. G. Foley. 1988. Protective Barrier Climate-Change Impacts: Technical Workshop Findings and Recommendations. PNL-6615, Pacific Northwest Laboratory, Richland, Washington.

18. Ligotke, M. W. 1989. Surface Stability Test Plan for Protective Barriers. PNL-6722, Pacific Northwest Laboratory, Richland, Washington.

19. Gee, G. W., R. R. Kirkham, J. L. Downs, and M. D. Campbell. 1989. The Field Lysimeter Test Facility (FLTF) at the Hanford Site: Installation and Initial Tests. PNL-6810, Pacific Northwest Laboratory, Richland, Washington. 
20. Gee, G. W., M. D. Campbell, H. D. Freeman, and J. F. Cline. 1989. Assessment of Cover Systems at the Grand Junction, Colorado Uranium Mill Tailings Pile: 1987 Field Measurements. PNL-6762, Pacific Northwest Laboratory, Richland, Washington.

21. Petersen, K. L. 1989. The Long-Term Climate Change Assessment Task of the Hanford Site, Washington Protective Barrier Development Program. WHC-SA-0537-FP, Westinghouse Hanford Company, Richland, Washington.

22. Cadwell, L. L., L. E. Eberhardt, and M. A. Simmons. 1989. Animal Intrusion Studies for Protective Barriers: Status Report for FY 1988. PNL-6869, Pacific Northwest Laboratory, Richland, Washington.

23. Freeman, H. D., G. W. Gee, and J. F. Relyea. 1989. Field Study Plan for Alternate Barriers. PNL-6840, Pacific Northwest Laboratory, Richland, Washington.

24. Freeman, H. D., and G. W. Gee. 1989. Hanford Protective Barriers Program Asphalt Barrier Studies - FY 1988. PNL-6874, Pacific Northwest Laboratory, Richland, Washington.

25. Waugh, W. J. 1989. Gravel Admix, Vegetation and Soil Water Interactions in Protective Barriers: Experimental Design, Construction and Initial.Conditions. PNL-6616, Pacific Northwest Laboratory, Richland, Washington.

26. Freeman, H. D., and G. W. Gee. 1989. Hanford Protective Barriers Program: Status of Asphalt Barrier Study - FY 1989.. PNL-7513, Pacific Northwest Laboratory, Richland, Washington.

27. Link, S. O., and W. J. Waugh. 1989. Evapotranspiration Studies for Protective Barriers: Experimental Plans. PNL-6899, Pacific Northwest Laboratory, Richland, Washington.

28. Petersen, K. L. 1990. "The Long-Term Climate Change Assessment Task of the Protective Barrier Development Program for Low-Level Waste Site Remediation at the Hanford Site, Washington." In High Level Radioactive Waste Management, Vol 2, pp. 1235-1239. Proceeding of an International Topical Meeting. American Nuclear Society, La Grange Park, Illinois. (WHC-SA-0808-FP, Westinghouse Hanford Company, Richland, Washington).

29. Fayer, M. J. 1990. Test Plan for Hydrologic Modeling of Protective Barriers. PNL-7152, Pacific Northwest Laboratory, Richland, Washington.

30. Wing, N. R., and G. W. Gee (eds). 1990. Hanford Site Protective Barrier Development Program: Fiscal Year 1989 Highlights. WHC-EP-0318, Westinghouse Hanford Company, Richland, Washington. 
31. Campbell, M. D., G. W. Gee, M. J. Kanyid, and M. L. Rockhold. 1990. Field Lysimeter Test Facility: Second Year (FY 1989) Test Results. PNL-7209, Pacific Northwest Laboratory, Richland, Washington.

32. Landeen, D. S., L. L. Cadwell, L. E. Eberhardt, R. E. Fitzner, and M. A. Simmons. 1990. Animal Intrusion Field Test Plan. WHC-EP-0253, Westinghouse Hanford Company, Richland, Washington.

33. Link, S. O., M. E. Thiede, R. D. Evans, J. L. Downs, and W. J. Waugh. 1990. Evapotranspiration Studies for Protective Barriers: FY 1988 Status Report. PNL-6985, Pacific Northwest Laboratory, Richland, Washington.

34. Relyea, J. F., M. R. Sackschewsky, and W. J. Waugh. 1989. Small-Tube Lysimeter Facility Status Report for Fiscal Year 1989. WHC-EP-0297, Westinghouse Hanford Company, Richland, Washington.

35. Walters, W. H., K. A. Hoover, and L. L. Cadwell. 1990. Project Test Plan for Runoff and Erosion on Fine-Soil Barrier Surfaces and Rock-Covered Side Slopes. PNL-6791, Pacific Northwest Laboratory, Richland, Washington.

36. Hoover, K. A., L. L. Cadwell, and W. H. Walters. 1990. Hanford Protective Barriers Program: Water Erosion Studies - FY 1989. PNL-7214, Pacific Northwest Laboratory, Richland, Washington.

37. Landeen, D. S. 1990. Animal Intrusion Status Report for Fiscal Year 1989. WHC-EP-0299, Westinghouse Hanford Company, Richland, Washington.

38. Ligotke, M. W., and D. C. Klopfer. 1990. Soil Erosion Rates from Mixed Soil and Gravel Surfaces in a Wind Tunnel. PNL-7435, Pacific Northwest Laboratory, Richland, Washington.

39. Waugh, W. J., M. E. Thiede, C. J. Kemp, L. L. Cadwell, and S. O. Link. 1990. Field Study of Gravel Admix, Vegetation, and Soil Water Interactions: Protective Barrier Program Status Report - FY 1989. PNL-7440, Pacific Northwest Laboratory, Richland, Washington.

40. Hunter, C. R., A. J. Busacca, and W. J. Waugh. 1990. A Feasibility Study of Modeling Pedogenic Carbonates in Soils and Sediments at the U.S. Department of Energy's Hanford Site. PNL-7413, Pacific Northwest Laboratory, Richland, Washington. 
41. Wing, N. R., and G. W. Gee. 1990. "Protective Barrier Development: Overview." In Proceedings of the Twenty-Eighth Hanford Symposium on Health and the Environment, Environmental Monitoring, Restoration, and Assessment: What Have We Learned?, pp. 147-151, ed. R. H. Gray, Pacific Northwest Laboratory, Richland, Washington. WHC-SA-0619 FP, Westinghouse Hanford Company, Richland, Washington.

42. Wing, N. R., and G. W. Gee. 1990. "Protective Barrier Development: Overview." In Proceedings of the International Topical Meeting on.Nuclear and Hazardous Waste Management Spectrum 1990, pp. 335-337. American Nuclear Society, Inc., La Grange Park, Illinois. WHC-EP-0380, Westinghouse Hanford Company, Richland, Washington.

43. Glantz, C. S., M. N. Schwartz, K. W. Burk, R. B. Kaspar, M. W. Ligotke, and D. J. Perrault. 1990. Climatological Summary of Wind and Temperature Data for the Hanford Meteorology Monitoring Network. PNL-7471, Pacific Northwest Laboratory, Richland, Washington.

44. Campbell, M. D., and G. W. Gee. 1990. Field Lysimeter Test Facility: Protective Barrier Test Results (FY 1990, The Third Year). PNL-7558, Pacific Northwest Laboratory, Richland, Washington.

45. Sackshewsky, M. R., J. C. Chatters, S. O. Link, and C. A. Brandt. 1991. Protective Barrier Program: Test Plan for Plant Community Dynamics. WHC-EP-0380, Westinghouse Hanford Company, Richland, Washington.

46. Nichols, W. E. 1991. Comparative Simulations of a Two-Layer Landfill Barrier Using the Help Version 2.0 and UNSAT-H Version 2.0 Computer Codes. PNL-7583, Pacific Northwest Laboratory, Richland, Washington.

47. Landeen, D. S. 1991. Animal Intrusion Status Report for Fiscal Year 1990. WHC-EP-0398, Westinghouse Hanford Company, Richland, Washington.

48. Campbell, M. D., G. W. Gee, R. R. Kirkham, S. J. Phillips, and N. R. Wing. 1991. "Water Balance Lysimetry at a Nuclear Waste Site." In Proceedings of the International Symposium on Lysimetry, pp. 125-134, ed. R. G. Allen, American Soc. Civil Engr., New York.

49. Kirkham, R. R.; M. L. Rockhold, G. W. Gee, M. J. Fayer, M. D. Campbell, and L. J. Fritschen. 1991. "Lysimeters: Data Acquisition and Analysis." In Proceedings of the International Symposium on Lysimetry, pp. 362-370, ed. R. G. Allen, American Soc. Civil Engr., New York. 
50. Phillips, S. J., J. F. Relyea, C. J. Kemp, N. R. Wing, M. D. Campbell, G. W. Gee, M. J. Graham, R. R. Kirkham, and M. S. Rubin. 1991. "Development of Hanford Site Lysimeter Facilities." In Proceedings of the International Symposium on Lysimetry, pp. 19-27, ed. R. G. Allen. American Soc. Civil Engr., New York.

51. Waugh, W. J., M. E. Thiede, L. L. Cadwell, G. W. Gee, H. D. Freeman, M. R. Sackschewsky, and J. F. Relyea. 1991. "Small Lysimeters for Documenting Arid Site Water Balance." In Proceedings of the International Symposium on Lysimetry, pp. 151-159, ed. R. G. Allen. American Soc. Civil Engr., New York.

52. Cadwell, L. L. (ed) 1991. Hanford Site Protective Barrier Development Program: Fiscal Year 1990 Highlights. PNL-7831, Pacific Northwest Laboratory, Richland, Washington.

53. Petersen, K. L. 1991. Modern and Pleistocene Climatic Patterns in the West. WHC-EP-0523, Westinghouse Hanford Company, Richland, Washington.

54. Chatters, J. C., and H. A. Gard. 1991. Archaeological Mounds as Analogs of Engineered Covers for Waste Disposal Sites Literature Review and Progress Report. PNL-7718, Pacific Northwest Laboratory, Richland, Washington.

55. Sackschewsky, M. R., C. J. Kemp, L. L. Cadwell, M. E. Thiede, and W. J. Waugh. 1991. Status Report for the Small-Tube Lysimeter Facility Fiscal Year 1990. WHC-EP-0381, Westinghouse Hanford Company, Richland, Washington.

56. Fayer, M. J., M. L. Rockhold, and D. J. Holford. 1992. Model Assessment of Protective Barriers: Part III Status of FY 1990 Work. PNL-7975, Pacific Northwest Laboratory, Richland, Washington.

57. Petersen, K. L. 1992. A Warm and Wet Little Climate Optimum and a Cold and Dry Little Ice Age in the Southern Rocky Mountains, U.S.A. WHC-SA-1382-FP, Westinghouse Hanford Company, Richland, Washington.

58. Link, S. O., J. L. Downs, M. E. Thiede, D. J. Lettau, T. R. Twaddell, and R. A. Black. 1992. Evapotranspiration Studies for Protective Barriers: FY 1990 Status Report. PNL-8032, Pacific Northwest Laboratory, Richland, Washington.

59. Link, S. O., M. E. Thiede, J. L. Downs, D. J. Lettau, and W. J. Waugh. 1992. Evapotranspiration Studies for Protective Barriers: FY 1989 Status Report. PNL-8033, Pacific Northwest Laboratory, Richland, Washington. 
60. Fayer, M. J., M. L. Rockhold, and M. D. Campbell. 1992. Hydrologic Modeling of Protective Barriers: Comparison of Field Data and Simulation Results. Soil Sci. Soc. Am. J., 56:690-700.

61. Wing, N. R. 1992. A Peer Review of the Hanford Site Permanent Isolation Surface Barrier Development Program. WHC-MR-0392, Westinghouse Hanford Company, Richland, Washington.

62. Gee, G. W., M. J. Fayer, M. L. Rockhold, and M. D. Campbell. 1992. "Variations in - Recharge at the Hanford Site." Northwest Sci., 66:237-250.

63. Gee, G. W., M. D. Campbell, G. S. Campbell, and J. H. Campbell. 1992. "Rapid Measurement of Low Soil Water Potentials Using A Water Activity Meter." Soil Sci. Soc. Am. J., 56:1068-1070.

64. Ligotke, M. W. 1993. Soil Erosion Rates Caused by Wind and Saltating Sand Stresses in a Wind Tunnel. PNL-8478, Pacific Northwest Laboratory, Richland, Washington.

65. Fayer, M. J. 1993. Model Assessment of Protective Barriers: Part IV, Status of FY 1992 Work. PNL-8498, Pacific Northwest Laboratory, Richland, Washington.

66. Wing, N. R. and G. W. Gee. 1993. "The Development of Permanent Isolation Surface Barriers: Hanford Site, Richland, Washington, U.S.A." In Proceedings of Geoconfine '93, pp. 357-362. June 8-11, 1993, Montpellier, France. WHC-SA-1799-FP, Westinghouse Hanford Company, Richland, Washington.

67. Petersen, K. L., J. C. Chatters, and W. J. Waugh. 1993. Long-Term Climate Change Assessment Study Plan for the Hanford Site Permanent Isolation Barrier Development Program. WHC-EP-0569 Rev. 1, Westinghouse Hanford Company, Richland, Washington.

68. Wing, N. R. 1993. The Results of Laboratory Tests to Determine the Physical Properties of Various Barrier Construction Materials. WHC-SD-ER-DP-006, Westinghouse Hanford Company, Richland, Washington.

69. Gee, G. W., L. L. Cadwell, H. D. Freeman, M. W. Ligotke, S. O. Link, R. A. Romine, and W. H. Walters, Jr. 1993. Testing and Monitoring Plan for the Permanent Isolation Surface Barrier Prototype. PNL-8391, Pacific Northwest Laboratory, Richland, Washington.

70. Cadwell, L. L., S. O. Link, and G. W. Gee. 1993. Hanford Site Permanent Isolation Surface Barrier Development Program: Fiscal Year 1992 and 1993 Highlights. PNL-8741, Pacific Northwest Laboratory, Richland, Washington. 
71. Link, S. O., R. N. Kickert, M. J. Fayer, and G. W. Gee. 1993. A Comparison of Simulation Models for Predicting Soil Water Dynamics in Bare and Vegetated Lysimeters. PNL-8675, Pacific Northwest Laboratory, Richland, Washington.

72. Sackschewsky, M. R., C. J. Kemp, and L. L. Cadwell. 1993. Status Report for the SmallTube Lysimeter Facility Fiscal Year 1992. WHC-EP-0597, Westinghouse Hanford Company, Richland, Washington.

73. Petersen, K. L., and J. C. Chatters. 1993. Long-Term Climate Change Assessment Task for the Hanford Site Permanent Isolation Barrier Development Program: Status through FY 1992. WHC-EP-0644, Westinghouse Hanford Company, Richland, Washington.

74. Chamness, M. 1993. An Investigation of Bergmounds as Analogs to Erosion Control Factors on Protective Barriers. PNL-8841, Pacific Northwest Laboratory, Richland, Washington.

75. Bjornstad, B. N., and S. S. Teel. 1993. Natural Analog Study of Engineered Protective Barriers at the Hanford Site. . PNL-8840, Pacific Northwest Laboratory, Richland, Washington.

76. U.S. Department of Energy (DOE). 1993. Treatability Test Plan for the 200-BP-1 Prototype Surface Barrier. DOE/RL-93-27, Department of Energy, Richland, Washington.

77. Gee, G. W., D. Felmy, J. C. Ritter, R. R. Kirkham, S. O. Link, J. L. Downs, and M. J. Fayer. 1993. Field Lysimeter Test Facility: Status Report IV. PNL-8911, Pacific Northwest Laboratory, Richland, Washington.

78. Gaylord, D. R., L. D. Stetler, G. D. Smith, and R.W. Mars. 1993. Summary of 1990 Eolian Characterization Studies, Hanford Site, Washington. PNL-8862, Pacific Northwest Laboratory, Richland, Washington.

79. Wing, N. R. 1993. Permanent Isolation Surface Barrier: Functional Performance. WHC-EP-0650, Westinghouse Hanford Company, Richland, Washington.

80. Gilmore, B. G., and W. H. Walters. 1993. Warer Erosion Field Tests for Hanford Protective Barriers: FY 1992 Status Report. PNL-8949, Pacific Northwest Laboratory, Richland, Washington.

81. Kirkham, R. R. 1993. Comparison of Surface Energy Fluxes with Satellite-Derived Surface Energy Flux Estimates from a Shrub-Steppe. PNL-9003, Pacific Northwest Laboratory, Richland, Washington. 
82. U.S. Department of Energy (DOE) 1993. Report on Value Engineering Study of Permanent Isolation Surface Barrier and Warning Marker System Development Plan at the Hanford Site. DOE/RL/12074--8, Department of Energy, Richland, Washington.

83. Wing, N. R. 1994. Permanent Isolation Surface Barrier Development Plan. WHC-ẸP-0673, Westinghouse Hanford Company, Richland, Washington.

84. Waugh, W. J., J. C. Chatters, G. V. Last, B. N. Bjornstad, S. O. Link, and C. R. Hunter. 1994. Barrier Analogs: Long-Term Performance Issues, Preliminary Studies, and Recommendations. PNL-9004, Pacific Northwest Laboratory, Richland, Washington.

85. Link, S. O., L. L. Cadwell, C. A. Brandt, J. L. Downs, R. E. Rossi, and G. W. Gee. 1994. Biointrusion Test Plan for the Permanent Isolation Surface Barrier Prototype. PNL-9411, Pacific Northwest Laboratory, Richland, Washington.

86. Kirkham, R. R., and G. W. Gee. 1994. Experimental Plan and Construction Guidance for Hanford Protective Barrier Test at Hill AFB, Utah. PNL-9412, Pacific Northwest Laboratory, Richland, Washington.

87. Freeman, H. D., and R. A. Romine. 1994. Hanford Permanent Isolation Barrier Program: Asphalt Technology Test Plan. PNL-9336, Pacific Northwest Laboratory, Richland, Washington.

88. Link, S. O., W. J. Waugh, J. L. Downs, M. E. Thiede, J. C. Chatters, and G. W. Gee. 1994. "Effects of Coppice Dune Topography and Vegetation on Soil Water Dynamics in a Cold-Desert Ecosystem." J. Arid Environments 27:265-278.

89. Waugh, W. J., M. E. Thiede, D. J. Bates, L. L. Cadwell, G. W. Gee, and C. J. Kemp. 1994. "Plant Cover and Water Balance in Gravel Admixtures at an Arid Waste-Burial Site." J. Environ. Qual. 23:676-685.

90. Landeen, D. S. 1994. The Influence of Small Mammal Burrowing Activity on Water Storage at the Hanford Site. WHC-EP-0730, Westinghouse Hanford Company, Richland, Washington.

91. DOE. 1994. Constructability Report for the 200-BP-1 Prototype Surface Barrier. DOE/RL-94-76, U.S. Department of Energy, Richland Operations Office, Richland, Washington.

92. Myers, D. R., and D. A. Duranceau (eds). 1994. Prototype Hanford Surface Barrier: Design Basis Document. BHI-00007, Bechtel Hanford, Inc., Richland, Washington. 
93. Wing, N. R., and G. W. Gee. 1994. "Quest for the Perfect Cap." Civil Engineering 64(10):38-41.

94. Gee, G. W., and N. R. Wing (eds). 1994. In-Situ Remediation: Scientific Basis for Current and Future Technologies, Parts 1-2. Thirty-Third Hanford Symposium on Health and the Environment. November 7-11, 1994, Pasco, Washington. Battelle Press, Columbus, Ohio.

95. Wing, N. R., and G. W. Gee. 1994. "The Development of Surface Barriers at the Hanford Site." In In-Situ Remediation: Scientific Basis for Current and Future Technologies, Parts 1-2, pp. 427-440, eds. G. W. Gee and N. R. Wing, Thirty-Third Hanford Symposium on Health and the Environment. November 7-11, 1994, Pasco, Washington. Battelle Press, Columbus, Ohio.

96. Waugh, W. J., K. L. Petersen, S. O. Link, B. N. Bjornstad, and G. W. Gee. 1994. "Natural Analogs of the Long-Term Performance of Engineered Covers." In In-Situ Remediation: Scientific Basis for Current and Future Technologies, Parts 1-2, pp. 379-410, eds. G. W. Gee and N. R. Wing, Thirty-Third Hanford Symposium on Health and the Environment. November 7-11, 1994, Pasco, Washington. Battelle Press, Columbus, Ohio.

97. Freeman, H. D., and R. A. Romine. 1994. "Hanford Permanent Isolation Barrier Program: Asphalt Technology Development." In In-Situ Remediation: Scientific Basis for Current and Future Technologies, Parts 1-2, pp. 491-506, eds. G. W. Gee and N. R. Wing, Thirty-Third Hanford Symposium on Health and the Environment. November 7-11, 1994, Pasco, Washington. Battelle Press, Columbus, Ohio.

98. Gilmore, B. G., and W. H. Walters. 1994. "Summary of Method Develop a Representative Equation for Soil Loss from the Hanford Permanent Isolation Barrier." In In-Situ Remediation: Scientific Basis for Current and Future Technologies, Parts 1-2, pp. 507-522, eds. G. W. Gee and N. R. Wing, Thirty-Third Hanford Symposium on Health and the Environment. November 7-11, 1994, Pasco, Washington. Battelle Press, Columbus, Ohio.

99. Landeen, D. S. 1994. "The Influence of Small-Mammal Burrowing Activity on Water Storage at the Hanford Site." In In-Situ Remediation: Scientific Basis for Current and Future Technologies, Parts 1-2, pp. 523-544, eds. G. W. Gee and N. R. Wing, Thirty-Third Hanford Symposium on Health and the Environment. November 7-11, 1994, Pasco, Washington. Battelle Press, Columbus, Ohio.

100. Ligotke, M. W. 1994. "Control of Eolian Soil Erosion from Waste-Site Surface Barriers." In In-Situ Remediation: Scientific Basis for Current and Future Technologies, Parts 1-2, pp. 545-560, eds. G. W. Gee and N. R. Wing, Thirty-Third Hanford Symposium on Health and the Environment. November 7-11, 1994, Pasco, Washington. Battelle Press, Columbus, Ohio. 
101. Link, S. O., W. J. Waugh, and J. L. Downs. 1994. "The Role of Plants in Isolation Barrier Systems." In In-Situ Remediation: Scientific Basis for Current and Future Technologies, Parts 1-2, pp. 561-592, eds. G. W. Gee and N. R. Wing, Thirty-Third Hanford Symposium on Health and the Environment. November 7-11, 1994, Pasco, Washington. Battelle Press, Columbus, Ohio.

102. Myers, D. R., and N. R. Wing. 1994. "Hanford Site Protective Isolation Surface Barrier: Taking Research and Development to Engineered Application." In In-Situ Remediation: Scientific Basis for Current and Future Technologies, Parts 1-2, pp. 613-624, eds. G. W. Gee and N. R. Wing, Thirty-Third Hanford Symposium on Health and the Environment. November 7-11, 1994, Pasco, Washington. Battelle Press, Columbus, Ohio.

103. Petersen, K. L. 1994. "The Long-Term Climate Change Task of the Hanford Permanent Isolation Barrier Development Program." In In-Situ Remediation: Scientific Basis for Current and Future Technologies, Parts 1-2, pp. 633-648, eds. G. W. Gee and N. R. Wing, ThirtyThird Hanford Symposium on Health and the Environment. November 7-11, 1994, Pasco, Washington. Battelle Press, Columbus, Ohio.

104. Gee, G. W., H. D. Freeman, W. H. Walters, M. W. Ligotke, M. D. Campbell, A. L. Ward, S. O. Link, S. K. Smith, B. G. Gilmore, and R. A. Romine. 1994. Hanford Prototype Surface Barrier Status Report: FY 1994. PNL-10275, Pacific Northwest Laboratory, Richland, Washington.

105. Gaylord, D. R., and L. D. Stetler. 1994. "Aeolian-Climate Thresholds and Sand Dunes at the Hanford Site, South-Central Washington, U.S.A." J. Arid Environments 28:95-116.

106. Freeman, H. D., R. A. Romine, and A. H. Zacher. 1994. Hanford Permanent Isolation Barrier Program: Asphalt Technology Data and Status Report - FY 1994. PNL-10194, Pacific Northwest Laboratory, Richland, Washington.

107. Wing, N. R., G. W. Gee, and J. W. Cammann. 1995. "Program Management of a MultiYear Technology Development Effort." PM Network 9(3):47-50.

108. Duranceau, D. A. 1995. Site Evaluation Report for Candidate Basalt Quarry Sites. BHI-00005, Bechtel Hanford, Inc., Richland, Washington.

109. Rockhold, M. L., M. J. Fayer, C. T. Kincaid, and G. W. Gee. 1995. Estimation of Natural Ground Water Recharge for the Performance Assessment of a Low-Level Waste Disposal Facility at the Hanford Site. PNL-10508, Pacific Northwest Laboratory, Richland, Washington. 
110. Link, S. O., M. E. Thiede, R. D. Evans, J. L. Downs, and G. W. Gee. 1995. "Responses of Big Sagebrush and Spiny Hopsage to Increasing Water Stress." In Proceedings of the Wildland Shrub and Arid Land Restoration Symposium, pp. 196-201, eds. B: A. Roundy, E. D. McArthur, J. S. Haley, and D. K. Mann. USDA-FS, Intermountain Research Station, Ogden, Utah.

111. Wing, N. R., K. L. Petersen, C. Whitlock, and R. L. Burk. 1995. Long-Term Climate Change Effects Task for the Hanford Site Permanent Isolation Barrier Development Program: Final Report. BHI-00144 Rev. 00, Bechtel Hanford, Inc., Richland, Washington.

112. Wing, N. R., F. M. Corpuz, K. L. Petersen, and A. M. Tallman. 1995. Physical Stability of Long-Term Surface Barriers: Assessment of Potentially Disruptive Natural Events. BHI-00145 Rev. 00, Bechtel Hanford, Inc., Richland, Washington. 


\section{Distribution}

No. of

Copies

\section{OFFSITE}

12 DOE/Office of Scientific and Technical Information

C. S. Abrams

Argonne National Laboratory

P.O. Box 2528

Idaho Falls, ID 83401

J. Anderson

Idaho State University

Department of Biology

Pocatello, ID 83209

2 Battelle Memorial Institute

Project Management Division

505 King Avenue

Columbus, $\mathrm{OH} 43201$

ATTN: W. A. Carbeiner

Technical Library

M. Benge

Bechtel-FUSRAP

P.O. Box 350

Oak Ridge, TN 37830

R. D. Bennett

U.S. Army Engineer Waterways

Experiment Station

3909 Halls Ferry Road

Vicksburg, MS 39180-6199.

B. Bede

U.S. Ecology

509 E. 12th

Olympia, WA 98501
No. of

Copies

R. A. Black

Washington State University

Botany Department.

Pullman, WA 99164

R. R. Borish

West Valley Nuclear Service Company

P.O. Box 191

West Valley, NY 14171

4 Chem Nuclear Geotech

P.O. Box 14000

Grand Junction, CO 81502

ATTN: W. J. Waugh

A. T. Clark

U.S. Nuclear Regulatory Commission Division of Fuel Material Safety

Washington, D.C. 20555

D. E: Daniel

University of Texas

Dept. of Civil Eng.

Austin, TX 78712

2 Desert Research Institute

P.O. Box 60220

Reno, NV 89506

ATTN: J. T. Ball

S. W. Tyler

M. Dunkelman

Department of Health

Division of Radiation Protection

Airdustrial Park

BIdg. 5, M.S. LE-13

Olympia, WA 98504 
No. of

Copies

2 Foster Wheeler Environ.

1981 Snyder Rd.

Richland, WA 99352

ATTN: W. Riggsbee

R. L. Treat

3 Environmental Protection Agency

Hanford Project Office

712 Swift, MS B5-01

Richland, WA 99352

ATTN: D. A. Faulk

P. S. Innis

P. R. Beaver

S. Evans

U.S. Department of Energy

1580 Sawtelle Drive

Idaho Falls, ID 83403

L. G. Everett

Geraghty \& Miller, Inc.

5425 Hollister Ave., Suite 100

Santa Barbara, CA 93111-2346

F. T. Fong

U.S. Department of Energy

San Francisco Operations Office

1333 Broadway

Oakland, CA 94612

2 Hill Air Force Base

Environmental Management

Directorate

OO-ALC/EM

7276 Wardleigh Road

Hill AFB, UT 84056-5127

ATTN: B. Elliot

D. Stone

R. G. Hills

Department of Mechanical Eng.

New Mexico State University

Box 30001

La Cruces, NM 88003
No. of

Copies

7 Idaho National Engineering Laboratory

P.O. Box 1625

Idaho Falls, ID 83415

ATTN: J. E. Conner

J. Hubbell

M. A. Knecht

K. M. Kostelnik

D. L. McElroy

J. B. Sisson

Technical Library

4 Jacobs Engineering Group, Inc.

2155 Louisiana Blvd. NE \#1000

Albuquerque, NM 87110-5414

ATTN: T. Goering

M. Kyllo

J. Lommler

F. Titus

T. L. Jones

New Mexico State University

Agricultural Experiment Station

Box 3BF

Las Cruces, NM 88003

M. R. Jugan

U.S. Department of Energy

Oak Ridge Operations Office

P.O. Box E

Oak Ridge, TN 37830

W. A. Jury

University of California

at Riverside

Dept. of Soils

Riverside, CA 92502

D. Keefer

Illinois State Geological Survey

615 East Peabody Drive

Champaign, IL 61820 
C. Keller

SNL, Eastman Cherrington

P.O. Box 10129

Santa Fe, NM 87504

D. A. Knecht

Westinghouse Idaho Nuclear Co.

P.O. Box 4000

Idaho Falls, ID 83403

R. C. Letcher

U.S. Department of Energy

Morgantown Energy Technology Center

P.O. Box 880

Morgantown, WV 26505

4 Los Alamos National Laboratory

P.O. Box 1663

Los Alamos, NM 87545

ATTN: F. Barnes

K. V. Bostick

J. W. Nyhan

E. Springer

E. Maestas

U.S. Department of Energy

West Valley Project Office

P.O. Box 191

West Valley, NY 14171

C. Mascarenas

WINCO

P.O. Box 4000, MS 1572

Idaho Falls, ID 83404

C. Massimino

U.S. Environmental Protection

Agency

1200 Sixth Avenue

Seattle, WA 98101

S. Needler

EG\&G, Rock Flats

P.O. Box 464, Building 080

Golden, CO 80402
3 Oak Ridge National Laboratory

P.O. Box 2008

Oak Ridge, TN 37831

ATTN: G. Suter II

R. J. Luxmoore

E. D. Smith

3 Oak Ridge National Laboratory

P.O. Box Y

- Oak Ridge, TN 37830

ATTN: W. D. Burch

R. T. Jubin

D. T. Oakley

Waste Policy Institute

555 Quince Orchard Road

Suite 600

Gaithersburg, MD 20878

2 K. L. Petersen

207 Benham Street

Richland, WA 99352

C. Reith

Dyn McDermott Petroleum

Services

850 South Clearview Parkway

New Orleans, LA 70123

J. Rensel, MS PV-11

Washington State Department of Ecology

High-Level Waste Management

Olympia, WA 98504

G. N. Richardson

Hazen and Sawyer

4011 W. Chase Blvd.

Suite 500

Raleigh, NC 27607 
No. of

Copies

2 Sandia National Laboratories

P.O. Box $\mathbf{5 8 0 0}$

Albuquerque, NM 87185

ATTN: R. W. Lunch Technical Library

J. A. Shaffner

US Ecology

3855 Atherton Road

Suite 5

Rocklin, CA 95765

R. Shaw

Electric Power Research Institute

3412 Hillview Avenue

Palo Alto, CA 94304

S. D. Smith

University of Nevada-Las Vegas

Biology Department

Las Vegas, NV 89154

W. G. Spaulding

Dames and Moore

Suite 108

4220 S. Maryland Parkway

Las Vegas, NV 89119

M. J. Steindler

Argonne National Laboratory

9700 South Cass Avenue

Argonne, IL 60439

J. B. Stong

Gonzaga University

Civil Engineering Dept

E. 502 Boone

Spokane, WA 99258-0001

M. J. Sully

Reynolds Electric Engr.

Co. Inc., MS $966^{\circ}$

2626 Losee Road

Las Vegas, NV 89030
No. of

Copies

2 U.S. Department of Energy-

Albuquerque Operations Office

P.O. Box 5400, MS ERPO

Albuquerque, NM 87185-5400

ATTN: K. Bitner

G. J. Rael

2 U.S. Department of Energy

Savannah River Operations Office

P.O. Box A

Aiken, SC 29801

ATTN: W. J. Brumley

D. Bruegennjohann

3 U.S. Ecology

5333 Westheimer Rd.

Suite 1000

Houston, TX 77056-5407

ATTN: A. Palmer

L. D. Irwin

2 U.S. Geological Survey

$333 \mathrm{~W}$. Nye Lane

Carson City, NV 89706

ATTN: B. J. Andraski

D. E. Prudic

2 U.S. Geological Survey

Low-Level Radioactive Waste

Program

Water Resources Division

12201 Sunrise Valley Drive

Reston, VA 22092

ATTN: N. Trask

I. Winograd

3 U.S. Geological Survey

1201 Pacific Ave., Suite 600

Tacoma, WA 98402

ATTN: W. R. Bidlake

B. W. Drost

E. A. Prych

Distr.4 
No. of

Copies

3 U.S. Nuclear Regulatory Commission

Division of Engineering Safety

Waste Management Branch

5650 Nicholson Lane

Rockville, MD 29852

ATTN: T. J. Nicholson

E. O'Donnell

J. Kane

2 Washington State Department of Ecology

7601 W. Clearwater, Suite 102

Kennewick, WA 99336

ATTN: D. Teal

N. Uziemblo

2 Washington State Department of Ecology

Mail Stop PV-11

Olympia, WA 98504-8711

ATTN: E. M. Carlin

C. Cline

R. B. Hibbard

5 Washington State University Geology Department

Pullman, WA 99164

ATTN: A. J. Busacca

G. S. Campbell

D. Gaylord

K. Keller

P. J. Mehringer

E. P. Weeks

U.S. Geological Survey

Federal Center Mail Stop 413

Denver, CO 80225

M. Weishan

NYSERDA

P.O. Box 191

West Valley, NY 14171
No. of

Copies

10 Westinghouse Savannah River Company

P.O. Box 616

Aiken, SC 29802

ATTN: J. Cook

M. Flora

L. Huber

J. R. Knight

S. R. McMullin

E. Norton

M. J. Plodinec

C. T. Randall

E. Schiefer

M. G. Serrato

P. J. Wierenga

University of Arizona

Dept. of Soil \& Water

429 Shantz Building

Tucson, AZ 85721

\section{FOREIGN}

Prof. Johann Korkisch

Institute of Analytical Chemistry

University of Urnna

A-1090 Vienna

Wahringerstrasse 38

AUSTRIA

S. Melchior Institut für Bodenkunde der

Universität Hamburg

Allende-Platz 2, D-2000

Hamburg 13

FEDERAL REPUBLIC OF GERMANY

G. M. Smith

Intera Information Technologies

Chiltern House

45 Station Road

Henley-on-Thames

Oxfordshire RG9 1AT

UNITED KINGDOM 
No. of

Copies

12 DOE Richland Operations Office
J. J. Broderick
A7-27
R. D. Freeberg
A5-19
R. E. Gerton
A4-02
J. D. Goodenough
J. P. Hanson
A5-19
R. A. Holten
K8-50
H4-83
R. D. Izatt
A3-42
P. M. Pak
A5-19
A5-19
R. K. Stèwart
A5-90
D. E. Trader
S7-50
DOR-RL Reading Room 1

\section{ONSITE}

1 U.S. Army Corps of Engineers

$$
\text { W. L. Greenwald A5-20 }
$$

10 Bechtel Hanford Incorporated
M. A. Buckmaster ' H6-01
R. A. Carison H6-05
F. M. Corpuz
H4-85
T. A. Curran
H6-01
H. D. Downey
H4-84
C. E. Hodge
H4-82
M. J. Lauterbach
H4-91
D. R. Myers
H4-82
T. M. Wintczak
H4-92
J. G. Woolard
H4-89

4 Kaiser Engineers Hanford Company

C. C. Chamberlain G3-09

S. D. Consort

E6-31

D. L. Fort

E6-50

R. I. Watkins

E6-41
No. of

Copies

18 Westinghouse Hanford Company
M. R. Adams
H6-30
R. J. Bliss
B3-04
G. W. Jackson
H6-71
K. N. Jordan
S7-83
M. K. Korenko
B4-03
R. E. Lerch
S7-85
D. J. Newland
T7-37
R. W. Powell
G3-21
R. C. Roos
H6-30
W. A. Skelly
L4-69
J. C. Sonnichsen
H6-23
A. M. Tallman
H6-30
J. A. Voogd
G6-13
G. F. Williamson
G6-13
R. D. Wojtasek
S7-84
D. E. Wood
H6-30

Environmental Data Management Center (2)

35 Pacific Northwest Laboratory
K. A. Blanchard
K2-05
R. S. Davis
K9-33
J. L. Downs
K6-84
M. J. Fayer
K9-33
D. Felmy
K9-33
H. D. Freeman
P8-38
G. W. Gee (10)
K9-33
B. G. Gilmore
K9-33
P. C. Hays
K9-33
C. T. Kincaid
K9-33
R. R. Kirkham
K9-33
G. V. Last
K9-48
M. W. Ligotke (3)
P7-59
S. O. Link
K6-84
P. D. Meyer
K9-33
T. L. Page
K9-18
M. L. Rockhold K9-33 
No. of

Copies

R. A. Romine P8-38

M. R. Sackschewsky K6-84

Technical Report Files (5) 